Portland State University

PDXScholar

1979

\title{
Thought, word and deed in the mid-Tudor Commonwealth : Sir Thomas Smith and Sir William Cecil in the reign of Edward VI
}

Ann B. Clark

Portland State University

Follow this and additional works at: https://pdxscholar.library.pdx.edu/open_access_etds

Part of the Economic History Commons, and the European History Commons Let us know how access to this document benefits you.

Recommended Citation

Clark, Ann B., "Thought, word and deed in the mid-Tudor Commonwealth : Sir Thomas Smith and Sir William Cecil in the reign of Edward VI" (1979). Dissertations and Theses. Paper 2776.

https://doi.org/10.15760/etd.2772

This Thesis is brought to you for free and open access. It has been accepted for inclusion in Dissertations and Theses by an authorized administrator of PDXScholar. Please contact us if we can make this document more accessible: pdxscholar@pdx.edu. 
AN ABSTRACT OF THE THESIS OF Ann B. Clarke for the Master of Arts in History presented 18 May 1979.

Title: Thought, Word and Deed in the Mid-Tudor Commonwealth: Sir Thomas Smith and Sir William Cecil in the Reign of Edward VI.

APPROVED BY MEMBERS OF THE THESIS COMMITTEE:
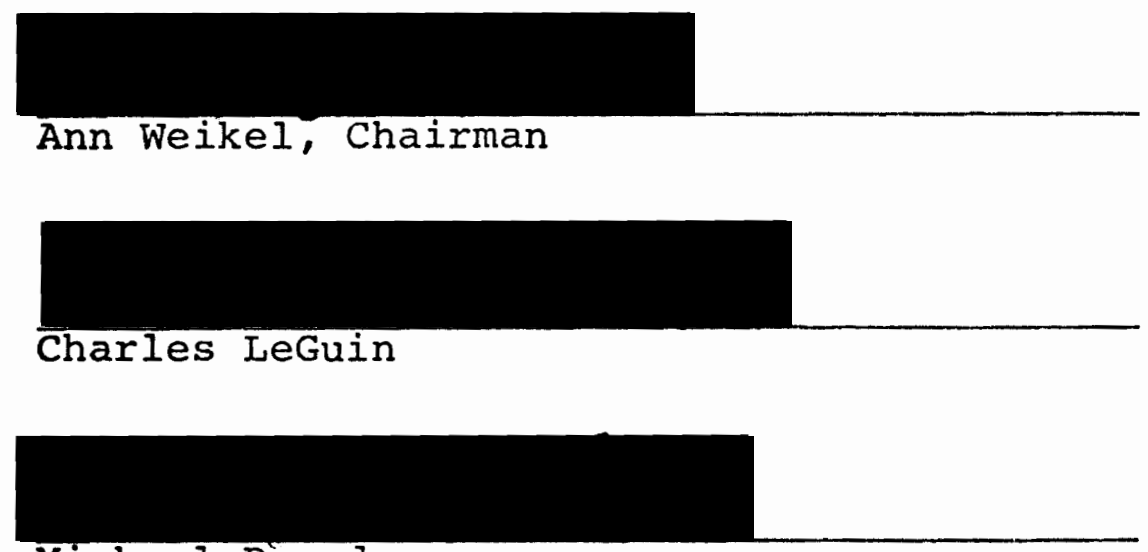

Michael Reardon

This thesis examines the general economic and intellectual climate of the mid-Tudor Commonwealth as a background for a specific study of the financial reforms instituted by Edward VI's government while the Duke of Northumberland controlled the Privy Council. The philosophy behind these measures parallels the principles expressed in A Discourse of the Commonweal of this Realm of England, a treatise written in 1549 by Sir Thomas Smith, Secretary to King Edward. In 1551-1552 the implementation of financial reform 
fell to Sir William Cecil, also King's Secretary and Northumberland's key administrator on the Council. In establishing the link between Smith's ideas and Cecil's policy, this thesis draws upon letters, Council records and Smith's written works to reveal the process by which thoughts became deeds in the mid-Tudor Commonwealth. 
THOUGHT, WORD AND DEED IN THE MID-TUDOR COMMONWEALTH SIR THOMAS SMITH AND SIR WILLIAM CECIL IN THE REIGN OF EDWARD VI

$$
\text { by }
$$

ANN B. CLARKE

\begin{abstract}
$A$ thesis submitted in partial fulfillment of the requirements for the degree of
\end{abstract}

MASTER OF ARTS

in

HISTORY

Portland State University

1979 
TO THE OFFICE OF GRADUATE STUDIES AND RESEARCH:

The members of the Committee approve the thesis of Ann B. Clarke presented 18 May 1979.
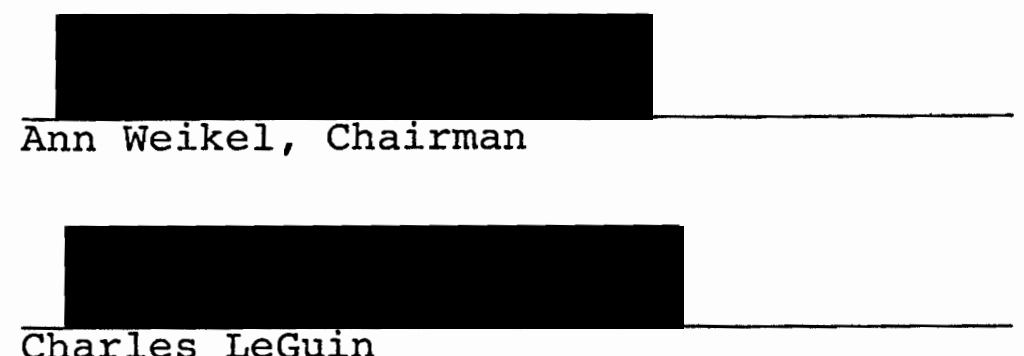

Charles LeGuin

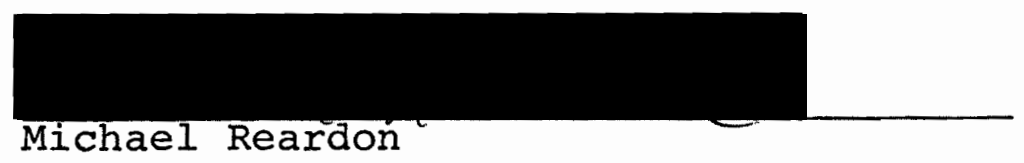

APPROVED :

Michael Reardon, Head, Department of History

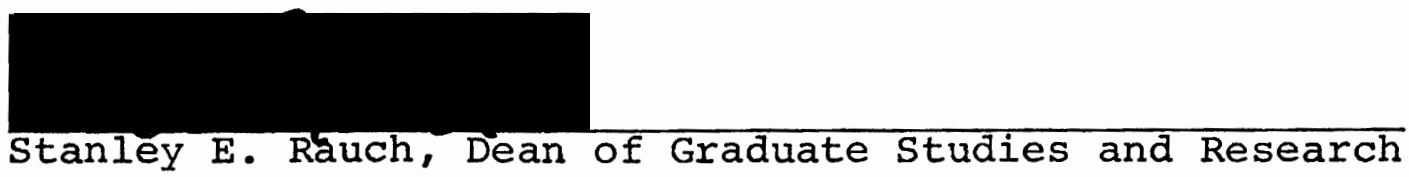




\section{PREFACE}

This thesis emerged from a study of Sir William Cecil and $\operatorname{Sir}$ Thomas Smith, statesmen who began their careers early in the reign of Edward VI. Familiarity with their activities, based on Smith's written works and official records of Cecil's Conciliar role, led to speculation about how the interplay of ideas between these two men may have influenced government policy during the mid-Tudor years.

In his Reform and Renewal, Professor Elton notes that the intellectual historians have studied complaints and prescriptions of mid-Tudor reformers, but that none has "attempted a systematic study of the way in which articulate protest and intellectual remedy-mongering may have percolated into statutes and proclamations; none is really concerned with the mechanism of translating aspiration into achievement." 1 This is Elton's launching pad for discussion of Thomas Cromwell's vision on its way to reality in the statute book. His suggestion can be transferred to the next generation of King's Secretaries. What impact did the reforms proposed by Smith, the scholar, have on the later policies of Cecil, the administrator? This thesis investigates the social and economic climate which prompted Smith,

${ }^{1}$ Geoffrey R. Elton, Reform and Renewal (Cambridge: Cambridge University Press, 1973), p. 6 . 
in 1549, to write his financial notions in A Discourse of the Commonweal of this Realm of England, suggests that his reforms bear a marked resemblance to those effected by Cecil in 1552, traces the course of his ideas into policy, and concludes that both Smith and Cecil influenced the reform of Edwardian finance more specifically than has previously been recognized. 
TABLE OF CONTENTS

Page PREFACE . . . . . . . . . . . . . . . . . $i i i$ ABBREVIATIONS . . . . . . . . . . . . . . . vii INTRODUCTION . . . . . . . . . . . . . . . . I Chapter

I HID-TUDOR HISTORIOGRAPHY INTRODUCTION . . . . . . . . . . . . 5 THE POLITICAL HISTORIANS . . . . . . • . 6 THE INTELLECTUAL HISTORIANS • • . • . • . 23 CONCLUSION • . . . . . . . . . . . . 26

II SIR THOMAS SMITH AND SIR WILIIAM CECIL • • • • . 27

III THE EDWARDIAN PRIVY COUNCIL . . . . . . . . 41

IV MID-TUDOR ECONOMIC PROBLEMS . . . • . . . . 53 INTRODUCTION . . . . . . . . . . . 53 INFLATION • . . . . . . . . . . 53 AGRICULTURE . . . . . . . . . . . . 60 FOREIGN TRADE ............... 63 INDUSTRY AND TOWNS .......... . 65 CONCLUSION . . . . . . . . . . . . 68

V MID-TUDOR COMMONWEALTH THOUGHT . . . . . . . 70

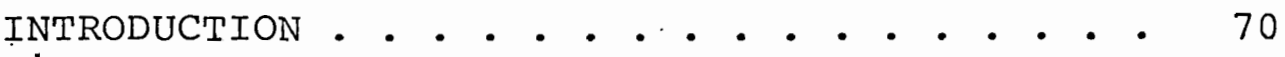

A DISCOURSE OF THE COMMONWEAL OF THIS

REALM OF ENGLAND . • . . . . • . . . • . 73

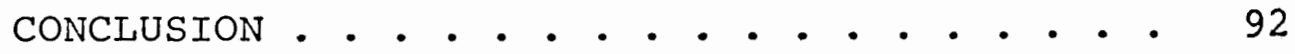


VI WILLIAM CECIL AND FINANCIAL REFORM

UNDER EDWARD VI • • • • • • • • • • • • • • • 94

INTRODUCTION . . . . . . . . . . . 94

SOURCES •. . . • . . . . . . . . . . 94

TUDOR REVENUE • • • • • • • • • • . . . . . 97

FINANCES UNDER SOMERSET . . . . . . . . 100

THE NORTHUMBERLAND YEARS $1550-1553 . . . . .104$

CONCLUSIONS . . . . . . . . . . . . 130

VII SMITH, CECIL AND FINANCIAL POLICY . . . . . . 133

CONCLUSION . . . . . . . . . . . . . . . . 142

BIBLIOGRAPHY . . . . . . . . . . . . . . 144

APPENDICES

I. DISCOURSE EXCERPT 1576 . . . . . . . . . . 153

II. SYNOPSIS OF "THE WAGES OF A ROMAN FOOTSOIDIER" •. . . . . . . . . . . 155

III. REVENUE COURT COMMISSION OF MARCH 23, 1552 . . . . . . . . . . 165 


\section{ABBREVIATIONS}
A.P.C.
Acts of the Privy Council
B.I.
British Library
Cal. Pat. Rolls, Edw. VI
Calendar of patent Rolls, Edward VI
Cal. S.P., Foreign
Calendar of State Papers, Foreign Series
Ec. H.R.
Economic History Review
H.M.C.
Historical Manuscripts
Commission
P.R.O.
Public Record Office
S.P.
State Papers 
INTRODUCTION

The six-year reign of King Edward VI coincides with the mid-Tudor Commonwealth, a period in which the insecurity of rapid change produced fresh analysis of the contemporary scene. The new breed of scholar-statesmen introduced by the Tudor monarchs brought the tradition of Erasmian humanism to Court where, through the Privy Council, they met the challenge of bringing the realm through a period of religious, political and socio-economic crisis. Sir Thomas Smith and Sir William Cecil were two such statesmen. Their Cambridge background and the career they shared as King's Secretaries successively under Edward VI contributed to a union of their disparate talents in the sphere of Crown finance.

Historians of the mid-Tudor period have identified ideas and events in this reign to construct theories of crisis and continuity. Attitudes and institutions, mature by 1600 , were being shaped at mid-century. These subjects of Tudor historiogaphy provide a context for a discussion of the Tudor century in general and the mid-Tudor Commonwealth in particular.

The careers of Sir Thomas Smith and Sir william Cecil exemplify participation in mid-Tudor Commonwealth reform. Men exposed to the "new learning," they saw in service to the state the means of enhancing the common weal and their 
personal fortunes. The careers they began as Secretaries under Edward came to fruition under Elizabeth, when Smith's brief Secretaryship followed Cecil's long development of that office. Although Smith and Cecil differed in their abilities and in the areas of their effectiveness, each made a contribution to Tudor history. Determining the point at which their activities converged gives focus to a study of the mid-Tudor Commonwealth.

Men and ideas need a vehicle to become effective in government. The mid-Tudor years were significant in the development of English governance, in the role of the Privy Council and the Secretaryship. Suppression of the council by the Duke of Somerset and later revitalization of its capacities by the Duke of Northumberland marked two periods of contrast in this short reign. The growth of the office of secretary echoed that of the council as routine duties were expanded into instruments of consequence.

Religious, political, social and economic developments during the first half of the sixteenth century produced a period of rapid change. In reaction, men's thoughts turned to creating a stable society free from turmoil. At midcentury this ideal was expressed in terms of a "Commonwealth," a model for the welfare of the realm which involved reconciling individual liberty with communal interest. Just as it had in the past, religion pervaded all aspects of intellectual activity. However, by the 1540s, Commonwealth 
literature emphasized the social and economic "griefs" from which men suffered. There was a universal desire for reform, but Commonwealth approaches to an improved society differed with men's motivations and their capacities to effect change. Just as the quality of Commonwealth literature was uneven, so individual statesmen varied in their contributions to government policy.

Financial reform became a necessity in Edward's reign. The inflation which characterized sixteenth century Europe was felt keenly in England where Henry VIII's military expenses had drained the treasury and the costs of government spiralled with commodity prices. Economic theory was in its infancy and few men could go beyond the statement of "manifold complaints" to the articulation of their causes and remedy. Sir Thomas Smith took this giant step in 1549 when he write the Discourse of the Commonweal of this Realm of England. It contained the economic principles which appeared in the financial reforms instituted by cecil late in Edward's reign. More specifically, Cecil's restoration of the fineness of English currency in 1552 reflected the fiscal expertise for which Smith was well-known. Their continuing relationship inside and outside the Council permitted the exchange of ideas which suggests that these parallels between theory and practice were not a matter of coincidence. Traditionally Cecil and Smith have been compared by the "juxtaposition of successful man of action and 
the failed man of letters." I Emphasis upon the area of their joint contribution restores the image of the "failed man of letters," gives credence to Cecil's early prominence and supports the Commonwealth concept that in the union of diversity comes the realization of the ideal. It gives substance to a study of thought, word and deed in the midTudor Commonwealth.

${ }^{1_{G}}$. R. Elton, Reform and Renewal (Cambridge: Cambridge University Press, 1973), p. 12 . 


\author{
CHAPTER I \\ MID-TUDOR HISTORIOGRAPHY
}

\title{
INTRODUCTION
}

Twentieth century scholars have shifted their traditional emphasis upon crisis to an increasing recognition of historical continuity. The pattern of their conclusions about specific events in the reign of Edward VI provides both historical and historiographical perspective. Political historians have centered their attention on the role of young King Edward and the circumstances which led to the ascendancy and demise of his key ministers--the Dukes of Somerset and Northumberland. Intellectual historians have analyzed the influence of humanism on sixteenth century thought. Differences of opinion regarding areas of crisis and continuity create a context for summarizing mid-Tudor historiography as it has emerged since 1900 .

Tudor historiography can, then, be approached on the basis of its emphasis. New evidence has forced the alteration of some "facts," or at least the interpretation of those facts, but for the most part, the events of the Tudor years stand firm in the history books. Historians have been led along divergent paths by the weight they have given to particular events. Most have agreed that the mid-century 
years witnessed political crises which threatened the Tudor dynasty. Modifying these tensions were the sinews of continuity--the English system of governance and a particular intellectual tradition. Both were essentially conservative, yet sufficiently flexible to accommodate change. Articulating these events and ideas occupied the Whig historians, their successors early in the century, and continue to challenge modern revisionists. Together their writing forms an historiographical complex in which political, religious and socio-economic conflicts can be identified against a background of stable English institutions and traditions. Just as the mid-sixteenth century was a transitional period, our own century has experienced changes which altered the writing of history. Outlining this evolution leads to a fuller understanding of men and events in both periods.

\section{THE POLITICAI HISTORIANS}

\section{A. F. Pollard}

Tudor historiography is dominated by A. F. Pollard. Publishing first in 1900, Pollard worked within the tradition of Victorian "scientific history," yet abandoned the multi-volume narratives of his predecessors, cited his sources in footnotes, and narrowed his field to the Tudor dynasty. His initial publication was England Under Protector Somerset. This was followed by numerous books on political and constitutional history, of which only The History of 
England - 1547-1603 pertains to this study. The last of the Whig historians, Pollard championed liberal ideas and progress, but was clearly an Edwardian in his character analysis and insight. His sensitivity to abrupt change reflected the shift in attitude which characterized the transition into the post-Victorian world. The conviction of his statements made Pollard's assessments of Tudor men and events the accepted standard until the 1950s.

Although Pollard broke with the tradition of narrative history, his fluid use of language placed him among those who wrote history as literature. He employed the artful turn of phrase, often as polemic, to create characterizations which have stuck. Rightly or wrongly, three generations of students have read of somerset the Good Duke and of Mary's "sterile" reign. The vigor with which Pollard is attacked by contemporary scholars is sufficient evidence of the power of his pen.

For Pollard the tensions of conflict fueled historical events. He described the mid-Tudor years as critical in the transition from the medieval era to the modern. Parliament vied with Crown for power, Catholics with Protestants. There was tension as Europe took the first steps toward a balance of power among emerging nation states. Between the determinative reigns of Elizabeth and her father were those of a little brother who did what he was told and an older 
sister whose "early promise soon withered away." I Faction within the Privy Council brought the demise of both Somerset and Northumberland and strangled policy under Mary.

As did Victorians generally, Pollard saw Henry VIII as a medieval despot whose last years undermined England's economic and political strength. 2 In creating a council of Regents to govern the realm during the minority of his son, Henry entailed his kingdom as a fee. ${ }^{3}$ Into this dismal picture stepped Edward Seymour, soon to be the Lord Protector and Duke of Somerset. Because of the depressed state of the realm he was to govern, Somerset's liberal policies had little chance to take effect. Iack of revenue and faction within the council forced somerset to act with one hand tied behind his back. Against great odds, this idealist accomplished a revolution in spirit. His two-year regime was a release from arbitrary government and an oasis of constitutional liberty. Somerset's policies were reversed by reactionary forces on the Privy Council led by the grasping Northumberland (then Earl of Warwick). Northumberland packed the council, interfered with Parliamentary elections,

$1_{\text {A. F. Pollard, The History of England 1547-1603 }}$ (London: Longmans, Green \& Co., 1923), p. 313 .

2A. F. Pollard, England Under Protector Somerset (Cambridge, 1900; rpt. New York: Russell \& Russel1, 1966), p. 38 .

${ }^{3}$ Pollard, History of. England 1547-1603, p. 2. 
cost England power and prestige by summarily ending the war with Scotland, brought finance to its nadir, and reintroduced arbitrary government by stiffening treason laws. He influenced Edward to alter the succession in favor of Lady Jane Grey in order to establish the Dudley dynasty. Pollard rarely mentioned Edward, whom he saw as a mere tool manipulated by his advisors. Throughout the reign, Privy Councillors were motivated by personal greed. Ultimately, seizure of power by Northumberland's faction enforced a policy "more repressive than that of Henry VIII, and abroad more spiritless and aimless than that of Mary." 4

While Pollard's analyses are too black and white for modern revisionists and his conclusions need new study, he did advance the writing of history.

G. R. Elton

G. R. Elton is today's premier Tudor historian. Since 1953, he has written prolifically on the political and constitutional aspects of the sixteenth century, concentrating upon the 1530s. The Henrician reforms of this decade, envisioned and accomplished by Thomas Cromwell, constitute Elton's revolution in government.

Elton's major historiographical influence has been to push the advent of modern political history back to 1471 . This is a shift from the traditional date of 1485 , the 
beginning of the Tudor era. He shows that by employing the reforms of Edward IV, Henry VII revitalized the ancient offices of the royal household and enhanced the power of the monarchy. This created a nucleus of advisors close to the king to supplement the state bureaucracy. Although this group traced its origin to the medieval Curia Regis, increased definition under Cromwell can be seen as a transitional step toward modern cabinet government.

Elton's name has become synonymous with Tudor revolution, a theme which also runs through Pollard's writing. Because he thinks in terms of conflict, Elton stresses crisis, faction and change. Such a context enables him to draw sharp contrasts. As did Pollard, Elton uses the dramatic element to enrich a sophisticated literary style.

The crises with which Elton is concerned are those of the succession from Henry VIII to Edward VI and the faction within the Privy Council during a reign fraught with economic and social disorder. The English constitution, in 1547, was still medieval in its need for a strong king. Thus crisis followed the accession of a minor. Like Pollard, Elton believes that "Edward played no part in his reign." 5 In fact, Elton is hard on this little "cold-hearted prig," just as he is on Edward's sister Mary. Elton sees these

${ }^{5}$ G. R. Elton, England Under the Tudors (London: Methuen \& Co., Ltd., 1955), p. 202 . 
two reigns as failures sandwiched between two periods of accomplishment. 6

The failure of this Edwardian era was due not only to the absence of a strong King, but to the inadequacies of his ministers, Somerset and Northumberland. Somerset, says Elton, showed no sign of administrative ability or political sense. 7 Nor was he able to sustain the support of his fellow Councillors. His incompetence made way for Northumberland, "a man for whom no one has ever had a good word." 8 Somewhat grudgingly, Elton does give Northumberland credit for facing the financial problems of his administration. He attributes the Duke's advancement of Protestantism solely to the material benefits which such a course would bring to the Dudley family. The threat of Mary's accession drove Northumberland to the "desperate and doomed" attempt to alter the succession, a plan which he persuaded Edward to endorse.

Over the years, Elton has moderated some of his harsher judgments. While not discounting the role of faction. in Edward's Council, Elton now qualifies his position on the overall failures of this reign. Still sounding the Cromwellian trumpet, he admits to a tinge of continuity in his

${ }^{6}$ G. R. Elton, The Tudor Revolution in Government (Cambridge: Cambridge University Press, 1969), p. 417.

${ }^{7}$ Elton, England Under the Tudors, p. 208.

${ }^{8}$ Elton, England Under the Tudors, p. 209. 
latest book, Reform and Reformation. The survival of government

- . Owed a good deal to Cromwell's administrative reforms which made possible a continuity in government that the older system had lacked, with its dependence on the personal activity of the king and his close helpers in the Household. . . The admin-9 istration ran on without a break or even a hiccough.

Such summary comments do injustice to an eminent historian. However, it is fair to say that in Reform and Reformation, Elton now acknowledges threads of administrative and ideological continuity which are ignored in his earlier work. Thus Elton is part of the gradual shift away from historiographical emphasis upon Tudor crises.

W. K. Jordan

W: K. Jordan devoted two lengthy volumes to the reign of Edward VI. Edward VI: The Young King appeared in 1968. Two years later it was followed by Edward VI: The Threshold of Power. The first volume is concerned almost entirely with religion; the second deals with religion, politics and the emerging influence of King Edward.

Jordan believes that a slow, peaceful Reformation was the key element in Somerset's policy. Somerset's was necessarily a temperate plan. Many powerful conservatives opposed radical religious reforms. The bishops themselves were divided and many of the secular clergy ignorant and

${ }^{9}$ G. R. Elton, Reform and Reformation (Iondon: Edward Arnold Publishers, Ltd., 1977), p. 338 . 
poor, making them inclined to conservatism or indifference. Against these forces, Somerset lacked the means for harsh enforcement. He had neither the money nor the full support of the Council necessary for firm action. Despite these impediments, Protestantism was firmly rooted in England by the time of the Protector's fall.

In Volume II, Jordan continues his discussion of the Reformation in the more radical policies of Warwick. The period following the Protectorate was one of reaction. The rebellions of 1549 made both Warwick and the Privy Council uneasy, and determined them upon a restoration of order. Jordan sees the trial and execution of somerset as the culmination of Warwick's efforts to end turbulence, although the ultimate result of these actions was a hardening of the anti-Warwick faction.

The most distinctive aspect of Jordan's thesis is his picture of Edward as the precocious child who, by the spring of 1550, was taking a real role in policy-making. ${ }^{10}$ He sees in Edward's writing evidence of the King's maturity and comprehension of affairs of state. Edward's tutors made a King by destroying a boy. Edward's primary concerns were maintaining the structure of royal power and the advancement of Protestantism. For these reasons, it was he who devised

${ }^{10}$ W. K. Jordan, Edward VI: The Threshold of Power (Cambridge, Mass.: The Belknap Press, 1970), p. 415. 
the scheme to alter the succession from Catholic Mary to Protestant Lady Jane Grey.

Jordan's Earl of Warwick is a brilliant, ruthless schemer. He was denied tyrannical power by lenient supporters of Somerset's policies who were still a force in the House of Commons. These proponents of Commonwealth reform were, however, a minority in the session of Parliament which ran during the winter of $1549 / 50$.

The structure of Warwick's power stood impressively complete in the third session of Parliament, because his personal convictions and philosophy of government coincided with the sentiments of men who had been badly frightened by the internecine disturbances of 1549 and the dangerous irresolution of the former Lord Protector in suppressing them. II

Once Warwick had established his position in the Council, he concentrated on consolidating his own power and bringing order to the realm. Aware of his own limitations, Warwick accepted the counsel of others and delegated responsibility. He was often away from London and "would sign any document approved by Cecil and others of the Council."12

With the exception of his new emphasis on the role of Edward, Jordan's analysis of the period follows the interpretation first put forth by Pollard. Jordan's enhancement of Edward's historical stature is based on his study of Edward's notebooks.

${ }^{11}$ Jordan, Threshold of Power, p. 44.

12 Jordan, Threshold of Power, p. 36 . 
B. L. Beer

To date there is no comprehensive biography of John Dudley, Viscount Lisle, Earl of Warwick, Duke of Northumberland. Barrett Beer's Northumberland, published in 1973, focuses on the Dudley family, its ascendancy and the consequences of that rise.

Beer does, however, make some points of interest in the historiographical assessment of Edwardian personalities. He believes that the "device" to alter the succession was Northumberland's idea, a conclusion supported by all but Jordan. However, for Beer Northumberland's plan was almost noble, certainly not Machiavellian, for it was most dangerous to the Duke personally. He risked all on the scheme and did so for the cause of Protestantism and the future security of his family.

Beer also touches on administrative history. In 1552 and 1553 the King and secretary Petre joined forces to reorganize the work of the Privy Council. ${ }^{13}$ Time ran out before most of the reforms could be implemented, but this fact should not detract from the "heroic measures" of Northumberland and his associates to invigorate the administrative system. $^{14}$ While not denying Northumberland's

${ }^{13}$ Barrett $I$. Beer, Northumberland (The Kent State University Press, 1973), p. 144. Dale Hoak has since demonstrated that Northumberland began Council reform in 1550, following suggestions made by William Paget. See Hoak, The King's Council in the Reign of Edward VI, p. 38. 
influence on reform, Beer sees these measures as coming from Edward. In this he is supported by Jordan. Beer's Northumberland plays the role of the good physician attempting to cure the ills of the body politic by seeking a Parliamentary subsidy in the spring of 1553, all other attempts to raise revenue having failed. Beer questions Northumberland's understanding of Tudor taxation through Parliamentary grant, but credits him with "turning to the right body for financial remedy. " 15

Since Beer's biography deals only slightly with policy, its significance in this discussion must not be equated with the work of Bush and Hoak. An all-encompassing study of Northumberland would give needed dimension to the historiography of Edward's reign.

M. L. Bush

Michael L. Bush published The Government Policy of Protector Somerset in 1975. His style is straightforward and clear, as are his stands on issues, He begins by saying that his purpose is "to demolish an interpretation erected by A. F. Pollard and renovated latterly by W. K. Jordan" and to offer a new political study of Edward's reign. 16 Bush relies on the letters of Sir William Paget to establish

${ }^{15}$ Beer, Northumberland, p. 145.

${ }^{16}$ Michael L. Bush, The Government Policy of Protector Somerset (London: Edward Arnold Publishers, Ltd., 1975), p. vii. 
his thesis that Somerset's preoccupation with garrisoning Scotland and Ireland determined his fate and that of his government. There is no hint of a "good" Duke in Bush's Somerset, a man of conservative, fixed ideas who used the guise of $\mid$ clemency to achieve his own ends.

Bu\$h argues that somerset justifiably earned a great reputation as a soldier under Henry VIII. It was therefore to be expected that somerset, as a successful military man and uncle of the Prince, would rise quickly under King Henry and be ready to assume a position of prominence under King Edward.

Bush explains Somerset's policy in terms of his obsession for war with Scotland, a plan contingent upon garrisons. Garrisons were also the basis for his Irish policy. Ireland had been an area of insurrection under Henry and was to remain expensive and troublesome. The immense cost of the scottish war and the continuing expense of garrisons designed for permanent subjection dictated the rest of Somerset's action. It forced him to exploit all sources of revenue and to cut costs wherever possible. His problem was aggravated by the depleted treasury left by Henry VIII. Somerset's program was not visionary and radical as portrayed by Pollard, but purely pragmatic. Far from being revolutionary, Somerset's regime was conservative, aimed at maintaining the status quo. He in fact sought to prevent change and to preserve a hierarchy which would 
support Tudor government.

In the Council, too, Bush sees Somerset as observing the old forms. The Council secretaries performed only the routine duties of correspondence and service on investigative commissions, a far more restrictive position than that enjoyed by the Secretary of the 1530s. Under Somerset, and also under Northumberland, the Privy Council was enlarged and its procedure formalized, but it experienced no extension of power. As Elton's student, Bush echoes Elton's assessment of the Council in The Tudor Revolution in Government. 17 Nor does Bush see any novelty in Somerset's desire to extend national sovereignty or statutory competence. ${ }^{18}$ Somerset's image as the Good Duke was the result of his conscious effort to gain support of the Commons, in essence a propaganda ploy attempted by a man who at heart entertained traditional aristocratic views.

Bush, then, is among the revisionist historians seeking to dispel the Pollard tradition of abrupt change. In his new assessment of Somerset and his policies, Bush reverses Pollard's conclusions about the man and his philosophy. In stressing the conservative nature of Somerset's goals and

\footnotetext{
p. 415 .

${ }^{17}$ G. R. Elton, The Tudor Revolution in Government,

${ }^{18}$ Somerset hoped to claim suzerainty over scotland. To this end he set Sir Thomas Smith, a Secretary of the Council, upon an investigation of England's legal position in this matter.
} 
the position of the Council during his tenure, Bush makes these years of Edward's reign ones in which historical continuity predominates.

D. E. Hoak

In 1976 Dale E. Hoak published The King's Council in the Reign of Edward VI, the most authoritative study of Edwardian administrative history to date. Hoak accepts the fact of acute governmental crisis during this reign. The survival of the Tudor dynasty and the English system of governance he ascribes to Northumberland's utilization of a Privy Council sufficiently developed in its capacity and procedure to carry out the functions of government during a minority.

In examining the operation of the Edwardian Privy Council, Hoak contrasts the administration of Edward's key statesmen, the Duke of Somerset and the Duke of Northumberland. Hoak's thesis is that somerset failed to use the Privy Council, and that he acted unilaterally and ineffectively. The weakness of his administration aroused the enmity of his fellow Councillors who feared for the welfare of the realm and therefore instigated his downfall. Somerset's regime contrasts sharply with that of Northumberland. Hoak describes the latter as an administratively successful period during which Northumberland systematized procedures, followed the advice of his capable Privy Councillors and allowed them to administer the policies of the realm. Hoak 
attributes the success of the second half of Edward's reign to Northumberland's revival of Privy Council formulation of policy and his utilization of the board as an effective instrument of implementation. The essential continuity of English governmental institutions not only survived political crisis, but also was the factor which made that survival possible.

Hoak had access to Sir William Paget's Letter Book, a source unknown to Pollard. This provided him with documentation for his contention that somerset did not heed his Councillors' advice. Paget not only warned Somerset about a loss of confidence among his colleagues in the Council, but also offered concrete suggestions which somerset ignored. Sir Thomas Smith's proposals fell on the same deaf ear. Hoak counters the Pollard tradition of Somerset the Good Duke who, though his regime was a failure, deserved praise for his liberal ideas and lenient government in the wake of Tudor despotism. Hoak has little interest in moral judgments. It matters not to him whether an avaricious statesman is good or bad. Hoak focuses his attention upon statesmen's approaches to government and the effectiveness of their policies.

Hoak makes several points. Like Elton, he views Edward as having little or no impact on government. He acknowledges that at age fifteen Edward was perhaps a precocious administrator, but contends that even so he was no 
more than a puppet in the hands of his ministers. Thus the Literary Remains in which Jordan sees mature ideas for procedural reform are for Hoak mere schoolboy exercises prepared under the supervision of Councillors, usually Cecil. Because he was King, Edward's favor had to be nurtured. Council meetings were often staged for his benefit. However, Edward did not interfere with the appointment of Privy Councillors under either Somerset or Northumberland. This allowed them full control of the Council by determining its membership.

As mentioned above, Hoak shows that Somerset ignored advice. He contrasts Northumberland's employment of able Councillors, using Cecil for illustration. Just as Gates and Darcy were Northumberland's men in the King's household, so Cecil was Northumberland's man in the Council. The Duke was often. sick and did not attend Council meetings. As Secretary, Cecil was the central element in the council, coordinating its business and organizing its administration. Hoak suggests that from September 1551 until July 1553 Cecil played a key role in Northumberland's government. Recognition of Cecil's importance in this reign is a significant contribution to political and administrative history. Elton concurs with this judgment in his latest book.

Hoak investigates two central questions in his study: why Somerset tore up the provisions of Henry's will with respect to the membership of Edward's Council, and why 
Northumberland (then Earl of Warwick) moved so suddenly after the coup d'etat (1549) to cast his lot with the leftwing reformers. 19 Hoak's answers rest on control of the Privy Council. Somerset realized that control depended upon determining its membership through the power of appointment. As a member of a body of executors deriving power from the deceased King, Somerset was but one among equals. As Protector, Letters Patent gave him the royal prerogative power of appointment upon the authority of the present king. In exercising his capacity to control the Council's membership, he assumed supremacy over it. Although he chose not to become Protector, Northumberland's motives were the same. He did not go through the legal steps of acquiring appointment power. However, the King, the Council and the Lord President simply proceeded to act as if he had done so. Thus Northumberland manipulated the Council's membership to ease out the conservative element and ultimately formed a dominant faction of Protestants. Hoak's implication is clearly that both men recognized the importance of the Privy Council and understood that to rule they must seize control of it. The contrasts in their subsequent utilization of the board is the basis for Hoak's assessments of Somerset and Northumberland.

The thrust of Hoak's argument is that in the Privy

${ }^{19}$ Dale E. Hoak, The King's Council in the Reign of Edward VI (Cambridge: Cambridge University Press, 1976), p. vii. 
Council English governance possessed an instrument which allowed it to survive the reign of a king who was weak because he was a child. The personal element in government remains crucial, however; for effective use of this institution required a capable administrator. In Northumberland himself, and in Northumberland's exploitation of Cecil's talents, the Privy Council's traditional capacity to function was revived. Once again it offered advice and originated policy, implemented this policy and acted in a quasi-judicial manner by handling investigations and funneling petitions to proper courts.

Continuity is the underlying theme of Hoak's comprehensive study of the Edwardian Council. Once again the harsh outlines of conflict and crisis have been softened by emphasis on the stable elements of English governance.

\section{THE INTELLECTUAL HISTORIANS}

During the sixteenth century, England experienced both Renaissance and Reformation. Inherent in these movements was a rush of intellectual development, one aspect of which can be called Commonwealth thought. Although they are but part of a larger group, three intellectual historians represent current work on English reformist thought. Arthur Ferguson, James McConica and W. R. D. Jones take England out of her customary insular position and examine English humanism in a European context. Using the teaching of 
Erasmus as their link, these scholars emphasize the continuity of sixteenth century ideas. They too differ in their approaches and special interests, but as a group intellectual historians attach more significance to the evolutionary development of reformist ideas than to breaks within the pattern.

\section{James McConica}

McConica equates English humanism with Erasmianism. Like Ferguson, McConica brings humanism from Italy, through Erasmus, to Sir Thomas More and Cambridge and so to the statesmen who served Henry VIII and Edward VI. Although the Edwardian generation of "new men" inclined toward Protestantism, the influence of Erasmus supported a continuity of thought by striving for humanist values within the medieval Christian context. That both Catherine of Aragon and Catherine Parr were adherents of Erasmus is evidence that opinions could differ within Christian unity. Indeed the concept of a united Christendom, impliçit in More's Utopia, underscores the pan-European aspect of humanism for McConica.

W. R. D. Jones

The thrust of Jones' study is on the social and economic problems of the Commonwealth, as exemplified by "poverty and his cousin necessity," "the naughtiness of the silver" and "Mr. Avarice and Lady Public Weal." Jones treats only the period 1529-1559 and narrows his focus to 
the impact of contemporary English development on contemporary English thought. Jones, too, is of the continuity school. He sees a conservative, medieval element throughout the period in the Commonwealth assumption that dissent would break the social fabric and bring rebellion. Divine sanctioning of the social order, an acceptance of this hierarchy by all men of learning and the belief that religious reform and socio-economic amelioration go hand in hand are characteristic of both medieval and Commonwealth thought. In this way, Jones explains the general reaction throughout the sixteenth century to the disorder of the fifteenth and the specific reaction under Northumberland to the rebellion under somerset.

\section{Arthur B. Ferguson}

In contrast to Jones' brief period of concentration, Ferguson considers two centuries of intellectual development. Still within the evolutionary context, Ferguson sees a change in thought emerge in Commonwealth literature at midcentury. The Renaissance characteristics of focus and perspective enabled sixteenth century humanists to observe and describe social and economic change in a manner far more sophisticated than that of their predecessors, who employed the medieval analogy of the ailing body politic. For Ferguson, the contribution of the humanists between 1525 and 1550 was their attempt to create a rational and virtuous society. Though they failed, they brought fresh insight 
into the society in which they were living. ${ }^{20}$ Ferguson recognizes Sir Thomas Smith's unique position in this articulate group as a scholar and statesman who was also the author of the Discourse of the Commonweal of this Realm of England. This treatise, says Ferguson, is a statement of humanist methods and assumptions which remained to the end of the century virtually without rival and justifies the Tudor faith in the informed mind. 21

\section{CONCLUSION}

The works of political and intellectual historians together reveal a pattern of ideological continuity amidst social, economic, political and religious crisis. The reform measures attempted late in the reign of Edward VI demonstrate the application of humanist training to economic problems, the translation of aspiration into achievement.

\footnotetext{
${ }^{20}$ Arthur B. Ferguson, The Articulate Citizen and the English Renaissance (Durham: Duke University Press, 1965), p. 199 .

${ }^{21} 1_{\text {Ferguson, Articulate Citizen. }}$
} 


\section{SIR THOMAS SMITH AND SIR WILLIAM CECIL}

The financial reforms undertaken by King Edward's government in 1551 and 1552 illustrate how the exchange of ideas can influence policy. When Sir William Cecil assumed responsibility for these measures, he turned for advice to Sir Thomas Smith, his friend and colleague. Associates since their Cambridge days in the 1530s, Smith and Cecil shared a background which nurtured their relationship and bore significantly upon their careers as Privy Councillors under Edward VI and Elizabeth.

Sir Thomas Smith was born in 1513 to a minor gentry family-in Essex. The elder Smith was a small sheep farmer who must have sacrificed to send his eleven year old son to Cambridge. After just two years with a tutor, young Thomas precocity enabled him to enter Queen's College, at the time second in prestige only to St. John's. Erasmus had been in residence at Queen's and, as a result, the scholars there were noted for their fresh approach to the classics and confidence in the mind of man. ${ }^{l}$ This tradition shaped the thought of Thomas Smith who, with his friend John Cheke,

$I_{W}$. S. Hudson, John Ponet, Advocate of Limited Monarchy (Chicago: University of Chicago Press, 1942), p. 5 . 
earned rapid academic promotion and recognition as a humanist. Smith's thorough study of the classics, particularly Greek, added much to his later writings, his sense of Iiterature, his historical perspective and his methodology. His exceptional ability earned him appointment as King's Scholar in 1527, Fellow of Queen's College in 1530, Lecturer in Greek in 1533, Public Orator of the University in 1538, Regius Professor of Civil Law in 1540 and Vice-Chancellor of the University of Cambridge in 1543. Later, Waltex Haddon said of Smith that he had infused life into every branch of study in the University and, like St. Paul, had been "all things to all men." 2

Sir William Cecil was born in Lincolnshire in 1520 to a prosperous gentry family. Cecil's father was a member of Henry VIII's Court and his wife's money had enabled him to acquire property near stamford. The Cecils were becoming members of the "new aristocracy," and it was fitting that their son be sent to Cambridge.

By the time Cecil entered St. John's College in 1535, Thomas Smith was well along in his academic career. However the two soon became acquainted. Cecil was John Cheke's student and lived in Cheke's house until 1541, when his father removed him to Gray's Inn to study law. While at Cambridge, Cecil also studied the classics and enjoyed the companionship of Cheke, Smith and their friends Roger Ascham, 
John Ponet and Anthony Cooke. The close association of these men made Cambridge the center of academic excellence and stimulating conversation. Erasmus' new pronunciation of Greek was enthusiastically debated. Religious reform was in the air, and discussions sharpened the thought of all who participated. As religion spilled over into politics, these exchanges may well have contributed to the concept of limited monarchy which appears in the later writings of both Smith and Ponet. ${ }^{3}$

The six years following Gardiner's ascendancy at Cambridge in 1542 brought the gradual departure of this group of young men. They left because the conservative Gardiner was hostile to their new ideas, because they leaned toward Protestantism, and because government service was becoming a recognized means of getting ahead. Cheke, Ascham and Cooke went to court as tutors for Edward and Elizabeth. ${ }^{4}$ The effect of these humanist scholars upon Edward was significant

\section{${ }^{3}$ John Ponet's A Short Treatise of Politike Power}

(1556) justifies rebellion against a monarch who breaks the oath of honorable government. An example of such a breach would be forcing a "false" religion upon his (her) subjects. Thomas Smith's De Republica Anglorum (1565) also supports the right of citizens to rebel against tyrannical government. Both were considered extreme statements when they were written.

\section{${ }^{4}$ Erasmian emphasis upon the proper education of a} prince as a means of "reformation," or return to simple piety, appealed to Catherine Parr, who brought the Cambridge scholars to court as tutors for the royal children. This is the channel through which McConica sees the influence of Erasmus continued. See: J. K. McConica, English Humanists and Reformation Politics Under Henry VIII and Edward VI (Oxford: Clarendon Press, 1965), p. 261 . 
for Edward became a convinced Protestant. When Smith and Cecil arrived at Court in 1547, they came not as members of Edward's household, but in Somerset's service, at a time when the Duke's control of the government made a position in his household more significant than one in Edward's Council. From this beginning, Smith and Cecil moved into their political careers.

Within a month after his arrival at Court, Smith's training in civil law prompted somerset to make him clerk of the Privy Council. 5 As clerk, Smith learned Council procedure and was called upon to give legal advice. ${ }^{6}$ In March 1547, Smith was also made Somerset's master of requests, a household position through which the Duke entertained minor

${ }^{5}$ Dewar, Sir: Thomas Smith, p. 26.

${ }^{6}$ Between February 1547 and October 1549, Smith served on various commissions in his capacity as a civil lawyer. In the spring of 1547, he was a member of a commission investigating Northampton's divorce and also prepared a detailed report for Somerset regarding England's possible sovereignty over Scotland. His first mission abroad took place during the summer of 1548, when he went to Antwerp to investigate merchants' grievances and report on a possible war between France and the Low Countries. For an account of this mission, see Smith to Cecil, 6 July 1564, S.P. Elizabeth, $70 / 73 / 546$, f. 462. During January and February 1548/9, Smith conducted interrogations of William Sharington and Thomas Seymour regarding fraud at the Bristol mint. This procedure involved Smith's questioning of Princess Elizabeth regarding her relationship with Thomas Seymour. Although known as a financial expert, smith did not serve on any revenue commission during Edward's reign. 
suits. ${ }^{7}$ Smith enjoyed this dual capacity for about a year, a period he spent improving his own fortunes and performing valuable services for the government. These efforts were rewarded on April 16, 1548 when he was named second Secretary to King Edward, succeeding William Paget. ${ }^{8}$ Smith held this position until october, 1549.

Willaim Cecil remained in Somerset's service throughout the Protectorate. He served as the Duke's personal secretary and followed Smith as master of requests in the spring of $1548 .{ }^{9}$ Although Cecil had no official government position, his proximity to Somerset gave him real power. All men seeking access to the Duke approached him through Cecil. Thus from the beginning of his career, Cecil inspired the confidence of rulers and handled suitors with discretion, talents which later enabled him to become the crucial link between Crown and Council. under Edward and Elizabeth. In the summer of 1549, their careers began to diverge with a shift in the relative importance of Smith and Cecil. This presaged their ultimate effectiveness in the government. Smith lost favor with the Duke of Somerset in June and was required to remain in Eton, where he had been Provost of the

7 The court of requests established by somerset should not be confused with the government's Court of Requests, a formal court with its own set of records. p. 183 .

${ }^{8}$ Dewar, Sir Thomas Smith, p. 32. See also A.P.C., II, ${ }^{9}$ Dewar, Sir Thomas Smith, p. 27. 
College since 1547. While in "exile" away from Court, Smith tried to advise somerset through Cecil, who remained the Duke's confidant. 10

Both Smith and Cecil were sent to the Tower after the Duke of Somerset fell from power in October 1549, but were released the following spring. Smith had lost his Secretaryship in the October coup d'etat and did not hold office again in Edward's reign. Although seven years older than Cecil and Cambridge's most distinguished scholar, Smith had to be content with short-term assignments which he probably owed to Cecil. Cecil, on the other hand, survived the year of rivalry between Somerset and the Earl of Warwick and was named King's Secretary in September 1550. When Warwick's control of the Council was secure a year later, cecil began the expansion of the Secretaryship which was to be the mark of his career. 11

Cecil's importance in the reign of Edward VI has been overlooked by historians. 12 However, Dale Hoak's recent study of the Edwardian Privy Council now prompts him to conclude that "if anyone set national financial policy under

${ }^{10}$ Smith to Cecil, 19 July 1549, S.P. Edw. VI, 10/8/33. ${ }^{11_{\text {For }}}$ evidence of the range of Cecil's activities, see S.P. Edw. VI $10 / 14$ and $10 / 15$.

${ }^{12}$ Even Conyers Read, Cecil's biographer, offers little for this period. 
Northumberland it was probably Cecil."13 Elton agrees with Hoak. ${ }^{14}$ Although neither Elton nor Hoak develops the Cecilian role, some documentation for such a project exists. Beginning late in 1551, the letters recorded in the Calendar of State Papers, Foreign, 1547-1553 show a sudden increase in the number addressed specifically to cecil. Cecil had, of course, been Secretary since October 1550, so this shift was not due to his position as secretary. The same persons writing to cecil in 1552 had previously addressed their correspondence to the council in general. Thus we can conclude that Cecil's position of importance after October 1551, was generally acknowledged. The ambassadorial letters in the Calendar of State Papers, Spanish follow somewhat the same pattern. Writing to the Queen Dowager on Christmas Day 1552, Jehan Scheyfve referred to Secretary Cecil, "who is the Duke of Northumberland's man." 15 Among the memoranda contained in the state papers Domestic, Edward VI are the notebook pages in Cecil's hand showing the range of his activities and suggestions for solving financial problems. ${ }^{16}$ Among the few records

13 Hoak, Dale E., The King's Council in the Reign of Edward VI (Cambridge: Cambridge University Press, 1976), p. 212 .

${ }^{14}$ Elton suggests Cecil's importance only in his latest book, Reform and Reformation (1977).

${ }^{15}$ Calendar of State Papers, Spanish, X, p. 610. ${ }^{16}$ S.P. Edw. VI, $10 / 5$ f. $149-50 ; 10 / 14$ f. $53 ; 10 / 15$ f. $17-124$. 
autographed by Cecil cited in the H.M.C. Salisbury Manuscripts for Edward's reign are two, dated October 2, 1552, on the subject of the King's debt and "the devise to paye the dett."17 Cecil's influence upon the king is clear from the documents printed in the Literary Remains of Edward the Sixth which Cecil composed with Edward. ${ }^{18}$ Lastly, the Acts of the Privy Council show a pattern of increased Council attendance by cecil after October 1551, except for the few occasions of his famous and well-timed illnesses. Council records are too impersonal to shed real light on Cecil's activities, but when combined with other fragments of information, are a guide to the subject matter with which the Council was concerned. Thus Cecil's emergence in Edward's reign could well be the subject of a fruitful historical investigation.

In addition to the use of sources, the influence.which Cecil exerted on administrative reform can be discerned through retroductive reasoning, that useful practice of which historians must be wary. Hindsight, however, does enable one to move from the known to the unknown. Cecil's development of the Secretaryship under Elizabeth is fully documented and his position as the Queen's great minister well known. A careful approach to problems, a habit of and 396. H.M.C. Salisbury Manuscripts, I, p. 99, nos. 395 ${ }^{18}$ see below, p. 96. 
presenting both sides of each issue, the ability to grasp the broad spectrum of government policy and the deft management of personalities characterize Cecil, the Elizabethan statesman. A knowledge of this later period enables one to see the same traits developing in the younger cecil during Edward's reign. Cecil brought to this secretaryship the same talent for administration which matured under Elizabeth. The firm hand which directed the balancing of Edward's budget was the same one which rectified the coinage early in Elizabeth's reign.

Although Smith was not a member of the Privy Council in the latter part of Edward's reign, his participation on various religious commissions and diplomatic embassies kept him close to the Court. His friendship with Cecil was one of the longest and suffered fewer tensions than any other in Smith's lifetime. ${ }^{19}$ Smith had an arrogant manner, a genius for alienating people, and such insensitivity that he was surprised to discover that acquaintances did not like him. 20 He was also blindly loyal, a virtue which proved to be a political liability. Smith's definite opinions, freely offered, probably account for the fact that his political

${ }^{19}$ John G. Nichols, "Some Additions to the Biographies of Sir John Cheke and Sir Thomas Smith," Archaeologia, No. $38(1860)$, p. 110. Nichols cites a period of tension between Smith and Cecil in 1562 .

${ }^{20}$ Smith to the Duchess of Somerset, July/August 1549. B.L. Harleian MS. 6989, f. 141 . 
career never matched his expectations. Throughout his life, Smith's various proposals were so bluntly stated that they offended the people whom they were designed to convince. That Cecil stood by his crusty friend for forty years testifies to the strength of their bond and to Cecil's recognition of Smith's attributes. Among these was his remarkable mind, a resource upon which Cecil drew.

The careers of Smith and Cecil cannot be equated in terms of their success. However, the paths they followed were close. Their friends, their interests and their government service brought them into frequent contact during the reigns of both Edward and Elizabeth. 21 This association led to an exchange of ideas between Smith and Cecil and to their joint impact upon government policy.

While Cecil's Elizabethan career has been explored, his Edwardian years need more study. 22 Smith, on the other hand, has been overlooked by history, his contributions masked by anonymity and his abilities recognized by few. At Cambridge, Smith distinguished himself in the study of theology, philosophy, civil law, astronomy, mathematics and chemistry and he read six languages. His knowledge of

${ }^{21}$ Smith and Cecil shared an interest in coins. Smith refers to an occasion when the two had inspected certain coins in Cambridge. See Appendix II.

${ }^{22}$ Conyers Read, Lord Burghley and Queen Elizabeth (London: Jonathan Cape, 1960) and Mr. Secretary Cecil and Queen Elizabeth (New York: Alfred Knopf, 1955). 
medicine was considerable and guided his brewing of various potions, one of which he sent to Cecil's daughter to prevent a miscarriage. Smith diagnosed his own throat cancer, devised a procedure to remove the growth and was dismayed to find no surgeon willing to undertake the radical procedure. ${ }^{23}$ His interest in architecture developed into a true passion. The beautiful house which he designed and built in Essex in the late 1560s still stands. It is distinguished by two orders of attached columns as well as other late Renaissance features. Nikolaus Pevsner's comments about Hill Hall somehow describe all the areas of Smith's accomplishment. "The motif is, as far as I know, unique in England, and has for that reason been so baffling to scholars as to make them attribute it to a much later date."24 Just as he used classical details in his architectural designs, Smith's writing shows an easy familiarity with classicai languages and literature. These various interests were represented in his library, perhaps the finest of the period. Smith gave his books to Queen's College at his death; unfortunately, almost all have disappeared.

Smith's written works also exhibit the wide range of his knowledge. Most were published posthumously. His

${ }^{23}$ Dewar, Sir Thomas Smith, p. 186.

24 Nikolaus Pevsner, "Hill Hall," Architectural Review (May 1955), p. 307. 
papers on the new pronunciation of Greek and revised English alphabet date from his Cambridge days, but were not published until 1568. The Discourse of the Commonweal of this Realm of England was written in 1549, revised by Smith in 1576, and published only after his death in 1581. De Republica Anglorum, which Frederic Maitland considered the finest description of mid-sixteenth century English government, was written in 1565 and published in 1583. In 1562, at the request of Cecil, Smith wrote a treatise on "The Wages of a Roman Footsoldier," which has never been published. 25 Among the irritants Queen Elizabeth attributed to Smith was his Dialogue on the Queen's Marriage (1561), in which he cited the dangers inherent in the Queen's single state, problems which could be overcome by her marriage to Leicester. Some mournful translations of the Psalms and some very bad poetry date from Smith's period of confinement in the Tower, the winter of 1549/50. At that time, Smith's interest turned to astrology, a "science" which continued to fascinate him throughout his 1ife. In 1571, Smith was busy with a plan for establishing "plantations" in Ireland. Sir James Croft had experimented with such a project off and on since 1548, so Smith cannot be credited with originating the concept of colonization. His ideas, however, "do state for the first time arguments which later became the standard schemes of

${ }^{25}$ Sir Thomas Smith, "The Wages of a Roman Footsoldier" (B.I. Addit. MS. 48087). See Appendix II for synopsis. 
colonial promoters."26 As was true of so many of Smith's plans, the settlement of Ireland failed, and Smith's only son died along with Smith's hopes to make Ireland a lucrative colony for the Queen.

Smith's spasmodic political career is complemented by a general lack of recognition for his written work. 27 Until recently, only De Republica Anglorum had received the scholarly appreciation Smith's achievements deserve. Thanks to the work of Mary Dewar, Smith is now the acknowledged author of the Discourse of the Commonweal of this Realm of England and is considered a possible author of the "Memorandum 'For Understanding the Exchange'," long attributed to Sir Thomas Gresham. 28 Smith's competence as a numismatist is clear from reading his still unpublished treatise on Roman coins. Smith was a scholar of dimension, a Renaissance man. It

${ }^{26}$ David B. Quinn, "Sir Thomas Smith (1513-1577) and the Beginnings of English Colonial Theory," Proceedings of the American Philosophical Society, 89, No. 4 (December 1945), pp. 543-60.

${ }^{27}$ Smith served as Secretary to King Edward from March 1548 to October 1549 and as Queen Elizabeth's Principal Secretary from 1572 to 1576. He spent the interval between these secretaryships in short term posts. For example, he was ambassador to France from 1562 to 1564 and he received the Order of the Garter for his successful embassy to France in 1572. See Dewar, Sir Thomas Smith, p. 145.

${ }^{28}$ Mary Dewar, "The Memorandum 'For Understanding the Exchange: its Authorship and Dating," Ec.H.R. 17 (1965), pp. $388-400$. 
remains to bring the full impact of his accomplishments into the light of day.

Thomas Smith and William Cecil shared a background and a career. Their many years of continuous contact led to a cross fertilization of ideas which germinated in the financial policies of the last two Edwardian years. The arena for this activity was the Privy council. 


\section{CHAPTER III}

\section{THE EDWARDIAN PRIVY COUNCIL}

The financial reforms of 1551 and 1552 were effected through the Privy Council, that vehicle for the formulation and implementation of policy so vital to Tudor government. Here William Cecil emerged as a chief advisor and realized the aspirations of Thomas Smith. Since the careers of Smith and Cecil were affected by the same circumstances which controlled the productivity of the Council in Edward's reign, discussing the position of the board at mid-century illuminates the different impacts made by these two secretaries. The Edwardian Privy Council traced its origin to the Curia Regis, the inner circle of nobles obligated to advise the medieval king upon request. The board owed its modern institutional history to the Cromwellian reforms of the 1530s which had transformed a fluid body, subject to royal whim, into a more compact unit with permanent membership, lines of procedure and a broadening scope of responsibility. The evolution begun in the reign of Henry VIII was completed in that of Elizabeth. The two short reigns which intervened lacked the leadership of a strong monarch, making the survival of the Tudor dynasty contingent upon the performance of the Privy Council. Thus the role of the council had both administrative and political consequence. 
The reign of Edward VI is a unique period in the history of the Council. Within a six-year period, the board first existed in form only, while its energies lay fallow, and was then resurrected to a level of activity which rescued the English system of governance and the Tudor heritage. During the Protectorate, the Council stood ready to serve but was not called upon because somerset chose to rule alone. Under Northumberland, Privy Council procedures were revitalized, and once again its capacity to originate and implement policy was utilized. Somerset ignored advice and by-passed the Council. Northumberland sought expert counsel and restored Conciliar function. At this time, the personal element remained a determinative factor in English government. The board had begun its modern phase, but its utility was still proportional to the quality of the direction it received, whether from monarch or from minister.

The growth of the office of secretary coincided with the development of the Privy Council. It, too, reached fruition under Elizabeth. Just as the effectiveness of the Council depended upon good leadership, so the Secretaryship could be exploited by a competent minister. ${ }^{1}$ The first

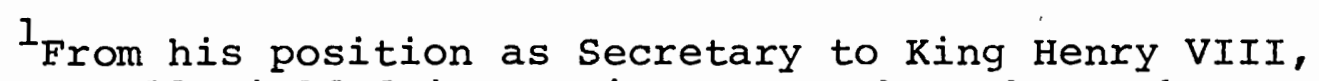
Thomas Cromwell wielded increasing power throughout the decade of the 1530s. The undefined nature of the office enabled him to achieve a measure of independence which threatened Henry, causing the King to divide the office between two officials in 1540. See F. M. Evans, The Principal Secretary of State (New York: Barnes and Noble, Inc., 1923), p. 33 . 
Edwardian years constituted a period of Conciliar quiescence, during which the secretary performed only routine duties. This was followed by two years when governance through the Council achieved some measure of stability in a turbulent reign. Northumberland provided the overall political strength to control the Council while transferring administrative responsibility to secretary Cecil. Together, they wielded political and administrative power to direct the Privy Council's formulation and implementation of policy. Because he shared power with Northumberland, who exercised formal leadership of the Council, Cecil's role as Secretary cannot be equated with Cromwell's. However, Cecil's varied activities during this period were a prelude to those under Elizabeth, when he came to prominence as her Principal Secretary. The secretaryship in the Edwardian era was the bud which bloomed in the 1560s.

The contrast between the regimes of somerset and Northumberland provide a context in which to identify some specific characteristics of the Council under Edward. In all areas of Conciliar activity, a pattern emerges of increased procedural definition. The lax enforcement of ill-conceived policies under Somerset was reversed by Northumberland's comprehensive approach to planning and the expediency which guided his policies into action through the Council. Dale Hoak bases his assessment of these two ministers upon the effectiveness of their leadership of the 
Council, concluding that Somerset's tenure was one of administrative failure and Northumberland's one of accomplishment. Contrasting the two periods of Edward's reign reveals a basic difference in attitude toward the Council between the Protector and the Lord President. Somerset employed the Council only as a rubber stamp for his own ideas. The Northumberland years brought procedural development in record keeping, in the use of committees, in the authorization of directives and in the preparation of agendas and regularization of meeting days. Definition in these areas enhanced the Council along Cromwellian lines, giving it the instrumentation to carry out government policy.

Council records reflect this evolutionary pattern. Somserset often bypassed regular Council meetings with secret conferences which were preserved in memory only. ${ }^{2}$ When council minutes were kept, the dates and contents were sometimes altered expeditiously. Not until the Northumberland era do sources for Council activity become reliable. Docquets were then signed by Councillors and endorsed by either of the two Secretaries. Various memorials of Council business reveal that it was Cecil who preserved the official . documents which show the functioning of the council and the latitude of the Secretaryship during the eighteen months of

2 Dale E. Hoak, The King's Council in the Reign of Edward VI (Cambridge: Cambridge University Press, 1976), p. 17 . 
his greatest activity. ${ }^{3}$

Somerset hid the autocratic nature of his rule under the official guise of Privy Council signatures on letters, proclamations, warrants and registers. Throughout the Protectorate, the number of signatures was flexible, though delicate matters usually carried many names in order to create an image of full Council compliance. Somerset legally possessed royal power through Letters Patent and, according to the Tudor oath, each Councillor could indeed act in the King's name. Therefore, it was not strictly necessary to secure additional signatures on these official documents. Somerset, however, was very sensitive to criticism and required Councillors to give evidence of their support by signing warrants. Northumberland, by contrast, ruled with equally effective power, but shifted the semblance of power to Edward. Proclamations ceased to bear the Council's endorsement and were signed by the King, although in reality they had been created in Council. This procedure concealed the ruling hand of Northumberland and flattered Edward who, by 1551, was eager for participation in his government.

A similarly revealing change occurred in the Privy Councillors' signatures on warrants for payment. Somerset operated under the assumption that Councillors appointed by

$$
{ }^{3} \text { Hoak, The King's Council, p. 29. See also S.P. }
$$
Edw. VI $10 / 5 \mathrm{f} . \frac{144-8 \text { and } 10 / 14 \mathrm{f} .}{115-22}$. 
him shared his autocratic power. Accordingly warrants often went out bearing the signatures of only a few councillors. There was no Council seal to indicate full board responsibility, the endorsement being binding. To tighten control of finances, Northumberland obtained Letters Patent from Edward which specifically authorized "every privy councillor and at least six of them to address warrants over their own signatures only to the treasurers and receivers of the king's revenue courts." 4 This established a hierarchy of responsibility from the Council to Northumberland and constituted another step toward procedural definition and centralization of authority.

Council administration was carried out by the two Secretaries who were key, though ex-officio, members of the board. 5 They set the agenda and handled all correspondence and, as a result, were the best informed ministers. When combined with the position they enjoyed as liaisons to the King and to Parliament, this capacity created a potential for great administrative influence. Cecil, the junior secretary from October 1550, at first assumed the routine duties of his office. These soon multiplied because Principal Secretary Petre was often away from Court.

\section{${ }^{4}$ Hoak, The King's Council, p. 147 .}

5 Although they served the Council, the secretaries were actually members of the King's Household in this transitional period and for this reason were not considered official members of the Council. 
Northumberland, too, delegated responsibility to Cecil, so that during the last eighteen months of Edward's reign, the junior secretary was in fact the effective executive and administrative officer of the council. These were the conditions which allowed him to develop his own potential and that of the secretaryship.

Under Somerset, Council members had little influence. Thus, a Council composed of able ministers could produce only still-born ideas. Official papers, private letters and memoranda all indicate that somerset himself controlled the topics which were to be discussed at Council meetings. In this way, he barred discussion of controversial subjects and averted criticism. The secretary did not, therefore, lead the course of Council business under Somerset, nor was he given a voice in determining policy. In April 1549, William Paget: prepared a.list of matters to be resolved in Council. 6 He also proposed that the board meet on a regular basis three or four times each week, that pertinent matters be discussed frankly in these meetings and that records of Council business be kept in an orderly fáshion. In like manner, Sir Thomas Smith conducted an investigation into possible sources of revenue. This was a thorough study of a desperate situation which smith detailed in a letter to

${ }^{6}$ Camden Miscellany, Volume XxV (London: The Royal Historical Society, 1974), p. 30 . 
Somerset in June $1549 .^{7}$ Somerset acted on neither minister's recommendations, to the detriment of government policy and morale within the Council. Somerset's vacillation and leniency meant that few comprehensive policies were envisioned or enforced.

The pattern changed abruptly when Northumberland assumed power in October 1549. Northumberland was not only decisive, he recognized that he was not infallible and that he would profit from expert advice on specific aspects of governance. As a soldier, Northumberland knew how to control men. However, his experience did not extend to the inner workings of governmental institutions or to the problems of financing a system in which expenditure exceeded revenue. From the Somerset experience, Northumberland realized that his own position would be enhanced by support of an efficient Council through which policies could be wisely determined and carried out. Hoak believes that Northumberland began the reform of the Council in the spring of 1550. He believes also that these measures resulted from the "Advice" submitted at that time by Paget to secretary Petre, who later formalized existing practice in his own "Articles" of $1553 .^{8}$ The regularization of Council business and procedure resulted from Northumberland's recognition of

${ }^{7}$ Smith to Somerset, 22 June 1549, S.P. Edw. VI 10/7/38, f. 96 .

${ }^{8}$ Hoak, The King's Council, p. 164. 
sound policy. He had the wisdom to use good advice to strengthen both his own position and Edward's government in improving Privy Council function.

The constant need for money throughout Edward's reign forced both Somerset and Northumberland to concentrate on sources of extraordinary revenue. Their contrasting utilization of the Council to solve financial problems highlights their individual philosophies and the two eras of council activity

From the beginning of Edward's reign, Paget attempted to counsel somerset on both foreign and domestic matters. As an experienced and energetic Councillor, Paget gave serious consideration to finance, which he believed to be central to all aspects of government policy. In other words, "the Protector's ability to finance his programmes in any one field rested upon his ability to finance his programmes in every field." 9 paget spoke plainly: "youe are in beggerye, in debt . . " 10 somerset ignored this warning, made no study on which to base a request for Parliamentary subsidy in 1548, and rejected Smith's assessment in

$$
\begin{aligned}
& { }^{9} \text { Hoak, The King's Council, p. } 167 . \\
& { }^{10} \text { Hoak, The King's Council, p. } 170 \text {. Cites Paget to }
\end{aligned}
$$
Somerset, 25 December 1548/49. N.R.O. Fitzwilliam (Milton) MS. C 21. See summary in Camden Miscellany, Volume XXV, p. 19 and modernized text in Huntington Library Quarterly, Volume XXXIV' (May 1971), 'pp. 277-83. 
1549. ${ }^{11}$ However, commissions assigned by somerset to investigate the revenue sources and mints were composed of Privy Councillors and operated with some measure of success. ${ }^{12}$ This effective use of the Council is exceptional in Somerset's regime. The pattern of the Protector's financial activity is one of short-term solutions to immediate problems, the result of somerset's stubborn refusal to heed Conciliar advice. The full story of Edwardian finance is yet to be written, but evidence exists to mark distinct policy changes under Northumberland. 13

Northumberland agreed with Paget that policy was tied to finance. After he seized power in October 1549, he took immediate steps to curtail expenses. No doubt influenced

${ }^{11}$ In this letter Smith advises Somerset to call in old debts, sell additional Crown lands and, as a desperation measure, debase some additional coinage. This was a careful evaluation of revenue sources, and although it offered nothing new Smith's plan was designed to give the most relief at the least cost to the realm. Somerset paid no attention to Smith's advice.

12 There were many commissions throughout Edward's reign directed to investigate financial matters. One appointed on July 21, 1547 was composed of Sir Walter Mildmay, Sir Ralph Sadler, Sir Edmund Peckham and Sir William Sharington. They were to audit the accounts of the Tower Mint and report on the amount of silver and gold contained there. Another in September 1547 directed William Paulet, Lord Russell, the Earl of Warwick and Mildmay to compile an inventory of household goods left by King Henry VIII. Mildmay and Paulet served on most of the commissions, the purpose of which was to investigate rather than reform. See S. E. Lehmberg, Sir Walter Mildmay and Tudor Government (Austin: University of Texas Press, 1964), p. 18 .

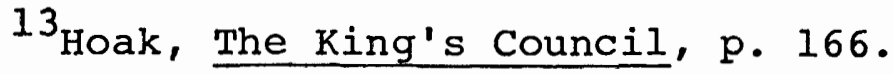


by his own military experience and Paget's insistence that the scottish war was to blame for Edward's desperate financial straits, the war was ended early in 1550. A bankrupt government has little defence against foreign aggression or domestic rebellion, and Northumberland recognized that the Council's first responsibility was the security of the realm. While measures were investigated which would enable the King to "live of his own," the reins of government were tightened to control the populace. The definition of treason was narrowed, the treason laws enforced, censorship exercised and a domestic militia formed in December 1550. These public measures were instituted through the Council and Parliament. The reformed Council procedure, Northumberland's personal control of Council membership, and his use of a small inner group of Councillors for the actual administration of government made such action possible. As will be demonstrated below, Northumberland's financial reforms reflect the functioning of this inner circle, and of cecil in particular.

Circumstances as well as personalities dictated the effectiveness of the Privy Council and the development of the Secretaryship under Edward. The Protector ruled unilaterally, employing both his Council and his household servants for the formalities of governance. Northumberland restored the Council's capacity and allowed its members to make positive contributions to policy. Sir Thomas Smith 
lacked Cecil's gift of leadership and inspired neither trust nor easy friendship. These personal failings certainly Iimited his effectiveness as Secretary. However, Paget experienced the same frustrations under somerset, despite his political and personal attributes. Even Cecil was unable to use his confidential position within somerset's household to wield any real influence on the Protector's policy. Thus the Secretaryship under Somerset was limited by the Protector's autocracy and could be expanded only under Northumberland. It was Cecil's good fortune to be the right man at the right time.

In summary, the Edwardian Privy Council reflects the transitional nature of the mid-Tudor era. Its weakness lay in a susceptibility to human frailty, a carry over of the medieval government's dependence on strong leadership. But Cromweli's reforms had given the board a measure of autonomy which marks the beginning of its modern institutional history. Continuity with the past and an embryonic division of labor combined to prescribe the traditional capacity to give advice with a new competence to translate ideas into action. The serious economic problems of the sixteenth century demanded attention. The financial reforms of 1551 and 1552 exemplify the way in which the Edwardian Privy Council met this challenge. 
CHAPTER IV

MID-TUDOR ECONOMIC PROBLEMS

INTRODUCTION

The economic problems of the sixteenth century contributed directly to the period's social unrest, which in turn sparked political protest. Concern over social rebellion propelled the government toward the alleviation of economic stress. The three areas are closely related. Sorting out strictly economic problems risks distortion, since few sixteenth century analysts separated one sphere from another. Yet there are specific areas of economic change which can be identified, if not completely clarified.

Modern economists isolate inflation, agriculture, foreign trade and domestic industry as critical sixteenth century problems. If sixteenth century writers were less able to make these clear distinctions, their literature reflects the same "griefs." The problems were acute, and Commonwealth men like sir Thomas Smith developed the first techniques for their solution.

\section{INFLATION}

Sixteenth century Europe was plagued by inflation. England had relatively stable prices during the fifteenth 
century followed by sharp bursts of inflation in the sixteenth. Using 1538-1541 as a base period to provide an index of 100 for everyday commodity prices, the abrupt changes become clear.

\begin{tabular}{lc} 
Year & Index Number \\
\cline { 2 - 2 } 1542 & 103.4 \\
1543 & 109.5 \\
1544 & 108.8 \\
1545 & 124.6 \\
1546 & 119.2 \\
1547 & 116.4 \\
1548 & 141.5 \\
1549 & 163.0 \\
1550 & 168.8 \\
1551 & 202.3 \\
1552 & 191.8 \\
1553 & 173.6
\end{tabular}

The period of most rapid price increase was the late 1540s. This fact is reflected in a profusion of Commonwealth protest literature between 1548 and 1556, with most of the commentary appearing between 1548 and $1550 .^{2}$ The causes of this inflation puzzled sixteenth century men and continue to be a subject of debate. . The least typical contemporary Tudor explanation later became the most universally accepted. It attributed the price rise to the influx of New World silver. However, since these imports were not large until

${ }^{I_{A}}$. E. Feaveryear, The Pound Sterling (London: Oxford University Press, 1931), p. 64.

${ }^{2}$. B. Outhwaite, Inflation in Tudor and stuart England (London: Macmillan, 1969), p. I1. 
1545, it is now believed that they could not have affected prices until after mid-century. Had there been heavy importing of silver bullion, the price of silver would have fallen, which it did not. The currently accepted long-term explanation rests upon the law of supply and demand. A significant rise in population in the first half of the sixteenth century put pressure on an agrarian economy which had not yet improved its production. Increased government spending on wars, interest on government loans, the expansion of government posts and perquisites, as well as the rising costs of the royal household were additional factors. ${ }^{3}$ This was also a period when land began to be used as a source of wealth beyond its agricultural yield. Those who bought monastic land often did so to realize income as rentiers. As land ceaspd to be the onlysource of wealth, the expansion of credit pushed prices upward. Finally the debasement of the coinage added to inflation.

Debasement of the coinage as a cause of inflation is critical to understanding Sir Thomas Smith's economic thought. 4 In 1546 Cardinal Wolsey debased the traditionally

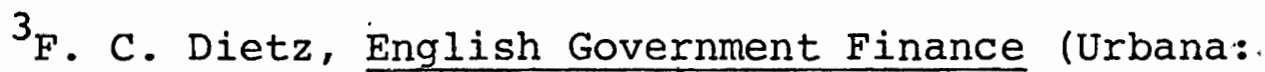
University of Illinois Press, 1921), p. 188. Dietz contrasts Henry VIII's household expenses of $\pm 38,000$ with $£ 56,000$ spent by Edward VI.

${ }^{4}$ Sir Thomas Smith analyzed contemporary economic and social problems in his Discourse of the Commonweal of this Realm of England (1549). His fiscal theory is presented in the Discourse and in his later treatise on the Wages of a Roman Footsoldier, both of which probably influenced william Cecil's economic reforms. See Chapter VII and Appendix II. 
sound English coinage in an effort to stop its outflow to the continent. At the same time he altered the standard from gold to silver. ${ }^{5}$ This practice continued through the 1540s, the period of the Great Debasement. For six years (1544, 1545, 1546, 1548 and 1551) the mints turned out coins with a face value of some $£ 4,300,0000^{6}$ The reduction in their weight and fineness diminished their purchasing power and produced a drop in the exchange between pound sterling against the Flemish pound. This reduction of currency integrity is considered by modern economists to be a significant cause of inflation. ${ }^{7}$

Most contemporary comment, however, focused on sheep, human avarice and the middleman as a manipulator of prices. Commonwealth men were essentially conservative and looked to the past to explain contemporary problems. Debasement was cited as a cause of inflation only by the most astute Tudor commentators, but even they varied in their analyses. The anonymous author of Policies to Reduce this Realme of England unto a Prosperous Wealthe and Estate (1549) tackled the problem of debasement and manipulation of the foreign exchange, clearly recognizing their influence on rising

${ }^{5}$ Geoffrey R. Elton, Reform and Reformation: England 1509-1558 (London: Edward Arnold Pubs. Ltd., 1977, p. 312.

${ }^{6}$ Peter Ramsey, Tudor Economic Problems (London: Victor Gollancz, Ltd., 1966), p. 118 .

${ }^{7}$ Outhwaite, Inflation in Tudor and Stuart England, pp. $23-36$. 
prices. Looking backward, the author advocates a return to the price level of 1529 by paying less for bullion at the mint.

- . so that although ther were none other cawses to make thinges deare but only the falling of the exchaunge. . . for nothing hathe brought the exchaunge so lowe but only the highe price that the kinges maiestie gyveth for golde and silluer at his mynttes.

And then may the kinge, if it shall please his maiestie pute to the poune weigt but sixe ounces of Deloye and $\mathrm{vj}$ oz. Siluer. His maiestie may coyne also as base as he nowe Coy-
neth and then shall his gaynes be mouche greater.8

However, this is rudimentary economic thought. As will be shown in more detail below, the author of the Discourse of this Commonweal of England went more directly to the heart of the matter.

- . And now I must come to that thinge . . which I take to be the cheife cause of all this dearth of thinges, and of the manifest imporishment of thie Realme, and might in briefe time be the distruction of the same, yf it be not the rathere remedyede, that is the basinge or rather corruptinge of oure coine and treasure; whearbie we haue devised a waie for the straungers not onlie to bie oure gould and silver for brasse, and not onlie to exhauste this Realme of treasure, but also to bie our chiefe commodities in manor for nothinge. 9

By the beginning of Elizabeth's reign, debasement had

${ }^{8}$ R. H. Tawney and Eileen Power, Tudor Economic Documents, Volume III (London: Longmans, Green \& Co., 1924), p. 318.

${ }^{9}$ Sir Thomas Smith, Discourse of the Commonweal of this Realm of England, Mary Dewar, ed. (Charlottesville: University of Virginia Press, 1969), p. 69). 
become the accepted explanation for inflation. However, in 1549 most written and oral comment merely protested against the practice without understanding its economic implications. ${ }^{10}$ When Bishop Latimer criticized debasement from the pulpit in March 1549, he expressed a common resentment.

We haue nowe a prety litle shilling, in dede a very pretye one. I haue but one, I think, in my pursse, and the laste daye I had put it awaye almoste for an olde grote, and so I truste some wyll take them. The fynes of the siluer I can not se. But therein is prynted a fyne sentence: this is, Timor Domini fons vitae vel sapientiae. The feare of the Lorde is the fountayne of Iyfe or Wysdome. I wolde god this sentence were alwaies printed in the herte of the kynge in chosyunge hys wyfe, and in al hys officers.11

In an effort to "save face" for young King Edward, Somerset issued the first coins of Edward's reign bearing the frontal image of Henry VIII. With use, the copper alloy soon wore through the thin film of silver with which the debased coins were washed at the mint. Henry's red nose was commemorated in John Heywood's couplet:

These Testons look red: how like you the same? Tis a token of grace; they blush for shame.12...

Contemporaries were, then, well aware of rising domestic prices and a decline in the intrinsic value of the

\section{p. 18 . \\ 10 Outhwaite, Inflation in Tudor and Stuart England,}

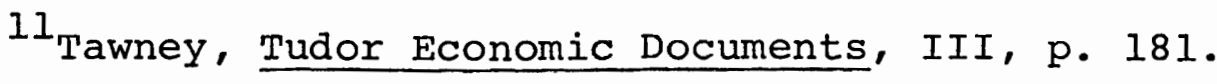

12 W. R. D. Jones, The Tudor Commonwealth 1529-1559 (London: The Athlone Press, 1970), p. 140 . 
coinage. ${ }^{13}$ They saw that there was a discrepancy between the price of silver on the London exchange and at Antwerp. However, few were aware of the causal relationship between these factors. ${ }^{14}$ In January 1551, after visiting the mint at York, William Lane, a London merchant, wrote to William Cecil and revealed alarm at the threat to the exchange which he attributed to the newly debased coins.

Now, for as myche as yt ys well known that the exchange betwene owre Reme and other forin Remes ys the very Rule that settythe the pryse good chepe or dere of all most all thy(n)ges where of ys no skarsyte, as well off the comodytys and mercha( $n)$ dyes of this Reme as of other forin comodytys browght hyther, I wyll declare whate presente myscheffe hathe haypynd sense my commymycasyonn with Yorke. . . The exchange as well for flanders, france as spayne amonge the mercha $(n)$ tes ys fally abowte vij in $C$ by Resonn of the newys of the new qyune commy $(n)$ ge furthe . . . So that shortely we schall be quite off all owre Ryche mony for a base quyne; and than schall folowe a gretar fall of the exchange, wyche ys the father of all darthe of almoste all thynges that man occapyythe. 15

${ }^{13}$ C. E. Challis, "The Debasement of the Coinage 15421551," Ec.H.R.', 2nd Series, 20 (1967), p. 455. "The intrinsic value of $a$ lb. (weight) of coin is the value of fine metal it contains and can be calculated by multiplying the number of $\mathrm{oz}$. Of fine metal in $a \mathrm{lb}$. by the price of fine metal/oz. The difference between this intrinsic value/lb. and the face value/lb., or the value at which the coin was to circulate in the economy, is the king's gross profit/lb. Therefore, if the intrinsic value is calculated and added to the king's gross profit/lb., this represents the value/lb."

${ }^{14}$ Sixteenth century men can hardly be blamed for not understanding the various factors which determine currency values. For further discussion of this complicated subject, see: W. R. D. Jones, The Tudor Commonwealth, p. 141; Outhwaite, Inflation in Tudor and Stuart England, p. 22; Elton, Reform and Reformation, p. 323: Peter Ramsey, The Price Revolution in Sixteenth Century England (London: Methuen \& Co., Itd., 1971), p. 5 . 
These extracts show that protesters linked debasement with inflation, or "dearth." They also reveal a limited capacity for methodical analysis or understanding of fiscal relationships. Against this general level, Sir Thomas Smith's Discourse stands out sharply, making it "beyond question the century's outstanding contribution to social and economic analysis." 16

\section{AGRICULTURE}

Land rules everything in a country where nine-tenths of the people earn their living from the land. This was the case in sixteenth century England. There was a new trend toward exploiting land as a business asset, but rising prices continued to have a profound effect on all persons connected with the land, or almost the entire population. As prices rose, efforts were made to increase the land's financial yield. Although there were husbandry books, scientific farming was in a rudimentary stage and did little to enhance productivity. An alternate "crop" came to replace corn, as farmers discovered that raising sheep required less labor than farming, thereby reducing production costs. Efficiency came through the consolidation of small farms, or engrossing, and acreage that was unsuitable for farming was utilized as sheep pasturage. This concentration on stock, some cattle but mostly sheep, altered society. 
Small tenant farmers were evicted when landlords enlarged their holdings and required only a few shepherds to mind their flocks. Villages accustomed to using common land lost this means of supplemental income as open fields were engrossed or enclosed. The modest men of society, farmers and artisans who also farmed small plots, left the towns and joined the vagrants. With less land being farmed, prices of agricultural products rose, aggravating the cycle and pushing more landowners to pasturage.

The degree to which the enclosure movement contributed to this inflationary spiral was debated in the sixteenth century just as it is now. In 1955 Elton wrote that pasturefarming, despite measures to arrest it, continued "to peak in the years 1540-1555."17 Then, in 1977, he stated:

The twenty buoyant years after about 1505 saw the managers of monastic property join in the general enterprise (enclosure and sheep farming); thereafter they shared in the relative retreat from development. 18

Ramsey offers statistics to show that,

- . the picture is one of two active periods of enclosing at the very beginning and the end of the Tudor period, with a comparative lull in the middle decades. This is the reverse of what we might expect from the intensive propaganda of the mid-century, but quite consistent with the more strictly economic evidence. 19

${ }^{17}$ Elton, England Under the Tudors, p. 231.

${ }^{18}$ Elton, Reform and Reformation, p. 244 .

${ }^{19}$ Ramsey, Tudor Economic Problems, p. 27. 
Ramsey's conclusions are those currently accepted by economists. An example of Tudor complaint literature illustrates Ramsey's "intensive propaganda."

Certain Causes Gathered Together Wherein

Is Showed The Decay of England

Only by the great multitude of sheep, to the utter decay of household keeping, maintenance of men, dearth of corn, and other notable discommodities approved by six old proverbs.

As touching the first proverb of the six, we do think

The more sheep, the dearer is the wool.

The more sheep, the dearer is the mutton.

The more sheep, the dearer is the beef.

The more sheep, the dearer is the corn.

The more sheep, the scantier is the white meat.

The more sheep, the fewer eggs for a penny.

$(1550-1553)^{20}$

For purposes of this study, the importance of enclosures lies in the degree to which men thought they were a cause of inflation. The movement was sufficiently widespread to provide a tangible target toward which protestors could direct the blame for inflation and social dislocation.

Anti-enclosure sentiment was high in the late 1540s. As part of his campaign for popular support in 1548, Protector Somerset permitted the appointment of a commission to investigate enclosures in the midland counties. This was the suggestion of John Hales, "that notable example of the

20 William H. Dunham and Stanley Pargellis, eds., Complaint and Reform in England, 1436-1714 (New York: Oxford University Press, 1938), pp. 135-36. 
confident economic expert who gets it all wrong." 21 Peasants and small landholders interpreted this as Somerset's support for their contention that enclosures by greedy landlords caused both shortages and high prices. The hopes of the farmers thus raised by the commission were soon frustrated by lack of corrective steps, feeding a rising tension which erupted in Ket's Norfolk rebellion in July 1549. This rebellion contributed directly to Somerset's fall in October. It follows, then, that while the measure of enclosure damage was exaggerated at mid-century, the practice had a profound effect on social, economic and political developments.

\section{FOREIGN TRADE}

Overseas trade further complicated the economic picture. The movement to sheep raising was stimulated by overseas demand for English wool. From the time when the Romans crossed their fine-haired sheep with the native Cotswold flocks to produce a long, heavy staple, English wool had been superior to all other and the basis of a thriving wool trade between England and the Continent. Since English finishers were less skilled than Flemish, English merchants found their best market was for unfinished cloth. Although woolen cloth dominated England's export trade in the sixteenth century, raw wool continued to be 
shipped to Calais, where its resale was controlled by the Merchants of the Staple. Thus England's foreign trade was dependent on a single industry, which caused some contemporary alarm. In return for woolen cloth, most imports were luxury goods--wine, pepper, hats, gloves, ribbons, pins and beads. In an age which theoretically scorned ostentation, there was popular complaint that English treasure was being exchanged for high-priced trifles.

From 1486 on, much of the cloth trade was conducted by the Merchant Adventurers, a group of merchants who traded individually according to established rules. Together they shipped their cloth to Antwerp, the exchange depot for both cloth and currency. A traditionally advantageous exchange rate and the brisk activity of the Adventurers resulted ultimately in a saturation of the Antwerp cloth market in 1550 and a financial crisis followed in 1551. Contributing to this crisis was the fall in the exchange rate between London and Antwerp, brought about by the successive coinage debasements of the 1540s. In 1526, one English pound had brought 26s. 8d. Flemish. By July 1551, the pound had dropped to 13s. 4d. in Flemish currency, a distressing development for the merchants in Antwerp and Calais who then had difficulty raising loans.

Throughout the period, attempts were made to control the quality of woolen cloth, regulate its export, set minimum prices and thus monitor the effect of foreign trade on 
currency rates. These measures had little effect, however, for the government lacked both the money and the personnel to enforce regulatory policies.

\section{INDUSTRY AND TOWNS}

Regulation of domestic industry was as difficult as control of foreign trade. Proclamations setting prices for specific commodities were issued in fits and starts in response to public outcry against inflation, but again enforcement was lax. Proclamations could be issued, but relying on reluctant local officials to enforce unpopular policies and "turn in" their friends proved to be another matter. Even legislation passed by Parliament had little positive effect. Reflecting upon the year 1548 when he supervised Somerset's economic policy, John Hales wrote about his failure.

- . as there be many good men that take great pains to study to devise good laws for the commonwealth; so there be a great many that do with as great pains and study, labor to defeat them; and as the common saying is, to find gaps and starting holes. 22

Control of commodity prices aroused indignation, particularly from the "middlemen." On December 4, 1550, Sir John Mason wrote from France to Secretary Cecil:

I hear here a great bruit of the discontention of our people upon a late proclamation touching cheese and butter; of a little thing we make here a great

22 Jones, The Tudor Commonwealth, p. 205. 
matter. And surely, if there be no other thing than I do see in the thing, the matter might even as well have been spared. I have seen so many experiences of such ordinances; and every the end is dearth, and lack of the thing that we seek to make good cheap. Nature will have her course, etiam si furce expellatur; and never shall you drive her to consent that a penny-worth of new shall be sold for a farthing. If good cheap follow this device, then hereafter will I think it were good the like were still used; but this I am sure, the thing shall not be so plentiful as it was, and then I report me to you whether it will be better cheap. For who will keep a cow that may not sell the milk for so much as the merchant and he can agree upon? 23

At mid-century there is evidence of increased governmental intervention in economic matters. While the maintenance of public order remained the primary motive behind this activity, there was a growing paternalism in Commonwealth thought which assumed government obligation for the welfare of the realm. What made the task so difficult was that the problems were far more sophisticated than the government's means of dealing with them. Control of industry and trade by public edict was in its infancy.

The production and manufacture of wool was the most . important domestic industry during the Tudor period. The western counties of Somerset, Gloucestershire and Wiltshire had a ready supply of Cotswold wool. The industry in East Anglia concentrated on cloth, dyed and finished, and boasted a skilled labor force. Rough, cheap cloth was produced in Yorkshire where less arable land supported sheep, and an

${ }^{23}$ P. F. Tythler, England Under the Reigns of Edward the Sixth and Mary, I, (London: Richard Bentley, 1839), p. 341 . 
ample supply of running water fostered the growth of a finishing trade for clothiers. The industry consisted of home workshops where artisans worked on a piece basis for clothiers who supplied them with raw materials. As a result, the saturation of the export market in 1550 created a domino reaction which was felt from the merchants in Flanders down to the most humble crofter. Vulnerability from top to bottom was a consequence of England's dependence upon a single export staple.

The domestic system which characterized the woolen industry ran counter to the gild system, the medieval means of creating trade monopolies and regulating production. The gild system was in decline during the Tudor period, although town government was usually dominated by wealthy merchants who were also prominent gild members. It was their responsibility to maintain public order and discourage vagrancy. However, providing these services was a financial burden for declining towns. Freer market conditions, increasing industrial specialization and the attraction of the domestic system caused a downswing in the fortunes of many towns, a problem made worse by inflation. Thus the decay of towns became one of the grievances attributed to mid-century "dearth." 


\section{CONCLUSION}

The social ramifications of these economic problems were great because all groups who lived on fixed incomes suffered from increasing prices. The source of income, as indicated, was in almost all cases land. The old nobility based its wealth on land which provided income from rent and from farming. Long term leases meant proportionately lower returns on the land as inflation increased. Later in the century this group turned to innovative methods to enhance the return on their estates, but at mid-century many were hard put to meet the costs of maintaining their station in life with a diminishing resource. Had the so-called "new nobility" depended on their estates alone, they too would have suffered. They survived because many had received Church land and prospered from the benefits of royal service. Social mobility allowed for a "rising gentry" as exemplified by William Cecil, William Paget and William Paulet. Much has been written about the movement within this group, but whether Court or Country, gentryman or peer, the man who could not supplement an income derived from land suffered from inflation in the same manner as the peasant. Those who escaped this trap were the merchants who, in theory, could pass on their increased costs. Later, this group financed industrial expansion under Queen Elizabeth. The merchants' relative prosperity at mid-century made them easy targets for pamphleteers complaining about economic 
hardship. The widespread impact of inflation led to class tension, as each blamed the other for its troubles. With time, the new fluidity between classes brought on a breakdown in the social hierarchy. This can now be seen as a step toward the modern era, but for Tudor men it was the cause of discontent and insecurity. An essentially conservative populace turned to the past to explain its "griefs" but this was tempered by a new concern for public welfare in a paternalistic society. Recognition of these social and economic changes was a significant contribution of Commonwealth literature at mid-century. 
CHAPTER V

MID-TUDOR COMMONWEALTH THOUGHT

INTRODUCTION

The Commonwealth literature of the mid-Tudor period was a further development of the movement toward reform initiated by Erasmus and Sir Thomas More. While Erasmian reform focused upon a return to doctrinal purity, later reformers moved away from the religious context. The concept of Commonwealth became all-encompassing.

In the fifteenth century, sir John Fortescue wrote of a body politic with head and members analogous to the human form. The head of this body assumed the medieval position of God's agent on earth. As such he was responsible to God for his actions, the direction of which was to be toward the welfare of the realm. When first used in the fifteenth century, "commonwealth" meant body politic. Two centuries later, Oliver Cromwell's Commonwealth signified an entity far different from the body politic, for it had no head. This was the English experiment in government by parliament alone, without a King. Between these two periods, developments in the sixteenth century shaped men's thought toward a Commonwealth which implied an ideal state in which communal interests took precedence over those of the individual and 
in which it was the government's duty to promote the general welfare. The concept is a fine example of the transitional nature of mid-sixteenth century thought. This Commonwealth was an extension of medieval "good lordship," a relationship contingent upon a responsible king and obedient subjects. Intellectual historians base their emphasis on continuity in mid-Tudor thought on this paternalism. However, an increase in man's role in the achievement of this conservative ideal emancipated the sixteenth century Commonwealth from medievalism. Recognition that the changes in society were manmade, and were part of an overall pattern of change, is a Renaissance characteristic attributable to the influence of humanism. Intellectual historians correctly emphasize conservatism and continuity in the ideal commonwealth, but this must not overshadow a significant break with medieval tradition. Sir Thomas More's Utopia was 'nowhere,' a purely theoretical state. At mid-century, Sir Thomas Smith's Discourse of the Commonweal of this Realm of England treated the real world. In it the author proposed practical solutions to man-made problems. The new emphasis on this world was part of the evolution in the meaning of the word commonwealth.

Sixteenth century thought centered on the attempt to bridge the gap between the real and the ideal. From Erasmus to Sir Thomas Smith, man sought harmony. Religion and politics overlapped in teaching that through obedience, social 
and moral stability would be maintained. A Great Chain of Being in which all creatures had a place in the hierarchy provided a sense of security. Obedience to a superior power, be it God or King, moral or legal code, was the accepted means to a unity of order and degree. Fundamental to this pattern of thought was the belief that the king, ordained by God, must secure the welfare of the realm. This medieval tenet was tempered by the humanist belief that the King could be guided to good rule through proper education. This instruction was the purpose of the various 'Prince books' of the late fifteenth and early sixteenth centuries. The concept of unity, in religion and in politics, implied order, safety and security. Sixteenth century reformers sought to obtain this state of harmony.

The reform literature written before 1540 concentrated upon religion. This tradition continued with the writing of the more radical clergy such as cranmer and Latimer. They were supported by the Cambridge scholars brought to Court as tutors to the royal children. They often met with a third group of literate Commonwealth men which consisted of laymen-statesmen. The outstanding members of this circle were John Hales, Thomas Smith and William Cecil. The greatest evidence of special concern for the broader aspects of the Commonwealth concept can be found in the writing of this group. The work of Hales and Smith, while assuming obedience 
within a paternalistic state, was wholly secular in its approach. ${ }^{1}$

A DISCOURSE OF THE COMMONWEAL OF THIS REALM OF ENGLAND

The superior analysis and methodology of the Discourse precludes citing it as a typical example of Commonwealth literature. Rather it is offered as the best piece of humanist thought at mid-century. It is the work of a true Renaissance man, a scholar and statesman, the product of a humanistic education utilized in service to the state. As was much of this protest literature, the Discourse was written anonymously and was not published until after Smith's death in 1581. However, Thomas Smith's authorship has been established and July/August 1549 determined as the period when smith undertook the task. ${ }^{2}$ This date places it amid a plethora of Commonwealth literature. In all other respects the Discourse stands apart from contemporary writing on complaint and reform. Not only is Smith's methodology superior, it anticipates the analytical approach

${ }^{1}$ John Hales, Keeper of the Hanaper in Chancery, wrote a treatise in 1549 entitled In Defence of John Hales. Careful analysis of his thesis shows it to be inferior to the Discourse. He was single-minded in his abhorrence of enclosures.

2 Mary Dewar, "The Authorship of the Discourse of the Commonweal," EC.H.R., 2nd series, 19 (1966), pp. 388-400. With the exception of $W$. K. Jordan, contemporary historians accept smith's authorship. 
characteristic of Cecil's financial reforms of 1552. Since it was common practice to circulate these anonymous tracts among friends, it is probable that Cecil read Smith's Discourse and certainly its proposals would have been the subject of conversation between confidants. Thus the similarity between Smith's thought and Cecil's reforms becomes more than coincidence.

\section{Methodology}

Smith structured the Discourse carefully. His methodology shows that he not only gave consideration to the content of his proposals, but also to the manner of their presentation. Though probably written to relieve the frustration of his "exile" in Eton, the comprehensive scope of his thought and the depth of his analysis reveal that the Discourse resulted from investigation and contemplation over a period of some months after Smith had completed his financial survey for somerset in the spring of 1549. The conviction and eloquence with which Smith's Doctor speaks come from mature thought.

Smith divided his work into three main sections, a reflection of his own classical study. He stated the problems, studied their causes and offered remedies. In so doing, he approximated a scholastic "thesis, antithesis and synthesis" format which well suits his dialogue. Within his categories, Smith organized his material to reveal class interests and animosities. The elements of society most 
specifically affected by social and economic problems were represented by characters who spoke in a dramatic dialogue, the convention of the period. Smith differentiated between fundamental and contributing problems by isolating the "efficient" cause from secondary factors. Anticipating a systematic economic policy, his remedies were to be carried out in order of importance to ensure a relief predictable in extent as well as in the length of time necessary for accomplishment.

Another aspect of Smith's methodology appears in a later section of the Discourse where the author explained that analysis can be based upon either precedent or "art." Precedent depended upon the medieval technique of looking back to the Commonwealth "when it was well." This had been, and was to continue to be, man's conventional way of remedying inexplicable changes in his environment or to rationalize reforms. Generations of English kings had justified their policies as restoration of good law "from the time of my grandfather." What was customary was comfortable, and therefore precedent was relied upon by conventional reformers and pamphleteers. By "art," Smith meant the systematic dissection of problems, their causes and remedy. This appears to us as something less than revolutionary, but Smith was one of very few men capable of comprehending the complex nature of England's social and economic problems, isolating the components, and articulating their order of 
priority. This distinction enhances the stature of the Discourse.

\section{Content}

Smith was not a diffident man. With characteristic confidence, he began his work with "A Table of Things Most Notable Contained in This Book." Here he listed the "maxims" which the text elaborated. Lest we miss the point, he carefully restated these in footnotes. In this way, Smith provided his reader with a summary of the book's contents.

The three dialogues were prefaced by an introductory section, or prohemium, in which Smith stated his reason for writing the Discourse. Its content was to be "the manifold complaints of men touching the decay of this Commonweal." 3 Through "some discourse with myself," Smith's plan was: "First, what things are most grieved with, then what should be the occasion of the same, and that known, how much griefs may be taken away and the state of the Commonweal reformed again." 4 smith assessed contemporary problems realistically, in a manner free from moral judgment, and showed how they affected specific segments of society. In analyzing the causes of the "complaints," he again thought independently,

${ }^{3}$ Sir Thomas Smith, A Discourse of the Commonweal of this Realm of England, ed. Mary Dewar (Charlottesville: The University of Virginia Press, 1969), p. 11. (Hereinafter footnoted as "Smith, Discourse.")

${ }^{4}$ Smith, Discourse. 
casting aside the conventional anti-enclosure sentiment and citing debasement of coinage as the major cause of inflation. This point marks Smith as an original thinker. Although the causes of early sixteenth century inflation remain a subject of debate, the most recent opinion substantiates Smith's conviction. 5 The practicality of smith's solutions places him apart from his contemporaries, most of whom stopped short of offering solutions to problems. They were content merely to list their complaints. His plan for long-term correction, despite short-term hardship, was designed to benefit the entire realm, to enhance the common weal. It demonstrates the dimension of his mind. Smith's proposals presaged both mercantilism and utilitarianism and again distinguish Sir Thomas Smith as a man ahead of his time.

The Preface reflects the Commonwealth assumption that treating the ills of the realm was the government's responsibility. Smith stated here that the King's Council must consider reform of the Commonwealth, a task shared by "the Common House where such things ought to be treated of." 6 This somewhat ambiguous assignment of function shows that the lines of demarcation between Conciliar and Parliamentary responsibility were not yet distinct. Smith went on to say

${ }^{5}$ J. D. Gould, The Great Debasement (Oxford: Clarendon Press, 1970), p. 1; Outhwaite, Inflation in Tudor and Stuart England, p. 22; Ramsey, Tudor EConomic Problems, p. 118 and The Price Revolution in Sixteenth Century England (London: Methuen and Co., Itd., 1971), p. 5.

${ }^{6}$ Smith, Discourse, p. 11 . 
that these matters could be spoken of not only by Members of the Common House but by any member of the Commonweal. Though he was not the master of the ship (of state), the danger of a wreck still threatened him. This common analogy was used by Smith to illustrate the maxim stated at the bottom of this folio: "no man is a stranger in the commonweal that he is in." 7 In like terms, he indicated that many heads are better than one and urged princes to seek counsel from scholars, merchants, husbandmen, artificers and gentrymen, since the "gift of wit be so divers." 8 Here Smith is the humanist scholar suggesting the value of diverse opinion and suggesting that each advisor be "credited to his own art." After the usual apology for "my poor conceit," Smith stepped forward as the learned Doctor of "Philosophy Moral," a field which for him encompassed "policy or good government of the Commonweal." A basic tent of English humanism was the belief that through a thorough study of the classics essential morals will emerge which can be translated into reform of the realm.

Before launching into the main body of his treatise, Smith added a final word of cautious explanation for his project. No doubt because of the precarious state of his own career during the summer of 1549, Smith spoke from the

$$
\begin{aligned}
& { }^{7} \text { Smith, Discourse. } \\
& { }^{8} \text { Smith, Discourse, p. } 12 .
\end{aligned}
$$


heart and probably to his friend Cecil when he stated: "And since this is between us two and to be weighed only and considered and not to be published abroad." 9 only in this way could he risk proposing "things that were not openly to be touched." He hesitated to offend somerset (further) and yet felt compelled to proceed with his analysis, for "hard were it to heal a sore that a man would not have opened to his physician." 10

Smith treated the full spectrum of problems by identifying five "griefs" from which his contemporaries suffered. These were: universal dearth, exhausting of the treasure of the realm, enclosures, decay of towns and the diversity of religious opinion. His five principal characters are the Merchant, the Knight, the Husbandman, the Capper and the learned Doctor (Smith). Through them Smith associated particular grievances with particular social classes. The five principal complaints are set in a broader context of Commonwealth concerns. This procedure enabled smith to present his views on the role of government in determining the welfare of the state, on education, and on economic and religious reform. These subjects make up what may be termed the explicit content of the Discourse.

Implicit in the Discourse are Smith's methodology, the

${ }^{9}$ Smith, Discourse, p. 8.

${ }^{10}$ Smith, Discourse, p. 13. 
humanist philosophy of education, and a sophisticated monetary theory. Smith's monetary theory must be pieced together from various sections of the Discourse but it can be discerned in a surprisingly complete and modern set of ideas. This theoretical aspect of the Discourse further distinguishes it from contemporary pieces. Smith's monetary theory bears on our later discussion of financial reform and serves as a useful example of Smith's sophisticated thought. Economic problems such as inflation can be explained either by a monetary theory or one which considers 'real' factors such as population change, crop failure, or even that popular villain 'avarice.' A monetary approach studies fluctuations in currency and prices. In singling out debasement as the central cause of inflation, Smith revealed his awareness of the interrelated, circular nature of economic activity with particular reference to domestic currency and its exchange rate. ${ }^{11}$ The majority of pamphleteers blamed human greed for the conversion of tillage land to pasturage which in turn brought high prices. Smith's monetary approach is unique in Commonwealth literature for i.ts comprehension of fiscal problems. The following excerpt from the Discourse contains Smith's theory of prices and provides an example of the quality of his analysis.

\footnotetext{
${ }^{11}$ Outhwaite, Inflation in Tudor and Stuart England, p. 21 .
} 
We must consider, though gold and silver be metals commonly wherein the coin is struck to be the tokens for exchange of things between man and man, yet (it) is the wares that are necessary for man's use that are exchanged, indeed under the outward name of the coin, and it is the rarity or plenty of such wares that makes the price therof base or higher.

And because that it were very cumbersome and chargeable to carry so much of the wares that we have abundance of to exchange. . . . therefore were the metals of gold and silver devised as wares of so little weight, most in value, and least cumbersome to carry, and least subject to detriment or hurt in the carriage thereof, and may be cut and divided in most pieces and portions without any loss, as the mean wares to exchange all other wares by. 12

Smith distinguished between the intrinsic view of money and its utility as token. He also realized that monetary values work in conjunction with the law of supply and demand. In addition to his pricing theory, smith stated what has come down in history as "Gresham's Law," recognized the power of self-interest as an economic force, and saw the importance of industry in the economy and the attendant role of a domestic labor supply. ${ }^{13}$ His constant teaching that treasure must be kept within the realm through advantageous terms of foreign trade has earned his treatise the tag "mercantilist pamphlet."14 The Discourse is Smith's mechanistic statement

12 Smith, Discourse, p. 71.

${ }^{13}$ See Discourse p. 54 for self-interest, p. 122 for domestic employment, pp. 34 and 101 for Gresham's Law, p. 98 for clock analogy.

${ }^{14}$ Arthur B. Ferguson, The Articulate Citizen and the English Renaissance (Durham: Duke University Press, 1965), p. 104 . 
of economic laws. In fact, Smith abandoned the corporate analogy of body politic and used the clock to show the force of one factor against another. Because one gear moved the next, it was essential to isolate the "mainspring," or "essential" cause, of inflation. Correction of this problem would generate further economic reform.

The weakness of a purely monetary theory for explaining inflation is that prices do not always increase in proportion to the reduction of silver content in silver coin, nor in proportion to the increase in the face value of the coinage in circulation. ${ }^{15}$ As a result, modern economists use a combination of monetary and "real" analysis, but the latter remained the accepted practice well into the nineteenth century. Thus Smith was indeed exceptional in developing a monetary theory independent of the traditional explanation of inflation based upon purely physical factors. As suggested above, Smith discussed specific complaints, their causes and remedies in the three dialogues of the Discourse. The five problem areas were separate, but Smith stressed that the solution to all lay in his suggested remedy for the fundamental cause of inflation, the alteration of the coin.

${ }^{15}$ Ramsey, The Price Revolution in Sixteenth Century England, p. 8 . 
Universal Dearth or Inflation. The first "grief" analyzed in the Discourse is the "universal dearth."16 Men of all ages have been able to connect bad harvests with high prices. What troubled men who suffered from the accelerated inflation of the $1540 \mathrm{~s}$ was the conundrum posed by the Knight: "the dearth of all things though there be scarcity of nothing." 17 The Merchant was aware that both domestic goods and imports had increased in price, that the increase had been about $33 \%$ in a seven year period, that the basic food stuffs were in good supply and had been for three years. Since God had sent good harvests, high prices could not be attributed to Divine Will.

Merchantman: for there is such a general dearth of all things as I never knew the like, not only of things growing within this realm, but also of all other merchandise that we buy from beyond the sea . - . I wot well that all these do cost me more by the third part well than they did but seven years ago. Then all kinds of victuals are as dear or dearer again, and no cause of God's part thereof, as far as I can perceive, for I never saw more plenty of corn, gra'ss, and cattle of all sort than we have at this present and have had, as you know, all these past three years continually. . . .18

Smith stated the basic conflict of high prices in the midst of plenty. He spoke of a $50 \%$ rise over a twenty-year period and a $33 \%$ rise during a seven-year period, indicating

${ }^{16}$ In the sixteenth century "dearth" meant dearness, not scarcity as it does today.

${ }^{17}$ Smith, Discourse, p. 37.

${ }^{18}$ Smith, Discourse, p. 18 . 
the increased pace of inflation in the 1540s. Smith's figures are supported by modern calculations. 19 In a country where the overwhelming majority of men lived on the land, men first turned their thoughts to supply as they attempted to explain price changes. Crops had been plentiful and "victuals" therefore abundant. Bad harvests had long been explained as acts of God, but since recent harvests had been good, Smith dismissed this possibility and said that the dearth was man's doing. Here man blamed man. This sentiment fed a growing class tension which Smith demonstrated throughout the Discourse as each character cited complaints and their causes.

The Doctor is the one character able to look dispassionately at the problem of inflation and his comments provide the broad context for Smith's discussion of other specific points.

The Doctor suggested that before examining the causes of the dearth, the group should consider "what state of men be grieved indeed by this dearth of things." 20 pointing out that those who sell goods, both artificers and merchants, could pass on their high costs through higher prices, men "such as have their livings and stipends rated at a

${ }^{19}$ See Feaveryear table above, p. 54. ${ }^{20}$ Smith, Discourse, p. 34 . 
certainty, such as common laborers at $8 \mathrm{~d}$ a day, the journeymen of all occupations . . and gentlemen whose lands are let out by them of their ancestors" are most severely "pinched." 21 Smith appreciated the King's predicament. As the greatest landholder, the king lost most by the universal dearth. His land revenues could not keep pace with inflation and thus he was forced to seek other means of meeting expenses. (Certainly this was the crux of King Edward's problems in 1549.) At all costs, the King was to avoid the disastrous practice of coin debasement and strive to restore the treasure of the realm. This mercantile concept constitutes the second major complaint discussed in the Discourse. Exhaustion of the Realm's Treasure. The exhaustion of resources endangered the realm and therefore related to the problem of security. The king needed a ready source of money to meet the emergency of war and the attendant costs of soldiers, food, ammunition and transportation. The realm had to be ready for the bad harvest expected every seven years. Growing a surplus would provide the necessary reserve. Such action would avert the necessity of having "to seek it from outward parts and pay dear for it," further depleting the treasure. ${ }^{22}$. It should be noted that this line of thinking emerged in King Edward's Journal entries for 1552, the

$$
\begin{aligned}
& { }^{21} \text { Smith, Discourse, p. } 35 . \\
& { }^{22} \text { Smith, Discourse, p. } 60 .
\end{aligned}
$$


substance of which probably came from cecil. 23

Enclosures. The desolation of the counties by enclosures is Smith's third major topic. As indicated above, the evils of enclosure constituted the dominant theme of popular protest literature. Sheep, sheep, sheep echoed from every corner. Accordingly, Smith's Husbandman says: "Yes, those sheep are the cause of all these mischiefs; for they have driven husbandry out of the country . . "24 The Knight sympathized with this position but explained that men of his class had to raise some sheep in compensation for the fixed return of income from old copyholds. By raising sheep, they had something to sell from which they could realize a profit.

Although enclosure and engrossing had changed the agricultural pattern of sixteenth century England, we have seen that the pattern tapered off after 1520. Smith was aware of this and avoided the anachronism of blaming inflation on enclosures, but somerset fell prey to his practice in 1549. His investigation of enclosures made sense as an appeal to public opinion because small tenant farmers still blamed enclosures for their problems. They believed his Enclosure Commission had been designed to stop the conversion of arable lands to pasture. Unfortunately for somerset,

23 Literary Remains of Edward the Sixth, ed. John Nichols (New York: Burt Franklin, 1857), II, p. 545.

${ }^{24}$ Smith, Discourse, p. 22. 
his plan backfired.

The Decay of Towns. In his next topic, the decay of towns, Smith again displayed an accurate understanding of the contemporary scene. His Merchantman noted that, with the exception of London, the "good towns are sore decayed in their houses, walls, streets . . . highways and bridges." 25 He and the Capper observed that the cities were deserted because few craftsmen could afford to pay the higher wages which accompanied the commodity price rise. As employment dropped, merchants suffered. Since they contributed to the upkeep of bridges and highways and maintained some public buildings, these were neglected as merchant income declined. This was the pattern in the countryside. London, Smith knew, was experiencing rapid expansion as the center of government and commercial activity.

Diversity of Religious Opinion. Smith himself was often accused of being "neutral" in matters of religion, but he was very much the man of his time in believing that diversity of opinion led to the breakup of society. His discussion of the problem of religious controversy was presented within the context of national stability and security. This is part of the reactionary pattern of sixteenth century thought as it strove for universal harmony.

${ }^{25}$ Smith, Discourse, p. 18 . 
The Knight spoke for most men:

How this diversity of opinions may be taken away which troubles the people very sore and makes great sedition and division among them and in manner makes debate between neighbor and neighbor, father and son, man and his wife, which is more to be feared yet than all other the foresaid losses of worldly goods. 26

Religious, political, social and economic insecurity influenced mid-sixteenth century reactions and explains the emphasis upon order and obedience. The Discourse confines its treatment of religion to this level and does not touch upon doctrinal matters.

\section{Dialogues Two and Three. Dialogue Two is devoted to} the causes of the principal problems confronting the Commonwealth. Here Smith made his pronouncement that the alteration of the coin was the chief cause of inflation. Dialogue Three contains suggested remedies for the five "complaints." Smith's views on governance and education become clear in this section. As the humanist scholar, Smith's Doctor had more concern for public issues than had an uneducated man. Yet, as previously indicated, he saw the value of a pool of expertise formed from the counsel of various segments of society. It was the citizen's duty to offer such counsel to the King or to his Council. Smith believed, as a Commonwealth man, that the King's policy determined the public welfare. Advice offered through the Council or through Parliament contributed to the formulation of that policy. 
Reliance on the power of man's reason was fundamental to Smith's outlook. Thus the influence of humanism is clear in Smith's own belief that the wise man makes a valuable statesman. He can also render service unofficially by proferring counsel to Privy Councillors and members of Parliament. Although experience had taught the Doctor that such advice was not always welcome, the citizen's duty required that he overcome fear of reprisal. The fundamental Commonwealth principle of a rational and virtuous society achieved through the good governance of responsible and obedient men runs throughout the Discourse. Smith's combination of philosophical and practical analysis can be traced in each of his major topics, but it is particularly evident in: the remedy for debased coinage contained in Dialogue Three.

Smith's own words best serve to convey his subject matter, manner of presentation, depth of understanding and sense of caution in stating his opinions.

Knight: By your tale it must be in the coin and consequently in the King's Highness by whose commandment of the same was altered.

Doctor: Yet, perchance it goes further yet. Yea, to such as were the first counselors of the deed, pretending it should be to his Highness' great and notable commodity, which if His Grace may now perceive to be but a momentary profit and continual loss both to His Highness and also to his whole realm.

Knight: Then you think plainly that this alteration of the coin is the chief and principal cause of this universal dearth?

Doctor: Yea, no doubt, and of many of the said griefs that we have talked of by means it being the 
original of all. And that, beside the reason of the thing, being plain; for even with the alteration of the coin began this dearth, and as the coin appeared so rose the price of things withal. And this to be true, the few pieces of old coin yet remaining testifies; for you shall have for any of the same coin as much of any ware, either inward or outward, as much as ever was wont to be had for the same, and so as the measure is made less there goes more sum to make up the tale. And because this rises not together at all men's hands, therefore some have great loss and some other great gains thereby, and that makes such a general grudge for the thing. And thus to conclude, I think this alteration of the coin to be the first original cause; that strangers do sell their wares dearer to us and that makes all farmers and tenants that rear any commodity again to see the same dearer, and dearth thereof makes the gentlemen to sell their rents and to take farms to their hands for their better provision and consequently to enclose more ground. 27

Smith tactfully avoided blaming Edward or his ministers for the alteration of the coin by pointing out that this action was first taken by Councillors in an earlier reign. To support his contention that diminishing the integrity of the coin was the chief cause of universal dearth, Smith relied on reason and experience, alluded to what we call "Gresham's Law," and recognized the natural force which makes one problem create another.

The section of the Discourse which discusses specific reforms was revised by Smith in 1576.28 For this reason its contents cannot be used to show that these ideas closely

${ }^{27}$ Smith, Discourse, pp. 100-02.

${ }^{28}$ See Appendix I for this section of the Discourse. 
parallel Cecil's reforms of 1552.29 While the specifics of a plan to reform the coinage cannot be documented as belonging to Smith's proposals of 1549, his belief in the relative values of precious metals and in the return to a fine standard of coinage as the cure for inflation resulted from a lifelong interest in numismatics and fiscal manipulations. Smith and Cecil had studied ancient coins together in Cambridge and their continued interest prompted Cecil to ask Smith to write a history of coinage for him. ${ }^{30}$ The wages of a Roman Footsoldier is in essence a disquisition on the history of money in which Smith cites both ancient and modern authors for his theories on the valuation of currency, the evolution of weights and measures, and to suggest parallels between Roman and sixteenth century "decaie of the state" which resulted from arbitrary abatement of the standard of currency. The general economic tenets of the Discourse appear as specifics in the Footsoldier, binding

${ }^{29}$ In her introduction to the Discourse, Mary Dewar describes this altered section "which discussed the impact of the precious metals from the New World on price levels in terms of Bodin's original suggestion." ( $p$. xxvi) What we cannot know, and therefore cannot use as evidence, is whether Smith's plan for recalling the old coins and issuing new ones was part of his early thinking. Certainly they appear to be in line with 1549 content of the Discourse. It can only be noted that this revised section of the Discourse outlines the procedure Cecil followed in 1552.

${ }^{30}$ For evidence that cecil received a copy of this treatise and kept it through the years, see Mary Dewar, sir Thomas Smith (London: The Athlone Press, 1964), p. 188 . 
the two contextually and revealing Smith as a profound economic theorist.

\section{CONCLUSION}

Commonwealth literature in general is of uneven quality and usually reflects only partial understanding of contemporary problems. Its thrust is toward identifying the "griefs" which men suffer and directing blame on human avarice and enclosures. Intellectual historians Jones, McConica and Ferguson have recognized the outstanding qualities of the Discourse which distinguish it from other Commonwealth literature. They have commented upon the influence of humanism on Smith's economic and political considerations. Mary Dewar has authenticated Smith's authorship. To this end she relates statements in the Discourse to those found in Smith's other writing, particularly the Wages of a Roman Footsoldier. All of these historians acknowledge Smith's premier position as a scholar and theorist. Not one, however, suggests that Smith made any impact on the financial policies of mid-Tudor England.

Documentation simply does not exist which will prove that the ideas which Smith presented in the Discourse in 1549 found their way directly into the reforms of 1552. Nor do we know for certain that cecil ever read this anonymous, unpublished work. We can go no further than to suggest a probable set of circumstances. Familiarity with Smith's 
friendships, concern for good government and hopes for improvement in his own political career make it clear that Smith remained close to the center of government through the 1550s. Knowledge of his writing and of the financial reforms effected late in Edward's reign lead to the conclusion that all of these factors combined to make Smith's ideas known to those determining government policy. William Cecil was Thomas Smith's friend. He was also the Duke of Northumberland's man on the Council charged, in 1552, with responsibility for financial reform. 'Smith's conviction that he owed the king "obsequy," the rendering of service, may well have moved him to contact Cecil. Or perhaps Cecil sought the expert advice of his friend when devising his plan to restore the coinage. More probably the two had discussed this matter of mutual concern informally over the years. We can at least speculate that Smith's ideas, through Cecil and Conciliar action, were translated into the coinage reforms of 1552. When a similar set of circumstances arose in 1560, documentation does show that Smith, through Cecil, determined the valuation of Elizabeth's new coins. 31 Through the verbal and written word, the thoughts expressed in the Discourse contributed to the formulation of Commonwealth policy.

${ }^{31}$ C. E. Challis, The Tudor Coinage (Manchester: Manchester University Press, 1978), p. 125. See below, pp.135-37. 
CHAPTER VI

WILLIAM CECIL AND FINANCIAL REFORM UNDER EDWARD VI

\section{INTRODUCTION}

In order to identify a specific link between Smith and Cecil in the reform of fiscal policy, it is necessary to study the financial situation at the accession of Edward VI, analyze the problems of the Somerset era, and outline Cecil's role in the corrective measures of 1550-1553.

\section{SOURCES}

Source material for such a project is limited. Caught in a delicate situation at Edward's death, the always cautious william Cecil probably burned his personal papers. In any event, few remain. It is not surprising, therefore, that the H.M.C.Salisbury Manuscripts contain references to few documents written by cecil auring this reign, although there are summaries of some letters written to him by others. The series of original letters collected by P. F. Tytler contains none by Cecil for this period. The Acts of the Privy Council offer some hints of Cecil's activities and Council policy, but little that is specifically financial. ${ }^{1}$ The this period and in part to an overly selective early editor, 
Calendar of Patent Rolls records some pertinent proclamations, warrants and commissions. The Literary Remains of Edward the Sixth, edited by John Nichols, is a subject of dispute among historians: Jordan and Dietz put store in what they consider are the words and thoughts of Edward, the precocious administrator. Elton and Hoak regard this as a pedant's exercise book, prepared and supervised by cecil. There is no doubt that Cecil, as Secretary the link between King and Council, was closely associated with Edward in administrative matters. He prepared agendas for the King, the Council, and Parliament and many of the entries in this collection were written jointly by Edward and cecil. If not dominated by Cecil, who even at this early stage had learned the art of guiding monarchs, Edward was at least influenced by him. Their close association actually enhances the utility of the Literary Remains as a valid source for a study of financial policy, as it suggests the scope of Cecil's activity.

No doubt because of the scarcity of primary sources,

Ralph Starkey, who wrote in 1620: "There is so much as is contayned in the Bookes of the Actes of the Councell which I abridge (sic) thereout as the most memorable Actes passed." A.P.C. II, vii. The 1891 editor remarked: "The principles which guided starkey in his selection of the extracts are not very clear, but as a rule financial entries are neglected." A.R.C. II, vii. The original documents were apparently lost. 
there are few secondary sources currently available on the subject of Edward's overall financial program. The only comprehensive study of Tudor finance was made by F. C. Dietz in 1918 and it is inadequate for Edward's reign. W. D. Richardson's Tudor Chamber Administration (195.2) pertains only to the revenue courts and can, along with Pollard, be considered out of date in assigning the scheme for reorganizing these courts to the Marquess of Winchester in the next reign. ${ }^{2}$ Modern economists have produced detailed studies

2 The following quotations from Dietz (1918) and Elton (1977) demonstrate the shift in attitude toward finance in the reign of Edward VI:

F. C. Dietz, "Finances of Edward VI and Mary," Smith College Studies in History, 52 , No. 2 (1918), p. 69.

The reign of Henry VII and the early part of Henry VIII's saw the erection of a new revenue system, adequate for a moment to the needs of the government. Between 1542 and 1553 this new system was disintegrated and its adequacy destroyed. This nullification of the work of Henry VII and of Cromwell, as it was completed in the reign of Edward VI, and the first attempt to rehabilitate the remaining resources of the state in Mary's reign are the subjects of this essay.

Geoffrey R. Elton, Reform and Reformation: England 1509-1558 (London: Edward Arnold (Pubs.) Ltd., 1977), p. 355. Regarding the reforms under Northumberland, Elton writes:

The most notable administrative reforms undertaken touched the Crown's finances, ruined by war, debasement, extravagance and corruption . . Though the earl himself clearly understood little of the complex issues involved, other members of the administration did, especially Smith, Cecil and winchester. 
of Tudor coinage and the Great Debasement. ${ }^{3}$ Their concern, however, is primarily in ascertaining the exact amount of currency alteration through depreciation and debasement. They make little attempt to trace the origin of fiscal policy.

Thus there is a challenge to be met in attempting to recreate Edward's finances from the bits and pieces of evidence available. To do so will add substance to the suggestion now being made by Hoak and Elton that Cecil played a key role in Northumberland's administration and that he was particularly effective in the reorganization of finance. Such a study also demonstrates that Cecil set policy. Contributing to this policy were ideas old and new. Some came to fruition; some remained on the drawing board. Some came from Thomas Gresham and Walter Mildmay, and some from Thomas Smith.

\section{TUDOR REVENUE}

Historians agree that Henry VIII's legacy to his son was a troubled realm. Pollard stated the situation succinctly: "Henry VIII inherited a stable throne, an overflowing treasury, and the affections of a united people. He undermined the first, he emptied the second and alienated the

${ }^{3}$ C. E. Challis, The Tudor Coinage (Manchester: Manchester University Press, 1978) and J. D. Gould, The Great Debasement (Oxford: Clarendon Press, 1970). 
third." 4 The empty treasury is the focus of our attention.

Prior to the Tudor era, Crown revenue had come primarily from the fruits of justice, the farming of demesne land, and feudal dues. In the late fifteenth century, the growth of London combined with improved means of travel and communication to allow the Crown to manage its growing properties from a central point--Westminster. The dissolution of the monasteries made famous by Henry VIII was in fact begun by Henry VII with a resultant increase in royal land which could be rented for a cash income. Henry VII further augmented the royal income by resurrecting old feudal dues and insisting on their payment. He was vigorous in collecting first fruits and tenths, enforcing customs duties, and in his policy toward escheats and forfeitures. Cromwell, in the 1530s, created new courts through which these sources were funnelled directly to the Crown. As agents of the Crown and instruments of the royal prerogative, the revenue courts followed the procedures of civil law. ${ }^{5}$ The King was free of the restraints of the common law and had by-passed Parliament as a source of revenue.

${ }^{4}$ A. F. Pollard, England Under Protector Somerset (1900; rpt. New York: Russell \& Russell, 1966), p. 40.

${ }^{5}$ W. C. Richardson, Tudor Chamber Administration 14851547 (Baton Rouge: Louisiana State University Press, 1952), p. 352. To resolve ambiguities in the courts' legal status, an Act of Parliament in 1552 empowered the King to change, dissolve or unite any of the revenue courts. This permitted the later consolidation of the courts. 
The new courts were the Courts of The Duchy of Lancaster, General Surveyors, First Fruits and Tenths, Wards and Liveries, and Augmentations. Each was a separate entity responsible to the King. These courts and the income derived through them were particularly important to the King in a period when Parliamentary subsidies were still considered to be extraordinary income, not a normal budgetary item for a King who, in theory, was expected to "live of his own." Henry VIII's problem was that he had private revenues and public responsibilities. In the sixteenth century, revenue sources lagged behind the growing needs of the state. 6 Figures show that at the end of Henry VIII's reign his ordinary income exceeded his ordinary expenses by $\pm 50,000$, a comfortable sum to put into the royal coffers. 7 However, the costs of wars in Scotland and France ran to $12,108,282$. These expenses were met in part by the sale of crown lands and the debasement of the coinage. Even so, Henry had a surplus debt of 1100,000 which at his death passed to his son. ${ }^{8}$ Henry's alienation of Crown lands worsened this by reducing the Crown's capital assets and thereby lowering

6ietz, "Finances of Edward VI and Mary," p. 81. War was not yet recognized as a national concern and it was expected that the King should raise funds for "his" war.

${ }^{7}$ Dietz, "Finances of Edward VI and Mary," p. 74. ${ }^{8}$ Pollard, England Under Protector Somerset, p. 45. 
its potential for long-term revenue. Thus the nine-year-old King Edward inherited man-sized financial problems which, in his short reign, were to prove almost insoluble.

\section{FINANCES UNDER SOMERSET}

Protector Somerset's eighteen month tenure of office was a turbulent period. There were rebellions in Cornwall and Norfolk reflecting religious and agrarian unrest respectively. His tentative steps toward Protestant reform satisfied few. The relaxation of treason laws opened the door for discussion and dissent as "radical" reforms from the Continent arrived in England, intensifying religious controversy. In addition, somerset's misguided attempts to ease economic unrest by investigating enclosures alienated the gentry and raised false hopes among the peasants. Somerset's determination to continue the war with Scotland strained England's finances to a desperate point. Whether or not we accept Bush's thesis that Somerset was moved not by idealism, but by an idée fixe, figures show that the war was prohibitively expensive. ${ }^{9}$

Administrative costs added to Somerset's financial problems. Gifts of land and cash were the customary rewards for service to the Crown. They were a major government

${ }^{9}$ Michael L. Bush, The Government Policy of Protector Somerset (London: Edward Arnold (Pubs.) Ltd., 1975), p. 33. 
expense. In addition, there were the innumerable small gifts such as those the King gave on New Year's Day. 10 Duplication of office, exemplified by the various revenue courts and several mints, raised the cost of government. This pattern, begun by Henry VIII, snowballed quickly. Between 1547 and 1552 , administrative costs doubled. ${ }^{11}$ This increase was part of the acute rise in prices which characterize the mid-century years.

Somerset took some steps toward financial reform, though these efforts too were inadequate to the need. Economies in the royal household were attempted. Suspected graft within the revenue courts and among the mintners sparked investigative commissions, one of which ultimately brought about the demise of Somerset's brother, Thomas Seymour, the Lord Admiral. Counterfeiting brought a sizable loss to the crown. In an effort to halt this practice, the largest silver coins, or testons, were recalled to the mint where they were to be exchanged at face value for coins of small denomination. ${ }^{12}$ Like much of Somerset's policy, this measure was not enforced. ${ }^{13}$ To curtail the spiralling cost

${ }^{10}$ John C. Nichols, ed. Literary Remains of Edward the Sixth (New York: Burt Franklin, 1857), I, P. CCcvii.

${ }^{11}$ Elton, Reform and Reformation, p. 356.

12 A. E. Feaveryear, The Pound Sterling (London: Oxford University Press, 1931), p. 59.

13 Feaveryear, The pound sterling. 
of commodities, prices were set for grain, butter, cheese and poultry. These controls brought little abatement in prices and caused public resentment. During the summer of 1549, Somerset chose to ignore the advice of his Council and resorted to a new debasement of the coinage. ${ }^{14}$ Desperately pressed as Somerset was, it is easy to understand the attraction of this procedure. In the summer of 1549 the market price for silver was such that the Crown made a gross profit of $9 \mathrm{~s} .2 \mathrm{~d}$. on every pound of silver coined. ${ }^{15}$

Although it is clear that Somerset's decision to debase the coinage was dictated primarily by the urgency of his need for money, economists now suggest the possibility of a comprehensive plan. C. E. Challis believes that the conversion of the testons was expedited when Somerset realized that the price of silver was increasing and the supply of buliion diminishing, thereby dimming the prospect for continued profits at the mint. ${ }^{16}$ This indeed proved to be

${ }^{14}$ Challis, The Tudor Coinage, p. 248. Debasement of the coinage is considered fiscal exploitation because it makes a profit for the Crown by divorcing the intrinsic value of the coinage from its face value and uses the difference between the two for revenue. This practice is to be distinguished from depreciation, a phenomenon widespread in sixteenth century Europe, which brought a reduction in the metallic content of coins as dictated by rising bullion prices.

For the specifics of this Conciliar advice, see S.P. Edw. VI, 10/7/38 f. 96 .

15 Feaveryear, The Pound Sterling.

${ }^{16}$ Gould, The Great Debasement, p. 197. 
the case for, within a year, profits at the mint dropped to 3s. 4d. per silver pound coined. $17 \mathrm{~J}$. D. Gould speculates that the demonitization of the testons was envisioned as the first stage of a two-tiered system of coinage. ${ }^{18}$ The debased coins were to be confined to those of small denomination and those of larger denomination would provide a currency of "good" coin for wholesale and overseas trade. Although Gould makes no mention of the letter Smith wrote to Somerset in June 1549 detailing the possible sources of revenue for the next few months, it contains a reference which could be interpreted to support the Gould two-tier theory. Smith writes that the mints at York and Canterbury could produce "brass money" in small denominations "as pence, half pence and two pence, for the lack of bullion, to ease the poor people."19 This is also evidence that the Council was concerned about the severe hardships which inflation inflicted upon "the poor people."

In economic analysis, intentions are not matters of consequence. What counts are the resuits of the alteration of the coinage, begun in February 1548 with the conversion of the old testons and continued through the 1549 debasement. Prices escalated at an even faster pace. As a consequence

\footnotetext{
17 Feaveryear, The Pound Sterling.

18 Gould, The Great Debasement.

${ }^{19}$ Smith to Somerset. S.P. Edw. VI. 10/7/38, f. 96.
} 
of increased inflation, there was widespread resentment against the government. A loss of confidence in the coinage abroad caused English currency to fall on the Flanders exchange. The King's debts remained unpaid and it became necessary to borrow money in Flanders at $14 \%$, a stiff rate reflecting the low opinion of the English government and its currency. Thus upon Somerset's fall from power in October 1549, prices were rising, the debt unpaid, and the war with Scotland continued to drain the treasury. This was the state of the realm when John Dudley, Earl of Warwick, became President of the Council and King Edward's principal minister.

THE NORTHUMBERLAND YEARS 1550-1553

Somerset's failure to hold his position was the result of a loss of confidence in him, in his policy, and in his government. Whether or not he was a champion of liberal ideals as suggested by Pollard, Somerset was a poor leader of men. He did not listen to advice, made unilateral decisions, and adopted a lenient stance which made him appear weak and ineffective. These personal traits made the Council despair of his leadership and for the order of the realm. Outside this immediate circle, the landed interests in Parliament shared this fear of disorder because it threatened their economic and social security. The aura of unrest throughout the country was expressed in a general 
antipathy toward the government and in the two rebellions in the summer of 1549. There had, in effect, been a breakdown in the administration of government. A system of government which still required a strong head of the body politic suffered when a child king was forced to rely upon a minister who lacked the capacity to rule alone and who failed to utilize the Council as a supplemental instrument of government.

It is not surprising that Somerset's fall was followed by a period of reaction under Northumberland. After the coup d'etat which sent Somerset, Smith, Cecil and others to the Tower in October, Parliament did not reconvene until November 4. It then met until February 1, 1549/50. During this period attention was directed primarily toward religious matters, but it is clear that Warwick and the Commons were determined to reverse Somerset's policies. Parliament repealed the final payment of the tax on sheep, wool and cloth and provided a compensating subsidy instead. 20 In addition to this expression of opposition to Somerset's enclosure policy, Parliament took steps to maintain the security of the realm. It created permanent representatives in the counties as "lords lieutenant" to maintain law and

20 Dietz, "Finances of Edward VI and Mary," p. 85. 
order. $^{21}$ Warwick himself chose to become Lord President of the Council rather than Lord Protector. He wooed the Protestant left in order to consolidate his position as leader of the Council. Cecil was released from the Tower on January 25. Smith and Somerset followed in February. By April Somerset was back on the Council. This return may have resulted from Warwick's conciliatory desire to work with Somerset or from pressure exerted by the Council's liberal element which was still loyal to somerset. In any event, Warwick remained absent from Council meetings during the spring, guarding his position and garnering supporters. His immediate objective was an end to the war with Scotland. This was accomplished with the Treaty of Boulogne on March 29, 1550. A summer uprising met firm opposition from the new shire lieutenants. Thus the initial months of Warwick's regime demonstrate solutions to immediate problems within a comprehensive plan to restore order. Warwick had to stop the financial drain of the Scottish war, manipulate Council membership to secure his position, and tighten the reins of government.

${ }^{21}$. F. Tytler, England Under the Reigns of Edward the Sixth and Mary (Iondon: Richard Bentley, 1839), p. 186. Tytler prints a letter written by Smith to Cecil 19 July 1549 in which he proposes that "letters directed to one or more special men of trust in every shire" be authorized to "take and lead away the stirrers." Here is an example of an idea advanced by Smith to Cecil which later was realized in policy. Unfortunately, there is no documentation to prove that this interchange resulted in the creation of the "lords lieutenant." Such a course must once again be described as "probable." 
On september 5, 1550, William Cecil was sworn as King's Secretary, the position Smith had held under somerset. 22 His activities during the period after his release from the Tower and his appointment as Secretary are not recorded. Alliances within the Council were fluid during these months and Cecil appears to have maintained his connection with Somerset while establishing rapport with Warwick. Smith meanwhile made no attempt to reactivate his tie with Somerset and retired to the country where, in 1550, he purchased the manor at Ankerwicke overlooking the fields of Runnymede. 23 From september 1550, Cecil's regular attendance at Privy Council meetings, his frequent endorsement of documents and the vast number of letters and suits addressed to him indicate that he began immediately to develop the Secretaryship along Cromwellian lines. Once again this office became the key administrative post in the government. 24

$$
\begin{aligned}
& 22 \text { A.P.C., III, p. } 118 . \\
& { }^{23} \text { Cal. Pat. Rolls, Edw. VI, III, p. } 407 .
\end{aligned}
$$

${ }^{24}$ In October 1549, Dr. Nicholas Wotton replaced Smith as Secretary and retained the position until september 1550, when Cecil was appointed to the office. Petre remained Secretary throughout Edward's reign. The office had been divided between two equals by Henry VIII and thus the term Principal Secretary is ambiguous. Because he had held the office since 1544, Petre was no doubt considered the senior officer but historians now use the term "Principal Secretary" for Paget, Petre, Wotton, Smith and Cecil. See Dale E. Hoak, The King's Council in the Reign of Edward VI (Cambridge: Cambridge University Press, 1976), p. 23 and F. M. Evans, The Principal Secretary of State (New York: Barnes and Noble, 1923), p. 40 . 
While secretary to Somerset, Cecil had been close to the government's financial matters. If not a theorist as was Sir Thomas Smith, Cecil knew the administrative side of fiscal policy. The close contact between somerset, Smith and Cecil during 1549 certainly would have resulted in an exchange of information between the two secretaries. ${ }^{25}$ The tone and subject matter of Smith's letter to Cecil, written in July 1549, confirms the fact of their friendship and indicates a mutual participation in government affairs. Cecil was considered knowledgeable about currency, foreign exchange and the routine matters of the domestic economy. Cecil, Sir Walter Mildmay, Sir William Paulet and Sir Thomas Gresham made up the official financial "brain trust" under Warwick, or the Duke of Northumberland as he became on October 11, 1551.26 These men, rather than Northumberland, formulated financial policy. 27 once underway, this activity centered upon administrative reform and restoration of the coinage.

\section{${ }^{25}$ At this time Smith was King's secretary and Cecil} was Sonerset's personal secretary, a member of his household and not of the government.

\section{${ }^{26}$ Conyers Read, Mr. Secretary and Queen Elizabeth} (London: Jonathan Cape, 1960), p. 74. At this same ceremony, Cecil received his knighthood and Paulet became Marquess of Winchester.

27 H.M.C. Salisbury Manuscripts, I, p. 86. 16 June 1551. Warwick, in a letter to the council, stated that he understood little about finance. 
Administrative Reforms

The administrative reforms of the Northumberland era reveal Cecil's growing prominence. If there were no new magic cures, the significance of these measures lies in the vigor and thoroughness with which they were undertaken. This efficient Conciliar activity was directed by Cecil. Smith's influence here is general rather than specific. His earlier suggestions of increasing the sale of Crown land and refinancing Crown debt were indeed followed, but these were hardly original ideas. Smith's greater contribution to administrative reform lies in Cecil's comprehensive approach to budgetary planning and his close attention to supervision. From the time of Cecil's assumption of responsibility for government finance, this long-range, methodical approach becomes evident. ${ }^{28}$ His objective was to obtain an accurate assessment of royal assets and liabilities. When this was accomplished, a plan to balance the two could be put into effect. Such a program required improved efficiency within the Council. To this end there was a reorganization of duties among the Councillors. All of this resulted in a

${ }^{28}$ Examples of this attention to detail within a comprehensive plan can be found in S.P. Edw. VI 10/15. Folios 88 and 92 , written by Cecil, are calculations of foreign and domestic debt and possible revenue sources such as the sale of "shippes" and "ye coynage of ye Church plate." These "Notes of the King's Majesty's Dette" are reinforced by records of Cecil's attendance at almost every Privy Council meeting during 1552, except between March 25 and April 24 when illness kept him away. A.P.C., IV, pp. 4-289. 
systematic approach to finance which contrasts sharply with the stopgap measures of the protectorate.

Memoranda in the King's Journal illustrate the direction of Conciliar discussion. In March, Edward notes the partition of duties.

It was agreed that for better dispach of things, certein of the councel, with others joined with them, should overloke the penal laws, and put certein of them in execution. Other shuld aunswere sutars; other shuld oversee my revenues, and the ordre of them; and also the suparfluouse, and the payments heretofore made; other shuld have commission for taking away superfluouse bulwakes. 29

This assignment of responsibility provided the information which Cecil used to prepare a "memorial as to ways and means" in October. ${ }^{30}$ The effort to bring income and expense into balance led to the usual economies: "diminishing the charges of the pensionars' table, discharging in. th'admiralte, provision to be made for the wardrobe, wherby the charg may be the lesse..." 31

It is clear that the council resorted to the old means of economizing in the proposals for rețenchment, enforcement of penal laws, sale of crown land and investigative commissions. However, they were now undertaken with a definite sense of "thorough." This was particularly true of

$$
\begin{aligned}
& 29 \text { Nichols, Literary Remains, II, p. } 403 . \\
& 30 \text { Nichols, Literary Remains, II, p. } 500 . \\
& 31_{\text {Nichols, Literary Remains, II, p. } 543 .}
\end{aligned}
$$


the commissions of inquiry into the remaining ecclesiastical sources of revenue and those investigating the mints and revenue courts.

The Calendar of Patent Rolls reveals that from the beginning of Edward's reign, commissions had been warranted to investigate everything from lunatics to church laws. Indicative of their high level of efficiency is commissioners' ability to correct a long-standing abuse. They were "able to ensure that concealments and arrearages amounting to the handsome figure of $\pm 27,7829 \mathrm{~s} .4 \mathrm{~d}$. helped to fill the coffers of the Crown rather than augmenting the personal fortune of an influential subject." 32 These commissions were empowered to audit the "leager bokes" of the court or agency involved so that the Crown would know "how the money has been spent and to punish offenders." 33 The design of the commissions was to "bringe in with all diligence a booke of all suche debtes and arreraeiges as arr due to the Kinges Majestie," to survey treasury books, investigate officials, and bring any felons to justice. ${ }^{34}$ The latter procedure accomplished the double benefit of terminating concealments and producing increased revenue through the exaction of

${ }^{32}$ C. E. Challis, "The Debasement of the Coinage 15421551," Ec.H.R., 2nd series, XXV (May 1972), p. 448.

${ }^{33}$ Cal. Pat. Rolls, Edw. VI, IV, p. 392.

${ }^{34}$ A.P.C. III, p. 228. 
fines. This, in fact, was an important motivation for enforcing the penal laws. From these commissions Cecil determined in October 1552 that the King had an outstanding debt of approximately $\pm 200,000.35$

An indication of the vast ecclesiastical holdings which had survived Henry VIII's dissolution is in the listing of "gilte plate, parcel gilte," and jewels which Sir Anthony Aucher, Master of the Jewel House, delivered to Sir Edmond Peckham at the mint. ${ }^{36}$ Sir Anthony made repeated deliveries of Church plate which was then melted down and added to the bullion reserve or coined. The extent to which the country was stripped of its decorative metals at this time is underscored by the fact that even a number of silver and gold book bindings from Edward's library went into the melting pot. Another way in which the Church was made to contribute to royal revenue was, of course, confiscation of its land. Upon becoming Bishop of Winchester in 1551, John Ponet gave over the entire diocese in exchange for an annuity. Through this same procedure, the Crown acquired other great sees. The sale of Chantry lands followed this same pattern.

Commissions investigating fraudulent officials served both a financial and a political purpose. Thomas seymour's

$$
\begin{aligned}
& 35 \text { Nichols, Iiterary Remains, II, p. } 550 .
\end{aligned}
$$

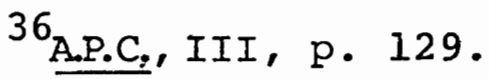


fall was the by-product of an investigation of Sir William Sharington of the Bristol mint conducted by Smith in 1548 . Sir William Paget, officially the target of a financial inquiry, was actually pursued because he was a political enemy of Northumberland. Anticipation of his fine as an addition to the Royal coffer was duly noted by cecil on his balance sheet for November 1552.37

The most famous and the most important of these many commissions was established March 23, 1552 to survey the revenue courts. 38 The report of this commission, made in December 1552, suggested three plans for the amalgamation of the revenue courts. The program was designed to reduce the expense of duplicate offices, a real factor in the increase of government costs which had been so notable during Edward's reign.

This commission consisted of six members, of whom Sir Walter Mildmay was the only "financial expert." 39 The conception of this commission as well as its membership may well have been Edward's, in consultation with Cecil, for his papers contain a list of appointments for persons who "shal

${ }^{37}$ S.P. Edw. VI, 10/15/92.

${ }^{38}$ Cal. Pat. Rolls, Edw. VI, IV, p. 353. See Appendix III.

${ }^{39}$ Elton, Reform and Reformation, p. 357 and The Tudor Revolution in Government (Cambridge: Cambridge University Press, 1969), p. 230. The Commission lists nine members, three of whom (Wrothe, Petre and Gosnolde) did not actually serve. 
loke to the state of all the courtes, specially the new erected courtes, as the augmentation, the first frutes and tenthes, the wardes . . and thereof shal make certificat, which they shall deliver:" 40

When delivered at the end of the year, the report gave a full account of royal revenue for the year 1551. Then came a listing of possible sources of increased revenue and means of reducing administrative costs. To accomplish this reduction, various proposals for fusing the courts were set forth. The Courts of Augmentation and the Duchy of Lancaster could be joined for management of the King's lands, revenue to be collected by local sheriffs. Ultimately the separate courts could be incorporated into Exchequer, thus reducing the number of officials and centralizing administration. ${ }^{41}$ One unfortunate aspect of the timing of Edward's death was its interruption of the revenue court reform. Some reform was effected under Mary. However, the reluctance of officials to give up their lucrative positions and the absence of a Cecil to push for completion of this plan impeded the process of reorganization. There was also an understandable hesitancy by the Crown to give up a court, such as the Court of Wards, which was a powerful instrument of the prerogative.

${ }^{40}$ Nichols, Literary Remains, II, p. 501.

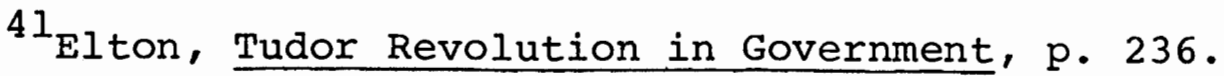


What was accomplished in Mary's reign, however, was the product of Edwardian policy. 42

The result of the investigation and partial consolidation of the revenue courts was a reduction in the staffing of these courts and a general move toward efficiency. Elton, of course, sees this as a further development of Cromwellian reform. The significance of the reform lies, rather in its move toward simplification and centralization.

Both the fiscal and administrative reforms of the last eighteen months of Edward's reign reflect the existence of a comprehensive plan to accomplish long-term and short-term goals. The sophisticated fiscal concepts which determined the valuation of the coinage and rate at the Antwerp exchange can be attributed to only a few possible sources. The competence of the administrative reforms can be more directly traced to Cecil, whose private notes and endorsements of official records leave little doubt as to his central position on the Council, as advisor to Edward, and as formulator of Northumberland's policies.

Restoration of the Coinage

Restoration of the coinage was the key element in the reform program. It required two years and some painful lessons to accomplish even a partial restoration; in fact, the coinage remained a problem which cecil tackled once

42 Elton, Reform and Reformation, p. 356. 
again in Elizabeth's reign.

Just as it had been for some time, the government in 1551 was faced with inflation, debt, expenses that exceeded income, and hostility from the populace. Northumberland's challenge was to curb inflation, pay the King's debts and reduce expenses, and in this manner restore public confidence. In the policy of coinage debasement, therefore, it is possible to discern a twofold, seemingly contradictory plan. In short, debasement was seen as a means to secure quick gains in order to pay off debts, then the government would call down the currency to a low valuation, thereby restoring its integrity. This may appear the robbing of Peter to pay Paul. Indeed, historians have not appreciated the reform aspect of this policy and have emphasized Northumberland's debasement as' one more irresponsible milking of the treasury. ${ }^{43}$ However, a broad view of the government's overall financial policy reveals a much more comprehensive concept. The idea was to debase the coinage in order to reform it. 44 Rather than the scheme of the greedy Duke, debasement was part of a deflationary policy which reflects sophisticated thought.

Historians have speculated on the level of economic

43 Wilbur K. Jordan, Edward VI: The Threshold of Power (Cambridge, Mass.: The Belknap Press, 1970), p. 460.

${ }^{44}$ Feaveryear, The Pound Sterling, p. 61 . 
understanding in England at mid-century. Elton believes that "by 1550 Smith's opinion that inflation must be cured by reversing the disastrous experiment in debasement had become common property." 45 Along the same line, Dietz wrote :

The evils of the debasement of the coinage, the exportation of all the good money, especially the gold of the country, and the adverse foreign exchange, together with the effect of the debasement on prices, were clearly recognized by writers, merchants, and the popular preachers. 46

As examples, Dietz cites John Hales as the author of the Discourse, William Lane's letter to William Cecil and Bishop Latimer's sermons. ${ }^{47}$ Although all writers at midcentury were aware of the connection between the altered coin and the lower exchange rate, only Sir Thomas Smith's writing evinces a clear understanding of the relationship between debased coinage, rising prices, exchange rates, and the long-term consequences to merchants who bought high and sold low. William Lane blamed the fallen exchange as the "father of all dearth" and Bishop Latimer flirted with sedition by commenting on the "pretty little shilling."

${ }^{45}$ Elton, Reform and Reformation, p. 355.

${ }^{46}$ Dietz, "Finances of Edward VI and Mary," p. 94.

${ }^{47}$ Until Mary Dewar established Smith's authorship of A Discourse of the Commonweal of this Realm of England to the satisfaction of almost all contemporary historians, John Hales was considered a possible author of this anonymous work. At the time Dietz wrote, Hales was the front runner. 
None of the examples cited by Dietz, except the Discourse which Smith, not Hales, wrote, gives evidence for Elton's contention that Smith's ideas were common property. There was in reality little sophisticated comprehension of the consequences of debasement, just as few men understood the factors which determined the exchange rate. Elton's statement might be correctly applied only to that inner circle of advisors--Cecil, Mildmay, Gresham and perhaps Paulet. 48 The Council's faltering course in financial reform must be approached within this context of limited understanding. This fact, when combined with the pressing need for money, explains the hesitancy and error of the Council's program in 1551. It is in sharp contrast to that initiated in the spring of 1552 when Northumberland formally turned financial matters over to William Cecil. Thus there are actually two phases to financial policy under Northumberland. Their differences are sufficient to warrant detailing the activities of 1551 and 1552 .

1551. A letter from Bishop Hooper to Cecil dated

17 April 1551 sets the contemporary scene.

For the love and tender mercy of God, persuade and cause some order to be taken upon the price of things, or else the ire of God will shortly punish. All things be here so dear, that the most part of people lacketh, and yet more will lack necessary food. . .

${ }^{48}$ Elton, Reform and Reformation, p. 358. Although Paulet was Lord Treasurer and enjoyed a long term as nominal head of finance, he was primarily an administrator. There is little evidence to indicate that he ever contributed ideas to set policy. 
All pastures and breeding of cattle is turned into sheep's meat, and they be not kept to be brought to the market, but to bear wool, and profit only to their master. Master secretary, for the passion of Christ take the fear of God and a bold stomach to speak herein for a redress, and that the goods of every shire be not thus wrested, and taken into few men's hands. If it continued, the wealth and strength of the realm must needs perish.

So much as have more than enough, buyeth when things be good cheap, to sell afterwards dear. . . I can pexceive none other here but love and reverence among the people to the King's Majesty, and to the laws; but, Mr. Secretary, it is the magistrates, and their own doings, that shall most commend them, and win love of the people. Ye know what a grievous and extreme - yea, in manner unruly - evil hunger is. 49

This lengthy quotation illustrates contemporary thought. Enclosures were blamed for inflation. Obedience and loyalty to the King were taken for granted and men looked to the government for redress. The threat of rebellion from a hungry populace was real.

This was the state of affairs throughout the realm when, on April 10, 1551, the Council first took up the subject of the coinage. Edward recorded the discussion in his Journal.

Also it was apointed to make twentythousand pound weight for necessite somewhat basser, to get gaines 160,000 pound clere, by wich the det of the realme might be paid, the countrie defended from any soudain attempt, and the coine amendid.50

${ }^{49}$ Tytler, England Under the Reigns of Edward the Sixth and Mary, $I, p .364$.

${ }^{50}$ Nichols, Literary Remains, II, p. 313. 
The twofold element of the plan is clear from Edward's statement. A last profit from the mint would clear debts, provide a bit of reserve against emergency, and bring a restitution of the coinage. Improving the coin was the object of the long-term plan. The short-term goal required minting debased coin in order to realize a profit between the market price paid for the silver and the rate at which it was issued. This would provide the government with money to pay its current expenses and to liquidate the Flemish loans.

The Council's plan contained the following provisions. Enough silver was to be minted at $3 \mathrm{oz}$. fineness to provide the government with a net profit of $\pm 160,000$. After the coin had been distributed, it was to be called down in two stages, first to $2 / 3$ and then to $1 / 2$ face value. ${ }^{51}$ The existing stock of bullion could be coined into money with a high silver content and used to purchase old "testerns" as they were turned in for redemption at the mint. These in turn would provide the funds for purchase by the mint of base money at half its face value. In time, the coinage would be restored. 52

On April 30, 1551 a proclamation went out announcing

$51_{\text {Feaveryear, The Pound Sterling, p. } 61 .}$

52 H.M.C. Salisbury Manuscripts, I, p. 86. Warwick to Council 16 June 1551 . 
that on the last day of August, the shilling (or teston) would be worth $9 \mathrm{~d}$. and the groat $3 \mathrm{~d} .^{53}$ The mint then began to issue the new coins. However, the announcement that the coins would subsequently be called down created a panic. Good money disappeared from circulation, commodity prices rose, and the exchange rate for English currency dropped. The debased coinage produced a short-term advantage for English merchants who bought wool "cheap" and could temporarily reap greater profits selling at the old price in Flanders. When the domestic price rose, they reduced their selling prices and continued to make some gain. This produced a glut on the Flanders wool market and a financial crisis in June 1551. A letter written to the Council from Brussels by Sir Thomas Chamberlayne on June 7 outlines the situation.

- . . . It appeareth not here that the calling down the money with you doth help the exchange; for, since the same was known of, the exchange is fallen from fifteen shillings to fourteen shillings for a pound of our money which is far from thirty shillings of this money that I have known delivered for twenty shillings of ours; whereby it may well appear that the exchange is but merchants' practice; with how little they regard the common weal, for advancement of their private lucre, I think the world doth see.

And truly it is strange to hear that at this day the strangers, as well as our merchants, do well here of our commodities for 50, 52, and 48, that cost 60 and upwards; as appeareth by our merchants, that take the shilling for 12d. and the grote for $4 \mathrm{~d}$. that he is not able to go through with such loss as to buy for 60 and sell for 50, for daily they play bankrupt; 
therefore, there must be some mystery in the matter. I pray God it may be discovered, to the weal of our realm. 54

Chamberlayne's letter reflected the fact that in June 1551, the pound had reached its lowest point on the Flanders exchange. According to Thomas Gresham, the pound was then valued at 13s. $4 d^{55}$ Commodity prices in England had doubled their 1540 level, so that the purchasing power of English currency had been reduced by half. Chamberlayne's letter also indicates that again the symptoms of financial ills were clearly apprehended. But, by blaming the fluctuations on merchant's manipulations, Chamberlayne was among the many who misunderstood the interrelationship of the exchange, commodity prices, the market price of silver, and the intangible but real influence of public opinion.

Public outcry was sufficient to worry the Council. On June 15, the board altered its original schedule and ordered the mint to stop making the $3 \mathrm{oz}$. silver coins. The reserve bullion was "to remayne as a threasure for the King." 56 Despite this resolution, the old problem of war expense demanded that coinage be resumed briefly to cover fortification costs at Berwick and Calais. Then, on 17 July 1551,

54 Tytler, England Under the Reigns of Edward the Sixth and Mary, $I, p .380$.

${ }^{55}$ Feaveryear, The Pound Sterling, p. 61.

56 A.P.C., III, p. 305 . 
recoinage was permanently suspended. The total involved was $\pm 130,000$ or $\pm 30,000$ below the original forecast. 57 Meanwhile, on July 8 , the date for the initial revaluation had been moved ahead to make the shilling current at $9 \mathrm{~d}$. and the groat $3 d .58$ This proclamation was followed by another on August 17 which brought the shilling to $6 \mathrm{~d}$. and the groat to 2d. to achieve "more fyneness." In an effort to rally public opinion, this proclamation explained the change in dates.

For as much as excessive prices "(which of reason shold have growen lesse as the coyne is amendid)" are since then rather, by greed of those who make their gain buying and selling, increased to the intolerable burden of his subjects especially "those of the poore sort" for the remedy whereof "nothing is thought more avaliable (sic) then the spedie reducing of the sayd coyne more nere his just fynesse. 59

So the period of debasement ended as the King called for final suspension "by advice of his Privy Council, esteeming the common wealth more than the profit coming to him by the baseness of the coin." 60

\section{7..P.C., III, p. 316 .}

${ }^{58}$ Cal. Pat. Rolls, Edw. VI, IV, p. 131.

${ }^{59}$ Cal. Pat. Rolls, Edw. VI, IV.

${ }^{60} \mathrm{Cal}$. Pat. Rolls, Edw. VI, IV. Privy Council records (A.P.C., III) from April through October 1551 show that Cecil attended meetings spasmodically during this period and a much more regular attendance after october, the month when Northumberland achieved political dominance. For example, both Cecil and Petre were absent from the Council meeting April 29, 1551 which determined that the shilling was to drop to 9d. (A.P.C,. III, p. 305) and yet the proclamation 
Although corrective steps had been taken, discussion of the problem continued in the Council. Entries in the King's Journal during September and October note "deliberacion touching the coyne."61 Two measures were decided upon. A few of the old "fine" testons remained in circulation. These were to be recalled by a "Proclamacion signed touching the calling in of testornes and grotes, that they that list might cum to the minte and have fine silver of twelve pence for two testornes." 62 In addition, new coins of increased purity were to be minted at $11 \mathrm{oz}$. fine. These would be exchanged for old coins, fine or based, which the mint would purchase for $6 \mathrm{~d}$. Apparently the profit incentive was insufficient, for there was little public response and few coins were exchanged. The problem continued to be studied in the Council during the winter.

During these winter months, the Council also had other concerns. Warwick's dominance of the board was assured by October 1551. On October 11, Warwick became the Duke of Northumberland and Cecil was knighted. Cecil's growing importance on the Council as Northumberland's right-hand

announcing this change was endorsed by Cecil on May 28, 1551 (H.M.C. Salisbury Manuscripts, I, p. 88), a routine secretarial task. Since matters to be discussed in Council were usually decided prior to meetings and the secretaries often had business away from Court, it is difficult to connect a minister's attendance with his actual influence on policies determined in Council.

${ }^{61}$ Nichols, Literary Remains, II, pp. $342,344,346,353$. ${ }^{62}$ Nichols, Literary Remains, II, p. 353. October 13, 1551. 
man shows that he had earned the confidence of both Edward and Northumberland. On October 15, the Duke of Somerset was arrested for plotting against Northumberland's life. This act confirmed the triumph of the Northumberland faction within the Council. Cecil's knighthood may have been the reward for allegiance to Northumberland during the struggle for power. 63 As factionalism increased within the council, Warwick's opponents had been removed. Paget was accused of financial indiscretion, fined and disgraced. Rich mishandled the Great seal and was deprived of the Lord Chancellorship. Bishop Tunstall of Durham was imprisoned and Bishop Gardiner removed from the see of Winchester. This was indeed a period of turmoil and struggle for power. The Pollard school sees the ruin of Somerset as "a mere detail in the plan of Warwick's operations" to achieve a position of supreme power. 64 Although Northumberland himself later admitted that he had procured Somerset's death unjustly, Hoak points out that the Duke had become aware that his position was being undermined by somerset, who was

${ }^{63}$ John Patrick Henderson, "Sir William Paulet, Marquess of Winchester, A Tudor Time-Server," Diss. St. Louis University 1969, p. 453. See also Calendar of State Papers, Spanish, I, p. 393. Jehan Scheyfve reported in November that "It is believed that secretary Cecil, formerly Somerset's secretary, first got wind of the plot..."

${ }^{64}$ pollard, England Under Protector Somerset, p. 284. 
moved by jealousy and a personal enmity for the Lord President. 65 Regardless of who may be the good or bad Duke, this must have been a period when the Council was distracted by internal dissension. This came to an end January 22, 1552 when Edward Seymour, Duke of Somerset, was executed on Tower Hill. Northumberland had triumphed.

1552. By March 1552, the domestic political scene was sufficiently settled to allow the Council to turn its attention once again to finances. Cecil's acknowledged position as Northumberland's principal administrator was further confirmed when the Lord President turned responsibility for government finance over to him. ${ }^{66}$ Cecil now became a formulator of policy. ${ }^{67}$ From this point, constructive measures indicate a steady hand at the helm. This came none to soon, for during the summer the King's Treasury was frequently empty. Recognizing at last that real steps toward reform were imperative, the Council set about further restoration of the coinage, repayment of the Flemish loans, manipulation of the Flanders exchange to bolster English currency, as well as the administrative reforms and

${ }^{65}$ Hoak, The King's Council, p. 74.

${ }^{66}$ Dietz, "Finances of Edward VI and Mary," p. 97.

67 This is the date from which official and private memoranda in Cecil's hand show his widespread activities and particular attention to financial matters. See S.P. Edw. VI 10/14 and S.P. Edw. VI 10/15. 
economies. Ultimately, in 1553, these heroic measures produced a fall in prices.

On May 23, 1552 Privy Council minutes record:

A letter to Sir Walter Mildmay and Sir Edmond Pecham (sic) to send hither with diligince a parfaict certificat in writing of the proportion articles and thother thinges requisite for the standard ix ounces fyne that was in the tyme of the Kinges Majestie deceassed. 68

A Council directive of this kind indicates the way in which the Council could utilize the service of experienced officials. Peckham was in charge of the Tower mint and Mildmay was a seasoned investigator who served on the many revenue commissions. Neither, however, was a theorist who could have formulated an overall plan to restore the currency. They were simply instruments of the Council who were instructed to report on the metallic content of coin prior to the first debasement. Once the Council had decided to increase the standard of fineness, new coins $11 \mathrm{oz}$. fine and weighing $96 \mathrm{gr}$. (as opposed to the old ones of $80 \mathrm{gr}$. ) were rated at 5s. 5d. per ounce. New gold coins were also

68 A.P.C., IV, p. 57. See also Stanford Lehmberg, Sir Walter Mildmay and Tudor Government (Austin: University of Texas, 1964), pp. 30 and 32. Lehmberg (p. 30) mistakenly attributes this letter to 1551 and states: "It is likely that their report, now lost, recommended a return to the standard in use before 1543, a proportion finer than that stipulated by the Council. In August the value of the shilling was again called down, this time to $6 \mathrm{~d}$. . ." This was the depreciation which had occurred in August 1551, following Council discussion on May 6, 1551, correctly cited by Lehmberg. The desire to return to a finer coin was part of Cecil's program to restore the integrity of the currency to the "old standard" or as near that fineness as possible. 
introduced. This increase in the quality of the coins was designed to make their exchange for old ones at the mint more attractive. Self-interest or profit, a distinctive part of Sir Thomas Smith's economic theory, was therefore acknowledged as a legitimate incentive, to be used by the government to enhance the common weal. This modern approach stands in marked contrast to medieval teaching that greed was sinful. Human nature being what it is, the prospect of profit was sufficiently great that this time the government's plan took effect. The old coins were exchanged at the mint with the result that in 1552 the circulating currency all dated from Edward's reign. The volume of currency was reduced and commodity prices fell. 69 Thus during this year, the Council's attempt to curb inflation began to meet with success.

Throughout 1552 Privy Council records reveal the critical state of the King's finances. On May 10, for example, Augmentations was instructed to make a payment and told that "if he does not have the money, he must try to get it from Receiver's." 70 There were frequent instructions to the revenue courts to make reports of their cash balances and to "stay payments." This was a period of real belttightening and indicates that the Council had been made to

$$
\begin{aligned}
& { }^{69} \text { Feaveryear, The Pound sterling, p. } 66 \text {. } \\
& \text { 70.P.C., IV, p. } 42 \text {. }
\end{aligned}
$$


realize that constructive steps were absolutely necessary. Cecil, as Secretary, planned and supervised the implementation of these policies.

While the coinage was being restored at home, Gresham was at work in Flanders regulating the exchange so that the Flemish loans could be paid off. Both he and cecil recognized that good currency would restore public confidence and improve the exchange rate. They recognized also that repayment of the loans, which fell due at six-month intervals, was imperative if Edward's finances were to be improved. The situation was so desperate that the government was often unable to pay current expenses. The standing army which Northumberland had assembled the year before had to be disbanded because the King could not pay its wages. Together Cecil and Gresham arranged that the Aldermen of the City of London, the Merchants of the Staple, and the Merchant Adventurers would provide money to cover the Flemish loans. Gresham devised the scheme and Cecil convinced the merchants it would be to their ultimate advantage to participate. The success of their operation restored faith in English currency abroad, enabling Gresham to accomplish his objective on the exchange in Flanders. Through their joint efforts, Cecil and Gresham liquidated the King's debts. A letter from Gresham to Cecil dated March 1, 1559 and a memorial to Queen Elizabeth the same year recall these events. As for exsampell: the exchange in Kinge Edwardes time, when I beganne this practice was but 16s. Dyd I not 
raise it to $23 \mathrm{~s}$. , and paid his whole detts after 20s. and 22s.

- . And by the meanes I did nott only bringe the Kinges majestie your brother out off deptt, wherby I savid hime $v j$ or $v i j s$. upon the pounde, but savid his tresore within the reallme, as ther in $\mathrm{mr}$. secretary Sissille was most privie unto. 71

\section{CONCLUSION}

These, then, were the fiscal reforms of 1551 and 1552. They consisted of restoring the coinage first through debasement and then through issuing finer coins. This began a rebuilding of public confidence in the currency both at home and abroad. A strengthened English currency on the Flemish exchange resulted. These measures stopped inflation and brought some fall in prices. Reform had been slow in coming. Not only was their a shortage of financial expertise among the Council members. The year 1551 was marked by rivalry between the Somerset and Northumberland factions which impeded the progress of reform. This was also the time when Northumberland was restoring the Council as an administrative unit. ${ }^{72}$ Once Northumberland had achieved a secure position of leadership within the Council and had begun to utilize its capacity for the implementation of policy formed by sound advice, financial reformation became

\section{${ }^{71}$ Nichols, Literary Remains, II, p. 551.}

${ }^{72}$ As previously indicated, Hoak has shown that Northumberland began procedural reforms within the Privy Council in 1550, earlier than other historians have suggested. 
possible. These developments coincide with the rise of William Cecil as a Privy Councillor of consequence. 
CHAPTER VII

SMITH, CECII AND FINANCIAL POLICY

The mechanism by which aspiration becomes achievement can be demonstrated in the financial reforms of 1551-1552, reforms which we suggest resulted from the relationship between Sir Thomas Smith, Sir William Cecil and the Privy Council. Having shown that Cecil formulated Northumberland's financial policy and implemented it through the council, we contend that the source of Cecil's program was Sir Thomas Smith, whose ideas, passed on to Cecil informally outside the Council, appeared in Cecil's comprehensive and constructive approach to administrative reform and in his restoration of the coinage.

The same process of elimination that established Cecil as a man of consequence links Smith and Cecil as policy makers in the specific area of Edwardian finance. Clearly there were few men in the government, or indeed in the realm, who possessed a profound understanding of economics, a science in its infancy. The shift from debasement to restoration of the silver content in the currency required expert guidance. There were only a handful of men who could have provided such advice. Sir Edmund Peckham was an experienced financial bureaucrat whose career as Master of the 
Mint stretched from Henry VIII to Elizabeth. He was, however, no theorist. He was an obedient servant of the Crown who competently administered policy set by others. Sir William Paulet, Marquess of Winchester, is the classic example of a Tudor time-server. As Edward's Lord Treasurer, it would be expected that he might well have originated financial policy. This was not the case. ${ }^{1}$ The only evidence of creative thought in his career is his methodical acquisition of property and the protection of his lucrative offices during the amalgamation of the revenue courts under Mary. ${ }^{2}$ Sir Thomas Gresham certainly played a crucial role in salvaging the exchange rate of English currency and in conceiving the plan of repayment of the Flemish loans. However, there is no evidence that he was an influence on domestic financial policy. ${ }^{3}$ Sir Walter Mildmay was the key member of the Royal Commission of 1552 which investigated the revenue courts and on innumerable related commissions. 4

${ }^{1}$ John Patrick Henderson, "Sir William Paulet, Marquess of Winchester, A Tudor Time-Server," Diss. St. Louis University 1969.

2 Under Mary the proposals of the 1552 commission were partially realized by transferring the Courts of Augmentations and First Fruits and Tenths to the Exchequer.

3A. E. Feaveryear, The Pound Sterling (London: Oxford University Press, 1931), p. 73.

${ }^{4}$ There was great overlapping in the personnel of these commissions. The Duke of Northumberland served nominally on many. Some members were appointed solely to give social weight to the commission or as a mark of recognition from 
He was instrumental in forming the plan for revenue court reorganization and in the eventual realization of this plan. Although not a Privy Councillor, he was close to the center of government. Mildmay, however, was an administrator, not a fiscal expert and cannot be credited with originating policy.

of the experts and financial officers, only two remain who could have planned the reforms. They are Cecil and Smith. There is nothing in Cecil's background to indicate he acquired a sophisticated understanding of monetary policy on his own. Cecil had earned Northumberland's confidence by October 1551 and was the acting leader of the Council during the Duke's frequent absences from Court. As Secretary, he

Northumberland. In a footnote (p. 32) Lehmberg comments on the composition of the 1552 commission: "The intention of Northumberland and Edward VI seems to have been to make most of the members of the commission members of the Council with continuing responsibility for financial matters; a memorandum of 1553 lists forty councillors, of whom eight, including Mildmay, Cotton, Wrothe, Gosnolde and Bishops Thirlby and Nicholas Ridley, 'be now called into commission,' that is, to membership in the Council." Thịs quasi-conciliar status is supported by a list of "Names of the Counsell" which includes Mildmay, who was not actually a Councillor. See S.P. Edw. VI 10/14 f. 11 .

See also, W. C. Richardson, The Report of the Royal Commission of 1552 (Morgantown: West Virginia University Library, 1974), p. xxxiii. Although Lehmberg describes Mildmay's capacity as one of "executive secretary," Richardson stresses his supervisory and organizational role. That Mildmay was firmly under the Council's direction is clear from an order on september 22, 1552 that he bring the Commission report in as soon as it was finished. See A.P.C., IV, p. 128. Richardson lists Paulet, Cecil and Mildmay as the "progressives" on the Council advocating reform. 
occupied the key position on the Council. Always careful to act through the Council, Cecil effectively determined Edwardian financial policy. How did he know what steps to take? He was certainly well-educated and learned quickly from experience. Though his interests and accomplishments were wide, he approached problems of government from the pragmatic position of administrator. His was not a scholar's mind. His gift was the ability to learn from others and from experience, and to translate this knowledge into action. For ideas on policy, he must have turned to an acknowledged expert on fiscal matters. That expert was probably sir Thomas Smith.

Sir Thomas Smith has come down in history as "a grave and learned man" and not much more. Those who have heard of him at all, know him as perhaps the finest scholar of his day, but one who never rose to the forefront as a politician, and who therefore made no impact on policy. We know some of the reasons for his obscurity. It remains to reveal him as a figure of consequence. Exploring his friendship and continued contact with Cecil makes this possible.

Elizabeth's coinage reform of 1560 provides insight into Edward's reform of 1552. In $1626 \mathrm{Sir}$ Robert cotton, noted antiquarian, argued against debasement of the coinage before Parliament.

When . - Queen Elizabeth came to the crown she was happy in council to amend that error of her father for in a memorial of the Lord Treasurer Burghley's hand I find that he and Sir Thomas Smith (a grave and 
learned man) advising the Queen that it was the honour of her crown and the true wealth of herself and people to reduce the standard to the ancient parity and purity of her grandfather Edward IV and that it was not the short ends of Wit nor starting holes of devices that can sustain the expense of a Monarch but sound and solid courses; for so are the words. She followed their advice. 5

On the basis of this evidence, Feaveryear concludes that Smith "was responsible for the advice that the new silver should be, not $11 \mathrm{oz}$. or $11 \mathrm{oz} .1 \mathrm{dwt}$. fine, but of the old sterling standard of England, $11 \mathrm{oz} .2$ dwt." 6 His reference is to Smith's advice regarding restoration of the coinage undertaken by a commission appointed in June 1560. Cecil was a member of this commission but at the time Smith did not hold political office. Obviously, while out of office,

${ }^{5}$ Mary Dewar, Sir Thomas Smith (London: The Athlone Press, 1964), p. 81. She cites Select Tracts and Documents Illustrative of English Monetary History 1626-1730, W. A. Shaw, ed. (London, 1935), p. 26 .

6Feaveryear, The Pound Sterling, p. 73. Feaveryear cites a note in $W$. Cunningham, The Growth of English Industry and Commerce (1910; rpt. New York: Augustus Kelley, 1968), p. 129. Cunningham in turn cites Strype's Life of Sir Thomas Smith (1820), p. 36 which states "according to the advice of Smith for good sterling money to be coined, those course testoon pieces were forbidden to be coined." Cunningham states further that "In Sir Robert Cotton's speech in the oxford Parliament of Charles $I$, the credit of advising the return to the old standard of fineness is given to Sir Thomas Smith, jointly with Burleigh . . . That he had give great attention to monetary questions is seen from his treatise, dedicated to Cecil, on the value of Roman coins." See especially Chapter VI, where the changes in the number of English coins minted from an ounce of silver are noted, and the history is carried down to 1562 . 
Smith had kept up his court contacts, particularly with Cecil. In 1560 Smith's advice resulted in policy. There is good reason to suppose that the same circumstances prevailed in 1552 .

All evidence indicates that Smith and Cecil maintained their friendship from Cambridge days until Smith's death in 1577. In Edward's reign they were brought together on official government business, on college matters, and on social occasions. In January 1551, Smith and Cecil were key witnesses at Bishop Gardiner's trial and worked together on a commission called to investigate heresy. ${ }^{7}$ In May, Smith appeared before the Council to receive an appointment to the Marquess of Northampton's embassy to France and was issued a warrant for \pm 100 to cover his expenses. ${ }^{8}$ Although Smith conducted the negotiations for the Treaty of Angers successfully, this mission led to no new appointment. He spent the time developing his manor at Ankerwicke and carrying out his duties as Dean of Carlisle and Provost of Eton. He appears, however, to have been considered along with Sir John Mason and Sir Philip Hoby, for a mission to Charles $\mathrm{V}$ in May 1552, perhaps anticipating the rumored

${ }^{7}$ Cal. Pat. Rolls Edw. VI, III, p. 347 and A.P.C., III, pp. 268 and 270 .

${ }^{8}$ Dewar, Sir Thomas Smith, p. 72. 
attack planned by German princes in alliance with the French king. ${ }^{9}$ There is no evidence to show that this embassy materialized. A memorandum in Cecil's hand, dated 24 November 1552, notes a "Smythe letter concerning the samer matter."10 since this entry falls under the heading of matters regarding Ireland, where a mint had been established to coin Irish silver, one can guess that Smith's interest in both coinage and Irish colonization might have moved him to send a letter to the council on this subject. ${ }^{11}$ Smith, the civil lawyer, was also called upon by the Council during the fall to settle some merchant disputes. With such evidence, Strype, when writing Smith's biography in 1698, could properly conclude that "Smith, though not Secretary, yet seems all this reign to be much about the Court, employed in state-matters there."12 Thus throughout 1551 and 1552 there were opportunities for Smith and Cecil to exchange ideas on matters of mutual interest and concern, including the financial problems of the realm. The acuteness of those problems

$$
\begin{aligned}
& { }^{9} \text { S.P. Edw. VI, 10/14, f. } 76 . \\
& { }^{10} \text { S.P. Edw. VI, 10/15, f. } 107 .
\end{aligned}
$$

${ }^{11}$ For background on Irish mint, see James A. Froude, History of England (1862-70; rpt. New York: AMS Press, 1969), 5, p. 435. Smith had long been interested in Ireland and attempted a "plantation" there in the 1570s.

12 John Strype, "The Life of the Learned Sir Thomas Smith," Works (Oxford: Clarendon Press, 1820), 25, p. 45. 
was certainly keenly felt by Cecil, whose responsibility they became in March 1552. It would have been natural to discuss them with Smith, the expert on coinage who had prepared a memorandum on this subject in October 1549 in connection with a transfer of mint profits to Somerset's allies. ${ }^{13}$ And, of course, Cecil knew of Smith's financial survey presented to Somerset in June 1549. Smith, then, was the obvious person to whom Cecil would have turned for financial advice. The coincidental circumstances of 1552 and 1560 certainly suggest that in both cases Smith advised Cecil on the exact valuation for the new coinage.

Further, "The Wages of a Roman Footsoldier," the treatise Smith wrote for Cecil in 1562, establishes his stature as a numismatist. Use of a document written a decade after events it is said to have influenced is not sound historical procedure. However, our knowledge of Smith's longtime interest in coins and of the memorandum he prepared on this subject in the autumn of 1549 does substantiate the contention that he was an expert at that time. Consideration of other possible candidates at mid-century leads to the conclusion that Smith was probably the only man with this specialized knowledge. The thematic parallels between A Discourse of the Commonweal of this Realm of England, Smith's treatise on economic theory, and "The Wages

13 Froude, History of England, 5, p. 250. Cites B.I. Harleian MS 660 for this treatise in Smith's hand. 
of a Roman Footsoldier," his treatise on coinage, indicate that Smith had formed the fundamentals of his economic thought by 1549.14

The basic lesson of both the Discourse and the "Footsoldiex" is that debasement of the coinage is harmful because it causes inflation and a depletion of the treasure of the realm. This premise was the foundation of Cecil's program to reform the coinage in 1552. The government's acknowledgment of self interest as a legitimate economic force to be harnessed for the state's benefit is a modern concept stated in the Discourse, at mid-century a novel idea found only in Smith's writing. It too was a fundamental part of cecil's restoration policy. Both the Discourse and government policy in 1552 reflect a positive philosophy, a constructive rather than restrictive approach to reform, which is unique in Commonwealth literature and novel in a period of traditionally repressive public policies. Both Smith's writing and Cecil's reforms are based upon a desire for improvement, a step toward the Commonwealth goal of merging the ideal and the real. Thus it can be proposed that Sir Thomas Smith's insistence that Edwardian financial problems could

${ }^{14}$ Mary Dewar discusses this correlation fully in her article "The Authorship of the 'Discourse of the Commonweal': its Authorship and Dating," Ec.H.R., 2nd ser., 19, 1966.

See Appendix II for synopsis of "The Wages of a Roman Footsoldier." 
be solved only by a restoration of the fineness of English currency did in fact determine the fiscal policy designed to curb inflation late in the reign and, in a larger sense, that the comprehensive and positive guidelines inherent in Smith's Discourse appear in Cecil's approach to both administrative and fiscal reform. 


\section{CONCLUSION}

The socio-economic conditions of the mid-sixteenth century generated a new approach to the articulation and remedy of contemporary problems. Outstanding amid a plethora of mid-Tudor Commonwealth literature was A Discourse of the Commonweal of this Realm of England, a sophisticated statement of economic theory made by a humanist scholarstatesman, Sir Thomas Smith. Although Smith's contribution to Edward's government was limited in his official role as King's Secretary, a greater impact may well have come unofficially through his friendship with sir William Cecil, also King's Secretary and a man of consequence on the Privy Council. Together Smith and Cecil set the valuation of Elizabeth's coinage in 1560 and it is probable that their contact during the previous decade resulted in Cecil's use of Smith's ideas in 1551-1552.

Cecil's personal attributes and the circumstances of his Secretaryship placed him in an effective position under Northumberland, a man who took advice and delegated responsibility to govern through the Council. Thus as Northumberland's key administrator, secretary Cecil could formulate and implement policy through the Privy Council.

Smith was a man of ideas with little talent for leadership. As secretary under Somerset his advice was 
ignored and his duties circumscribed. In consequence, he turned to the written word as an outlet for his thoughts. The background and career shared by Smith and Cecil combined to bring them together throughout Edward's reign and nurtured their relationship. At mid-century, their association probably led to the measures which initiated the reform of English finance. Together Smith and Cecil influenced the mid-Tudor Commonwealth in thought, word and deed. 
BIBLIOGRAPHY 


\section{PRIMARY SOURCES}

Manuscript Sources

British Library

Additional Manuscript 48047. Unpublished MS. "The Wages of a Roman Footsoldier" by Sir Thomas Smith.

Harleian Manuscript 6989. Letter from Sir Thomas Smith to Duchess of Somerset.

Cambridge University Library

Baker Manuscript 37. William Cecil's Instructions to Sir Thomas Smith, 1566.

State Papers, Edward VI, Volumes 10-15. Weikel microfilm.

Printed Sources

Historical Manuscripts Commission

Salisbury Manuscripts, Volume I.

Public Records Office

Acts of the Privy Council, Volumes II, III, IV.

Calendar of Patent Rolls, Edward VI, Volumes III, IV, V, VI.

Calendar of State Papers, Foreign Series, 15471553 .

Calendar of State Papers, Spanish, Volume $\mathrm{x}$. 
Adair, E. R. The Sources for the History of the Council in the 16th and 17th Centuries. London: Society for Promoting Christian Knowledge, 1924.

Archbold, W. A. J. "A Manuscript Treatise on the Coinage by John Pryse, 1553." Ec.H.R., XIII (1898), pp. 709-11.

Baldwin, James F. The King's Council in England During the Middle Ages. 1913; rpt. Oxford: Oxford University Press, 1965.

Baumer, Franklin V. The Early Tudor Theory of Kingship. New Haven: Yale University Press, 1940.

Beer, Barrett L. Northumberland. The Kent State University Press, 1973.

Beer, Barrett L., and Sybil M. Jack, eds. "The Letters of William, Lord Paget of Beaudesert 1547-63." Camden Miscellany; 4 th ser., XXV. London: The Royal Historical Society, 1974 .

Bindoff, S. T. Tudor England. Harmondsworth: Penguin Books, 1950 .

Bindoff, S. T., and Joel Hurstfield, eds. Elizabethan Government and Society. London: University of London, 1961 .

Braddock, Robert C. "The Rewards of office-Holding in Tudor England." Journal of British Studies, XIV; No. 2 (May 1975), pp. 29-47.

Brenner, Y. S. "The Inflation of Prices in Early Sixteenth Century England." Ec.H.R., 2nd ser., XIV (1961-62), pp. 29-47.

- The Price Revolution Reconsidered: A Reply." Ec.H.R., 2nd ser., XVIII (1965), pp. 392-6.

Bush, Michael L. The Government Policy of Protector Somerset. London: Edward Arnold (Pubs.) Ltd., 1975.

Caspari, Fritz. Humanism and the Social Order in Tudor England. Chicago: University of Chicago Press, 1954.

Challis, C. E. "Currency and Economy in Mid-Tudor England." Ec.H.R., 2nd ser., XXV (May 1972), pp. 313-22. 
- "The Debasement of the Coinage 1542-1551."

Ec.H.R., 2nd ser., XX, No. 3 (1967), pp. 44l-66.

- The Tudor Coinage. Manchester: Manchester

University Press, 1978.

Chaloner, W. H., and R. C. Richardson, eds. British

Economic and Social History: A Bibliographical Guide.

Manchester: Manchester University Press, 1976.

Clifford, Arthur, ed. The State Papers and Letters of Sir Ralph Sadler. Edinburgh: Archibald Constable \& Co., 1809 .

Cunningham, w. The Growth of English Industry and Commerce. 1910 ; rpt. New York: Augustus Kelley, 1968.

Dewar, Mary. "The Authorship of the 'Discourse of the Commonweal.'" Ec.H.R., 2nd ser., XIX (1966), pp. 388400 .

"The Memorandum 'For Understanding the

Exchange': its Authorship and Dating." Ec.H.R., 2nd ser., XVII (1965), pp. 476-87.

1964.

- Sir Thomas Smith. London: The Athlone Press,

Dictionary of National Biography. London: Oxford Universi.ty Press, 1917.

Dietz, Frederick C. English Government Finance. Urbana: University of Illinois Press, 1921 .

"Finances of Edward VI and Mary." Smith College studies in History, 52 , No.2 (1918), pp. 61102 .

Dunham, William H., and Stanley Pargellis, eds. Complaint and Reform in England 1436-1714. New York: Oxford University Press, 1938 .

Elton, Geoffrey R. England Under the Tudors. London: Methuen \& Co., Ltd., 1955.

"The Problems and Significance of Administrative History in the Tudor Period." Journal of British Studies, IV, No. 2 (1965), pp. 18-28.

- Reform and Reformation: England 1509-1558.

London: Edward Arnold (Pubs.) Ltd., 1977. 
- Reform and Renewal. Cambridge: Cambridge University Press, 1973.

- Studies in Tudor and Stuart Politics and Government. Cambridge: Cambridge University Press, 1974 .

- The Tudor Constitution. Cambridge: Cambridge University Press, 1968.

- "The Tudor Revolution: A Reply." Past and Present, 29 (1964), pp. 26-49.

- The Tudor Revolution in Government. Cambridge: Cambridge University Press, 1969.

Evans, F. M. The Principal Secretary of State. New York: Barnes and Noble, 1923.

Feaveryear, A. E. The Pound Sterling. London: Oxford University Press, 1931.

Ferguson, Arthur B. The Articulate Citizen and the English Renaissance. Durham: Duke University Press, 1965.

"'Renaissance Realism' in the Commonwealth Literature of Early Tudor England." Journal of the History of Ideas, XVI (1955), pp. 287-305.

- "The Tudor Commonwealth and the sense of Change." Journal of British Studies, III, No. I (1963), pp. $11-35$.

Froude, James A. History of England. Vol. 5. 1862-70; rpt. New York: AMS Press, 1969.

Fusfeld, Daniel R. "On the Authorship and Dating of 'For the Understanding of the Exchange.'" Ec.H.R., 2nd ser., $\mathrm{XX}$ (1967), pp. 145-50.

Gould, J. D. The Great Debasement. Oxford: Clarendon Press, 1970 .

"The Price Revolution Reconsidered." Ec.H.R., 2nd ser., XVII, No. 2 (1964-66), pp. 249-66.

Heal, Felicity. "The Tudors and Church Lands: Economic Problems of the Bishopric of Ely During the Sixteenth Century." Ec.H.R., 2nd ser., 26 (1973), pp. 198-217. 
Henderson, John Patrick. Winchester, A Tudor Time-Server." University 1969.
"Sir William Paulet, Marquess of Diss. St. Louis

Hexter, J. H. The Vision of Politics on the Eve of the Reformation: More, Machievelli and Seyssel. New York: Basic Books, 1973.

- "Thomas More: On the Margins of Modernity." Journal of British Studies, I (1960), pp. 20-37.

Hoak, Dale E. The King's Council in the Reign of Edward VI. Cambridge: Cambridge University Press, 1976.

Holderness, B. A. Pre-Industrial England: Economy and Society, 1500-1750. Totowa, New Jersey: Rowman \& Littlefield, 1976 .

Hudson, w. S. John Ponet, Advocate of Iimited Monarchy. Chicago: University of Chicago Press, 1942.

Hurstfield, Joel. "Corruption and Reform Under Edward VI and Mary." English Historical Review, 68 (1953), pp. $22-36$.

Jones, H. M. "Origins of the Colonial Idea in England." Proceedings of the American Philosophical Society, 85 , No. 5, pp. 448-65.

Jones, Whitney R. D. The Mudor Commonwealth 1529-1559. Iondon: The Athlone Press, 1970.

Jordan, Wilbur K. Edward VI: The Threshold of Power. Cambridge, Mass.: The Belknap Press, 1970.

- Edward VI, the Young King: London: Allen \& Unwin, $1 \overline{968 .}$

Kelley, Donald R. Francois Hotman: A Revolutionary's Ordeal. Princeton: Princeton University Press, 1973.

Lehmberg, Stanford E. Sir Walter Mildmay and Tudor Government. Austin: University of Texas, 1964.

Lovejoy, Arthur. The Great Chain of Being. Cambridge: Harvard University Press, 1950.

McConica, J. K. English Humanists and Reformation Politics Under Henry VIII and Edward VI. Oxford: Clarendon Press, 1965. 
Nichols, John G., ed. Literary Remains of Edward VI. New York: Burt Franklin, 1857.

- "Some Additions to the Biographies of Sir John Cheke and Sir Thomas Smith." Archaeologia, No. 38 (1860), pp. 98-127.

Outhwaite, R. B. Inflation in Tudor and Stuart England. London: Macmillan, 1969.

Pevsner, Nikolaus. "Hill Hall." Architectural Review, May 1955, pp. 307-09.

Pollard, A. F. England Under Protector Somerset. 1900; rpt. New York: Russell \& Russell, 1966.

- The History of England 1547-1603. London: Longmans, Green \& Co., 1923.

Quinn, David. "Sir Thomas Smith and the Beginning of English Colonial Theory." Proceedings of the American Philosophical Society, 89, No. 4 (1945), pp. 543-60.

Raab, Felix. The English Face of Machievelli. London: Routledge and Kegan Paul, 1964.

Ramsey, Peter, ed. The Price Revolution in Sixteenth Century England. London: Methuen, 1971.

- Tudor Economic Problems. London: Victor Gollancz, Ltd., 1966.

Read, Conyers. Lord Burghley and Queen Elizabeth. London: Jonathan Cape, 1960 .

- Mr. Secretary and Queen Elizabeth. New York: Alfred knopf, 1955.

Richardson, W. C. History of the Court of Augmentations 1536-1554. Baton Rouge: Louisiana State University Press, 1961 .

- Tudor Chamber Administration 1485-1547.

Baton

Rouge: Louisiana State University Press, 1952.

, ed. The Report of the Royal Commission of 1552. Morgantown: West Virginia University Library, 1974.

Roover, Raymond De. "On the Authorship and Dating of 'For the Understanding of the Exchange." Ec.H.R., 2nd ser., $\mathrm{xx}$ (1967), pp. 150-52. 
Russel1, Conrad. "Arguments for Religious Unity in England 1530-1650." Journal of Ecclesiastical History, 18 (1967), pp. 201-26.

Smith, Brian. Policy Making in British Government. Totowa, New Jersey: Rowman \& Littlefield, 1976.

Smith, Sir Thomas. De Republica Anglorum: The Maner of Government or Policie of the Realm of England. Ed. L. Alston. Cambridge: Cambridge University Press, 1906 .

- A Discourse of the Commonweal of this Realm of England. Ed. Mary Dewar. Charlottesville: The University of Virginia Press, 1969.

Strype, John. "The Iife of Sir John Cheke." Works. Vol. 24. Oxford: Clarendon Press, 1821.

- "The Life of the Learned Sir Thomas Smith." Works. Vol. 25. Oxford: Clarendon Press, 1820.

Summerson, John. Architecture in Britain. London: Penguin Books, 1958 .

Tawney, R. H., and Eileen Power. Tudor Economic Documents. London: Longmans, Green \& Co., 1924.

Tytler, P. F. England Under the Reigns of Edward the Sixth and Mary. London: Richard Bentley, 1839 .

Zeeveld, W. G. Foundations of Tudor Policy. London: Methuen \& Co., Ltd., 1948 . 
APPENDICES 


\section{APPENDIX I}

DISCOURSE EXCERPT $1576^{1}$

The following quotation from the Discourse is part of the section revised by Smith in 1576. Although it reflects no new thought, its later date precludes associating it with the reforms of 1552. Its content is interesting, however, for the Doctor's plan is exactly that used by cecil.

Knight: Still, you would have us return from our old path when we strayed; but now all the mastery is in the devising of the means how.

Doctor: You put me now to a great matter and exceeding my simple wit; that would be devised by the great wise heads of council or of the parliament or of some picked number of learned and wise men chosen of them and put together to consult of this matter a great space. I have percase waded further than my part was, to speak so far and to tell that the things must once be done.

It is dangerous to meddle in the King's matters and specially if it may have any likelihood to diminish his profit.

Knight: True it is, if a man did speak it in place where it should do harm indeed and to that intent.

Doctor: I do not so but all to the best purpose I take God to record - and to the King's Highness most profit, honor and safety at length; yet some percase will say that pertains not to me to study

${ }^{1}$ Sir Thomas Smith, A Discourse of the Commonweal of this Realm of England, ed. Mary Dewar (Charlottesville: The University of Virginia Press, 1969), pp. 107-09. 
for. Yet I am a subject and I owe him not only obedience but also the obsequy I can, either in deed or in devise, and therefore I will put the case thus. Grant the King should make proclamation that, after Michaelmas next coming, there should be no money current within this realm but only after the old rate and that every man should bring in his new coin to the King's mint and there to have bills; that for every ten shillings of new coin brought in, the king give to them, between Michaelmas and Christmas next after or some such time, an angel noble either in good gold or in good silver of the old value, viz., ten groats to the ounce of silver and six angels to the ounce of gold. 


\section{APPENDIX II}

SYNOPSIS OF

"THE WAGES OF A ROMAN FOOTSOLDIER"

By

Sir Thomas Smith

Smith's title is deceptive for this is primarily a treatise on the history of coinage. In determining the first use of currency for the payment of military wages, Smith traces a numismatic chronology, estimates the value of coins by their weight and metallic content, and offers a means of comparing old standards through the ages to the year 1562. Sixteenth century scholars were keenly interested in classical studies and Smith's treatise reflects this humanistic awareness of contemporary links with Greece and Rome.

A more general interest in history dictated Smith's appreciation of "comparing the doings and the sequels of the doings of comon wealthes" as a means of understanding contemporary problems. 2 Smith would agree that experience is often the best teacher. Knowledge of past

${ }^{1}$ B.I. Addit. MS. 48047 , ff. 138-165.

${ }^{2}$ B.L. Addit. MS. 48047 , f. 140 . 
"inconvenience" is useful

so that if they which were another of first attempts wherof the evil had followed, known of the sequel of the like attempt in other comon wealthes before and marked it well, they would peradventure have been most against their own doing. 3

According to Smith, "the first paying of wages to the soldiers was 350 or some 346 years after the building of Rome." 4 The first coins were made of brass, were called asses, and were funded by the levy of a special tax. Perhaps at the time of the Carthaginian Wars, commerce required that coins be lighter and finer, dictating the shift to silver coins. 5

Alluding to recent Tudor history, Srnith explains that the costs of war often place great financial stress upon governments.

So that it may well appear that other common wealthes have been also constrained to do the same which ours hath done to enhance their coin and to abase their standard at urgent rations of war or want of money. But they were most happy that could reform again their coin unto the old estate for the abasing of the standard is a manifest token of the decaie of the state and the continual undoing of it. For as they money abaseth, so do all things This states Smith's fundamental belief in debasement as a

$$
\begin{aligned}
& \text { 3B.L. Addit. MS. } 48047 \text {, f. } 140 \text {. } \\
& { }^{4} \text { B.I. Addit. MS. } 48047 \text {, f. } 141 \text {. } \\
& { }^{5} \text { B.I. Addit. MS. } 48047 \text {, f. } 162 \text {. } \\
& { }^{6} \text { B.L. Addit. MS. } 48047 \text {, f. } 146 \text {. }
\end{aligned}
$$


cause of inflation. The integrity of the coin as a reflection of the integrity of the government is a theme which runs through all of Smith's writing. Debasement of the coin diminishes its authority and makes men lose faith in the "prince."

Classical coins were valued according to their metallic content, yet the human element affected their exchange. Smith takes pains to show that soldiers were skeptical of new coins and would accept them only when they were assured of their "real" or purchasing value as equivalent to the old coins. ${ }^{7}$ This was true in classical times and continued to be so until Smith's era when intrinsic value was influenced by purchasing power and skepticism about the new coins drove the finer old coins out for circulation.

Smith's knowledge of metrology is evident in his various conversion tables for brass, silver and gold money. Showing that the ounce had been a standard unit of weight from Roman times, Smith offers intricate tables by which values can be determined through the centuries. 8

Smith believed firmly that the proportional value of silver to gold was universal and unalterable in nature

7 B.L. Addit. MS. 48047 , f. 162 .

${ }^{8}$ B.I. Addit. MS. 48047 , ff. $147,148,159,160$. 
and that it stood at 12 to 1.9 Respect for this "law of nature" should dictate monetary values placed on coins. He shows that princes who alter this fixed proportion suffer. The only remedy is a return to the old standard. It is probable that this theory dates from Smith's post1549 study of Jean Bodin concerning the influence of the New World shipments of precious metals to Europe. Therefore, this section of the Footsoldier relates to the revised section of the Discourse which dates from 1576. Smith was also led to this conclusion by his study of the history of coins. He correctly demonstrates that the ounce and the dram (or Greek drachma, the equivalent of six obols) can be used for conversion purposes in both English and classical currencies.

Then it was evident that their first sestertius was equal in goodness and weight to our first English pennie. And the denarius should have been equal to our first English groat if we had coined then any groates. And who would think that in 51 (?) Edwardi or 3 Henri primj, for my books do differ in the naming of them, there should rise a prince in this isle so farr distant from Rome and so many years after the coining of silver and gold in Rome in the most barbarous time and most ful of ignorance that was at that time, and when the Romans them selves had clene lost and abandoned that kind of money, that should simply and so directly establish in his realm that standard in goodness and weight which the old Romans did first establish in their time. 10

9.1. Addit. MS. 48047, ff. 158, 164. Smith was mistaken in this belief.

10 B. L. Addit. MS. 48047 . 
As he does in the Discourse, Smith reveals his understanding of both monetary principles and human nature in the Footsoldier. The only remedy for the "decaie" of the realm is a return to fine coins, minted in silver and gold on a standard near 12 to 1 . New fine coins will attract men to the mints if they are assured of a profit when they turn in the old currency. Il

Smith's broad acquaintance with classical and contemporary authors from Thucidydes, Pliny and Cicero to Agricola, Bude and Erasmus enabled him to buttress his history with their works. He points out that the errors in Bude's De Asse et Partibus (1514), a treatise on classical weights and measures, did not come from "rascal writers" but accidentally from inexact translations of ancient authors. ${ }^{12}$ He also uses an historical context when discussing the Roman practice of rewarding veterans (20 years of service) with land and position, establishing them as "coloni" or ruling officers in conquered settlements. In this manner, Roman soldiers' retirement was paid for by the spoils of war, Roman customs extended throughout the Empire, and permanent settlements given authoritative rule. The example of such reward for service, Smith points out, was "encouragement of all others to the

$$
\begin{aligned}
& 11_{\text {B.I. Addit. MS. } 48047, \text { f. } 151 .} \\
& 12_{\text {B.I. Addit. MS. } 48047 \text {, f. } 149 .}
\end{aligned}
$$


like boldness and attempt." 13

A few personal anecdotes explain when and how Smith came to his interest in soldiers and coins. As a small boy he first saw men in uniforms with

white and pied coats. I asked my father what they were and what they had a day. He answered they were soldiers and were hired to fight against the Frenchmen or Scots and he said they had $v$ or $v j s$ a day for they could not live under. 14

Later, when he was a student at Cambridge, Smith received a coin dating from the reign of claudius and inscribed "De Brittan."15 "This was found by one plowing beside the windmill in Saffron Walden," Smith's native village. 16 Upon receipt of the coin, Smith took it to a goldsmith to have it examined for weight and fineness. On this evidence he determined that it was "no counterfeit" and added it to the collection which he describes in his treatise.

Smith's study of coins thus dates from his Cambridge days, and was based on analysis of actual Roman specimens, as well as on the "olde authors." The expertise with which he wrote in 1562 did not come from a new hobby, but from a lifelong study upon which he also drew in 1549

13.L. Addit: MS. 48047 , f. 165 .

${ }^{14}$ B.L. Addit. MS. 48047 , f. 162 .

15 B.L. Addit. MS. 48047 , f. 156 .

16 B.I. Addit. MS. 48047 . 
when writing the Discourse.

In connection with the exchange of ideas between Smith and Cecil, it should be noted that one of the three extant manuscripts is entitled: "A Treatise on the Money of the Romans dedicated to Sir William Cecil, Kt., Chief Secretary to the Queen's Majesty."17 Even further evidence that this work was prepared for cecil comes from a reference in the text. Describing the "great store of those ancient coins both in silver, brass and gold when I was in Cambridge, which you have seen," Smith is referring to one of the many occasions when, as students and as statesmen, he and cecil had been together in Cambridge. 18 Cecil shared Smith's interest in coins and had requested that his friend put his specialized knowledge in written form.

What should be Smith's concluding statement comes somewhat before the final chapter, but summarizes the purpose of the book.

We have run now a hard large race. But I trust I have made all plain and clear as I have gone. So that we may come more easily to the summing up of our attempt to declare what the wages of the Roman soldier was and not only but what was

17 This manuscript is currently in possession of the Society of Antiquaries in London. See Mary Dewar, Sir Thomas Smith (London: Oxford University Press, 1964), p. 86 .

18 B.L. Addit. MS. 48047 , f. 155 . 
the true value of any sum spoken of in old authors and declared by the Roman method of coining that is Denarius or Asses or Sestertii. 19

Smith's treatise is complicated and its subject matter has been described as "remote." 20 However, as a history of money and as a means through which historical comparisons could provide understanding of sixteenth century problems, it has practical value.

19. L. Addit. MS. 48047 , f. 161.

${ }^{20}$ Mary Dewar, "The Authorship of the 'Discourse of the Commonweal," "Ec.H.R., 2nd ser., xix (1966), p. 390 . 
EXHIBIT A

\section{SAMPLE PAGE}

THE WAGES OF A ROMAN FOOTSOLDIER ${ }^{1}$

by

Sir Thomas Smith

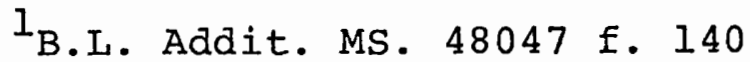




\section{ng}

\section{0}

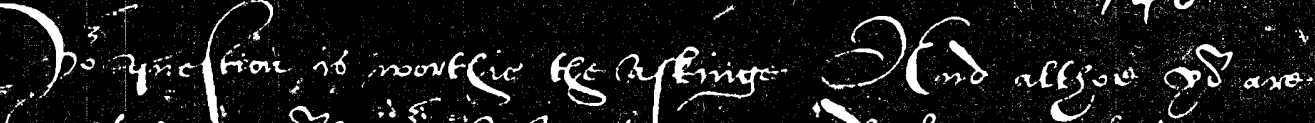

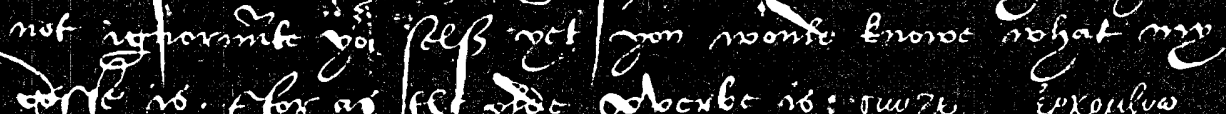

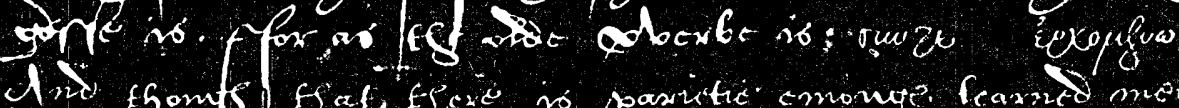

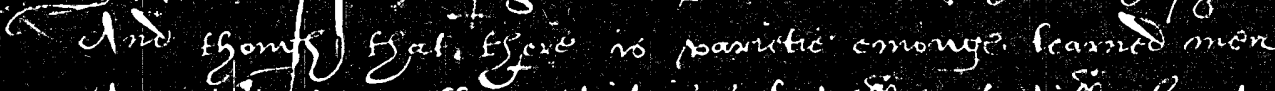

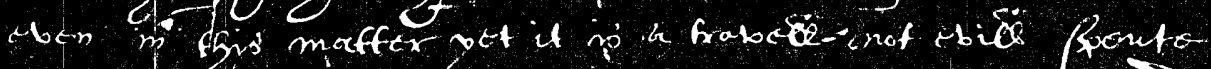

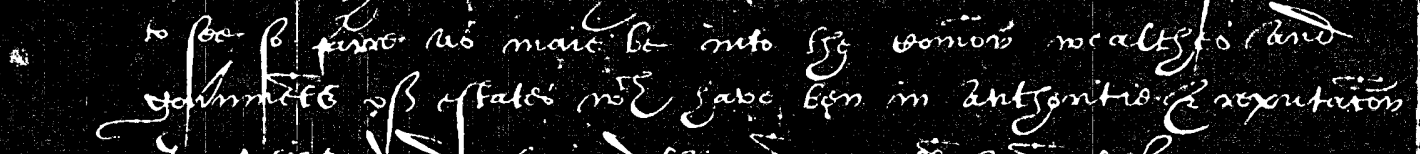

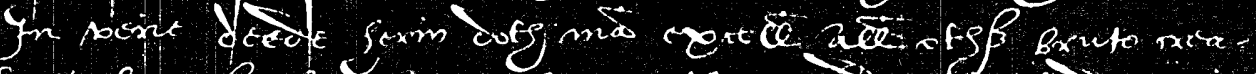

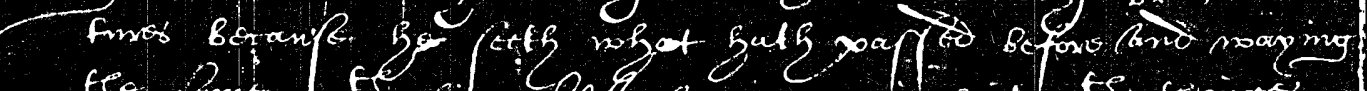

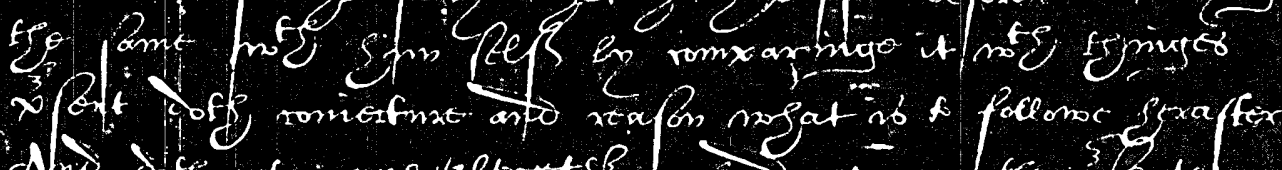

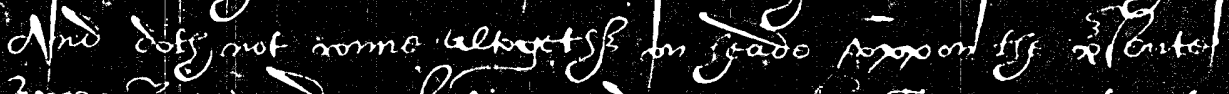

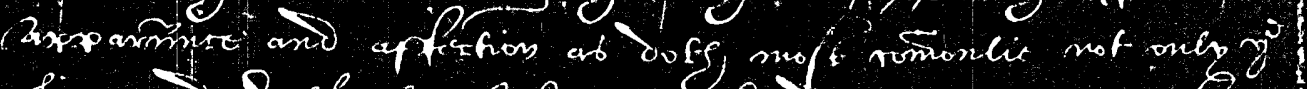

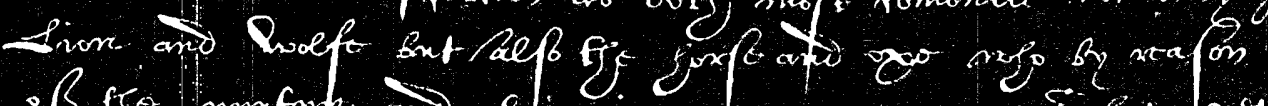

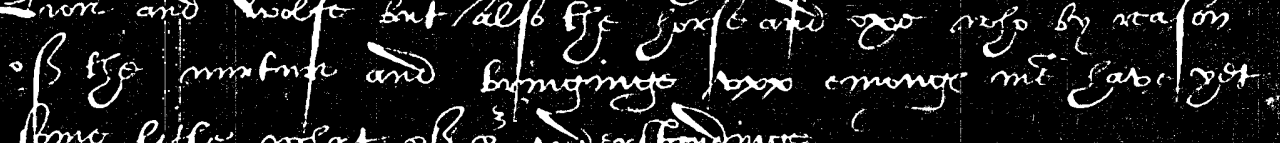

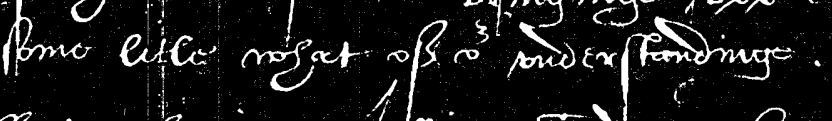

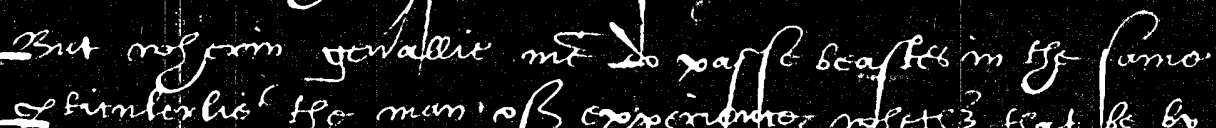

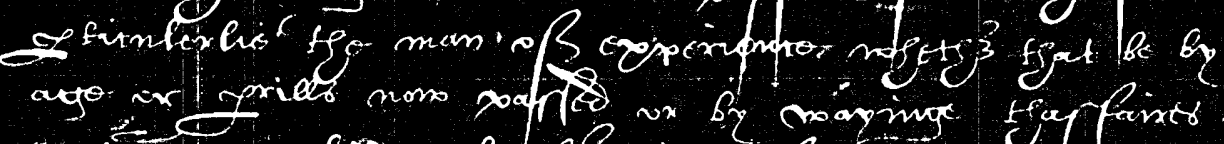

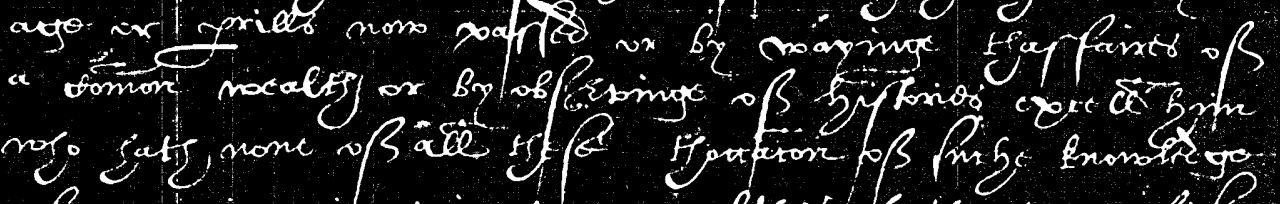

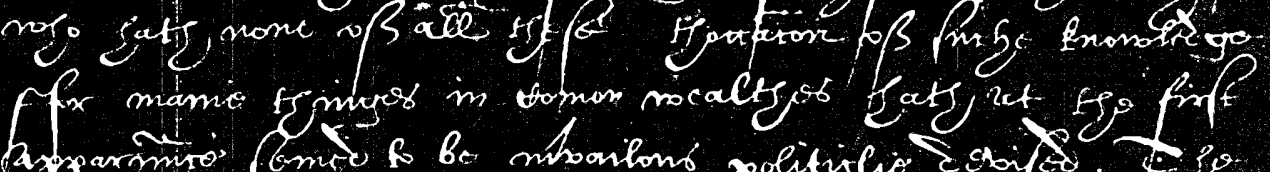

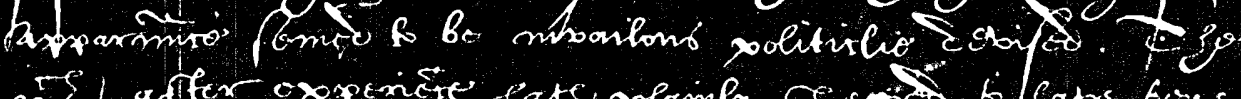

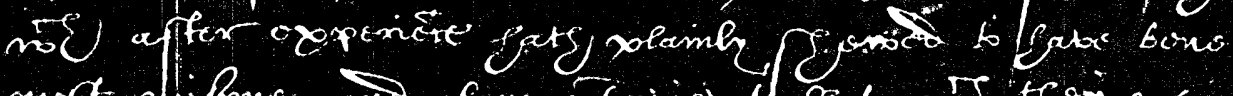

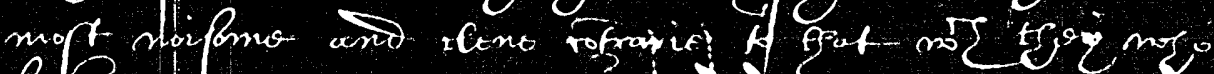

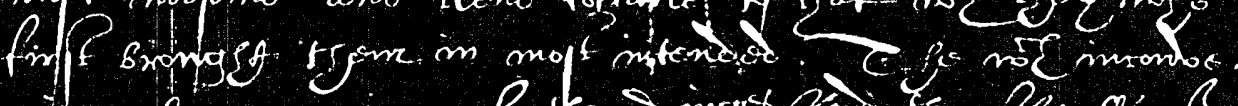

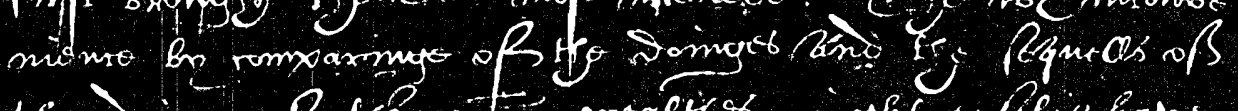

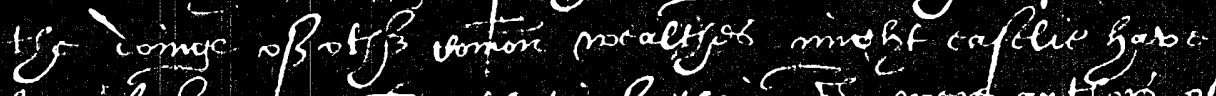

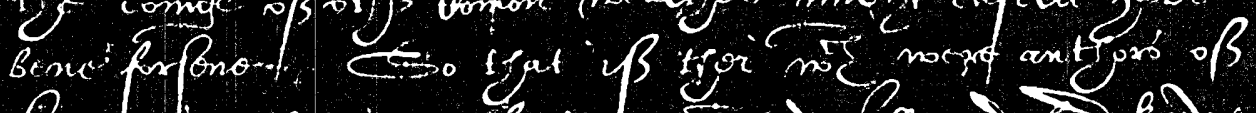

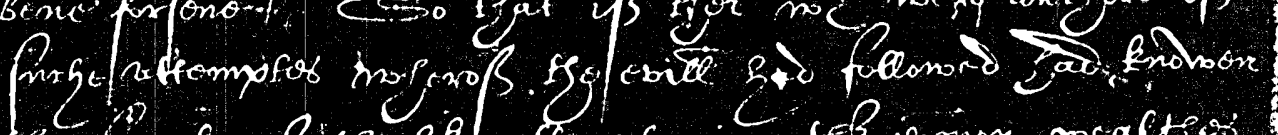

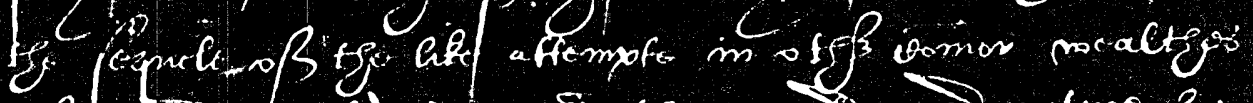

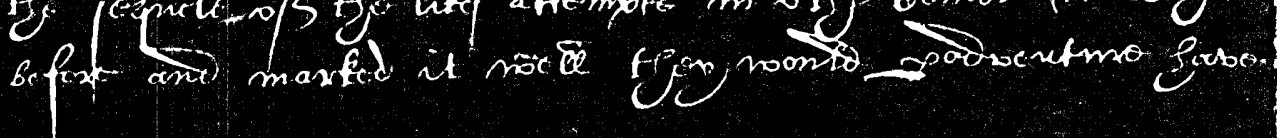


REVENUE COURT COMMISSION OF MARCH $23,1552^{1}$

Commission to Sir Thomas Darcy, K.G., lord Darcye of Chich, lord chamberlain of the king's house, Thomas bishop of Norwich, Sir John Gates, knight, vice-chamberlain, Sir William Petre, knight, one of the two Principal Secretaries, Sir Robert Bowes, knight, Sir Thomas Wrothe, knight, one of the four Chief Gentlemen of the Privy Chamber, Sir Richard Cotton, knight, Sir Walter Mildmay, knight, one of the two General Surveyors of Augmentations and Revenues, and John Gosnolde, esquire, solicitor in that court, (although of late in the time of the king's father, courts were erected for the governance of the lands of the crown and officers in them endowed with good fees the lands are neither so profitably ordered nor the revenues so duly answered as was meant and is expedient for the king's "royll affares, which require greate treasoures") to be especial commissioners for the survey of his rents and revenues "and principally the state of suche latter courtes as have bene erected for the revenues in the tyme of our said father of noble memorye."

${ }^{1}$ Cal. Pat. Rolls, Edw. VI, IV, p. 353. 